\title{
LA VIOLENCIA DE GÉNERO Y LOS CONTORNOS DE LA CRIMINALIDAD POR ODIO EN LA JURISPRUDENCIA SOBRE LA AGRAVANTE DEL ART. 22.4 CP:
}

\section{¿UN SALTO HACIA LO DESCONOCIDO?}

\author{
Iñigo Gordon Benito \\ Investigador en Derecho Penal \\ Cátedra UNESCO de Derechos Humanos y Poderes Públicos \\ Universidad del País Vasco (UPV/EHU) ${ }^{1}$
}

Title: Gender-based violence and the borders of hate crimes in the jurisprudence applying the aggravating circumstance under art. 22.4 Criminal Code: ¿A leap into the unknown?

Sumario: 1. Introducción y objeto de estudio. 2. Metodología. 3. Agravante por motivos discriminatorios del art. 22.4 CP: notas previas a su estudio jurisprudencial. 3.1. Derecho penal antidiscriminatorio y espacio aplicativo de la agravante dentro de la especificidad de los delitos de odio. 3.2. ¿Obligatoriedad de diseño de una punta de lanza común en la legislación penal española? El género en la agravante como opción político-criminal. 3.3. Búsqueda de equilibrio en un escenario legal tan nuevo como desconocido. 3.4. Derecho penal comparado: particularidades e incidencia de la agravante en algunos sistemas de justicia penal del common law. 4. Estudio jurisprudencial. 4.1. Algunos datos sobre la agravación de delitos comunes en España. 4.1.1. Sentencias condenatorias o confirmatorias de condena dentro del primer trienio aplicativo de referencia (2015-2018). 4.1.2. Actualización de datos (2018-2020). 4.2. Evolución y estado de madurez del fundamento de la agravante. 4.2.1. Situación que precede a los primeros pronunciamientos del Tribunal Supremo. 4.2.2. Tribunal Supremo y turbación interpretativa. 4.2.3. Reflexiones y posicionamiento. 5. Conclusiones. Referencias bibliografícas.

1 La presente contribución ha sido financiada por la Cátedra UNESCO de Derechos Humanos y Poderes Públicos de la Universidad del País Vasco-Euskal Herriko Unibertsitatea (UPV/EHU). 
Resumen: Han transcurrido algo más de cinco años desde que la violencia de género se instalara, todo indica que para quedarse, en los dominios de los delitos de odio. Este estudio sigue los primeros compases aplicativos de la agravante por motivos discriminatorios de género (art. 22.4 Criminal Code) y realiza un análisis exhaustivo de sentencias condenatorias en torno al precepto, lo que permitirá contextualizar y evaluar la operatividad que ha desplegado el "género" en comparación con el resto de categorías protegidas. Asimismo, un examen caso por caso servirá para recabar información esencial (perfil de agresor y víctima, fecha y lugar de comisión del delito, y categorías delictivas agravadas) sobre la fenomenología aplicativa de la agravante, así como para avanzar en el marco teórico de su fundamentación.

Palabras clave: Delitos de odio, art. 22.4, circunstancia agravante genérica, género, jurisprudencia.

Abstract: A little more than five years have gone since gender-based violence was established in the realm of hate crimes, and there is every reason to believe that this will continue to be the case. This study follows the initial steps in the application of the aggravating circumstance of gender-based discrimination (art. 22.4 Criminal Code) and carries out an exhaustive analysis of convictions on the basis of that provision. This will make it possible to contextualize and evaluate the effectiveness of "gender» in comparison with other protected categories. Likewise, a case-by-case analysis will help to gather essential information (victim and offender profiles, date and place of the offence, and aggravated crime categories) on the phenomenology of the application of such aggravating factor, as well as to advance in the theoretical framework of its rationale.

Key words: Hate crimes, art. 22.4, generic aggravating circumstance, gender, case-law.

\section{Introducción y objeto de estudio}

Los delitos de odio representan una supra-categoría marco que, aunque innominada en su plasmación legal, se halla a día de hoy tan instalada en el discurso público que cala con facilidad en la sociedad. Todo ello con el consabido riesgo de vaciar la expresión o desfigurar sus contornos. En abstracto, los delitos de odio tienden a asociarse con cualquier infracción penal en la que la víctima es seleccionada por alguna suerte de vinculación, incluso supuesta, a ciertas categorías marco (p.ej.: raza, etnia, religión, etc.), que aun siendo aparentemente neutras conectan en realidad con ciertos sujetos o grupos diana con síntomas de vulnerabilidad o fragilizados (p.ej.: negros, gitanos, homosexuales, etc.). Su tutela penal no puede ni debe desvincularse de la experiencia sociohistórica de victimización en una determinada sociedad, siendo un estado 
de agravio objetivo sobre el que el autor busque o sea consciente de que sus actos conllevan intersubjetivamente una reválida de tal recuerdo vivo —o sensación de desprotección- en el momento de los hechos.

Uno de los esfuerzos más notables e influyentes por ofrecer una definición de referencia sobre delitos de odio nacía en el seno de la Organización para la Seguridad y la Cooperación en Europa (OSCE) en el año 2005. Se trataba de una definición similar a la ya expuesta ${ }^{2}$, que servía como intento armonizador de mínimos para que los Estados participantes la hicieran suya y la adecuasen a su realidad nacional. Ese mismo año los Estados también se comprometían a "prevenir y combatir todas las formas de violencia de género perpetradas contra mujeres y niñas» (apdo. 1 de la Decisión del Consejo Ministerial de la OSCE núm. 15/2005, de 6 de diciembre de 2005³). Tal compromiso, aun sin contener una alusión expresa, se entiende como una muestra más de los esfuerzos de esta organización por que los Estados se planteasen abrir el arco de tutela penal a otras categorías protegidas en materia de delitos de odio. Si bien durante los primeros pasos legislativos para combatir los delitos de odio prevalecieron las figuras delictivas con una marcada preocupación antixenófoba (p.ej.: racismo, antisemitismo, prejuicios étnicos y/o nacionales), la OSCE invitaba a los Estados a que no descuidasen y valorasen la necesidad de incorporar otras modalidades prejuiciosas (p.ej.: discapacidad, orientación sexual o género) a sus respectivas legislaciones ${ }^{4}$. Según la OSCE, en la base de toda decisión sobre la expansión de causas protegidas debían ponderarse diferentes factores. El primero tenía que ver con que la selección de la víctima lo fuera por características identitarias inalterables (p.ej.: una discapacidad) o fundamentales (p.ej.: la religión),

2 Según una traducción de esta definición que recoge la Fiscalía General del Estado (2019), se entiende por delito de odio "toda infracción penal, incluidas las infracciones contra las personas y la propiedad, cuando la víctima, el lugar o el objetivo de la infracción son seleccionados a causa de su conexión, relación, afiliación, apoyo o pertenencia real o percibida pertenencia a un grupo que pueda estar basado en la raza, origen nacional o étnico, el idioma, el color, la religión, la edad, la minusvalía física o mental, la orientación sexual u otros factores similares, ya sean reales o supuestos». Véase: OSCE/ ODIHR, Combating hate crimes in the OSCE region, OSCE/ODIHR, Varsovia, 2005, p. 12, https://www.osce.org/files/f/documents/2/3/16405.pdf (último acceso: 13/09/2020); Fiscalía General del Estado, Circular 7/2019, sobre pautas para interpretar los delitos de odio tipificados en el art. 510 CP, FGE, Madrid, 2019, p. 68, https://www.fiscal.es/documents/20142/ f42d355a-ce0b-3652-562c-53fe07d6ccc6 (último acceso: 13/09/2020).

3 OSCE/ODIHR, Decisión del Consejo Ministerial de la OSCE núm. 15/2005 sobre la prevención y combate de la violencia contra la mujer, de 6 de diciembre de 2005 (MC.DEC/15/05), OSCE/ODIHR, Liubliana, 2005, https://www.osce.org/files/f/documents/b/7/70204.pdf (último acceso: 13/09/2020).

4 Ahora bien, la OSCE no pretende dar a entender que necesariamente deban realizarse modificaciones legislativas para lograr la uniformidad más absoluta entre legislaciones penales. Más bien trata de promover un enfoque común para facilitar la recogida de datos que puedan ser de interés y obtener así información estadística comparable entre Estados. OSCE/ODIHR, Combating hate crimes...op. cit., pp. 10-12. 
que conformasen un sentido de pertenencia a un grupo. El segundo factor era el relativo al contexto social e histórico de un lugar. Por ello, atendiendo a las dinámicas de discriminación opresivas (vigentes y pasadas), se debía colegir la necesidad de reforzar la protección del colectivo en cuestión dentro del marco de una realidad nacional. Finalmente, como tercer y último factor, la OSCE hacía hincapié en valorar adecuadamente las implicaciones prácticas que derivasen de la incorporación de una u otra categoría para los operadores jurídicos (p.ej.: la dificultad probatoria respecto a una categoría que no presenta rasgos observables evidentes) ${ }^{5}$.

Pues bien, no sin ciertas dudas de que el último factor apuntado haya sido debidamente atendido caso por caso, el género se iría incorporando como categoría protegida en las distintas legislaciones nacionales sobre delitos de odio. Por lo demás, de entre los textos internacionales que han ido consolidando la idea de dar cabida al género en el marco de los delitos de odio y dentro de las legislaciones domésticas, parece destacar el Convenio del Consejo de Europa sobre prevención y lucha contra la violencia contra la mujer y la violencia doméstica, hecho en Estambul el 11 de mayo de 2011 (en adelante, «Convenio de Estambul») ${ }^{6}$.

A día de hoy, de lo que no cabe duda es que la OSCE acoge sin ambages que la agresión a una persona por contravenir creencias generalizadas o cánones sociales sobre comportamientos ligados (y supeditados) al sexo constituye un delito de odio por prejuicios de género. Y de ahí que esta organización estime imprescindible que el género reciba una atención «sistemática» en la persecución de los delitos de odio ${ }^{7}$.

5 OSCE/ODIHR, Hate crime laws. A practical guide, OSCE/ODIHR, Varsovia, 2009, pp. 38-39, https:/www.osce.org/files/f/documents/3/e/36426.pdf (último acceso: 13/09/2020).

6 Este instrumento está en vigor desde el 1 de agosto de 2014 en España. Tanto por la notoriedad que ha adquirido este tratado internacional (p.ej.: el Pacto de Estado contra la Violencia de Género de 2017 aspiraba a valorar la necesidad de adecuar nuestra legislación en materia de género al Convenio de Estambul), así como por las constantes remisiones de doctrina y jurisprudencia a su texto a fin de situar el origen de la confluencia entre los delitos de odio y las razones de género en nuestro Código penal, nos remitimos aquí al epígrafe «3.2. ¿Obligatoriedad de diseño de una punta de lanza común en la legislación penal española? El género en la agravante como opción político-criminal» infra.

7 OSCE/ODIHR, Prosecuting hate crimes. A practical guide, OSCE/ODIHR, Varsovia, 2014, pp. 32-33, https:/www.osce.org/files/f/documents/0/0/124532.pdf (último acceso: 13/09/2020). También existe una traducción no oficial al castellano como resultado de la colaboración entre el Ministerio de Asuntos Exteriores y Cooperación, la Fiscalía General del Estado y la Secretaría General de Inmigración y Emigración del Ministerio de Empleo y Seguridad Social. Nótese que el entrecomillado en el texto sobre el carácter sistemático que debe caracterizar la atención que se dispense al género obedece a que, sorprendentemente, este matiz se obvió en dicha traducción. Por tanto, su alusión proviene del texto original en inglés ("gender should, therefore, be systematically considered when prosecuting hate crimes ») e interesa resaltar este aspecto que, aunque en apariencia menor, ganará en relevancia en la medida en que el estudio en general vaya también ganando profundidad. 
En términos generales, el estudio que sigue se centrará en realizar un análisis crítico respecto a la operatividad que ha merecido la agravante por motivos discriminatorios de género del art. $22.4 \mathrm{CP}^{8}$ en el ámbito judicial español. Esta circunstancia modificativa de la responsabilidad penal es la materialización de una tendencia legislativa ${ }^{9}$ que busca ofrecer respuestas a la criminalidad por odio dentro de un articulado, como el español, que no ha escatimado en medios para intervenir en materia penal antidiscriminatoria ${ }^{10}$.

En concreto, el estudio se articula sobre tres grandes ejes. En primer lugar, se realizará una aproximación a la temática de la agravación por motivos discriminatorios en general y al art. $22.4 \mathrm{CP}$ en particular. Se abordará su génesis en el marco del Derecho penal antidiscriminatorio, explicando su sentido y alcance dentro de la categoría más específica de los delitos de odio. Después se analizará si existía o no la obligación internacional de introducir las razones de género dentro de tal agravante en el ordenamiento jurídico español, lo cual constituye un punto de partida que conviene afianzar a fin de evitar equívocos ya de por sí muy extendidos. Tras ello, se apuntarán los retos que suscitaba - y que todavía hoy suscita- la incorporación en el año 2015 del género como categoría protegida dentro de la agravante del art. $22.4 \mathrm{CP}$. En buena medida, ese escenario legal ha condicionado el recorrido aplicativo de la agravante en

Versión traducida: OSCE/ODIHR, La persecución penal de los delitos de odio. Guía práctica, Ministerio de Empleo y Seguridad Social. Subdirección General de Información Administrativa y Publicaciones, Madrid, 2016, pp. 44-45, https://cpage.mpr.gob.es/ producto/la-persecucion-penal-de-los-delitos-de-odio-2/ (último acceso: 13/09/2020).

8 El art. 22 CP, según la modificación efectuada por Ley Orgánica 1/2015, de 30 de marzo, por la que se modifica la Ley Orgánica 10/1995, de 23 de noviembre, del Código penal, reza lo siguiente: «Son circunstancias agravantes: (...) $4^{\mathrm{a}}$ ) Cometer el delito por motivos racistas, antisemitas u otra clase de discriminación referente a la ideología, religión o creencias de la víctima, la etnia, raza o nación a la que pertenezca, su sexo, orientación o identidad sexual, razones de género, la enfermedad que padezca o su discapacidad».

9 En concreto, la tendencia de incorporar una técnica agravatoria para infracciones penales ya previstas en el Código penal y que estuviesen motivadas por prejuicios de muy diferente signo (p.ej.: raciales, homófobos, etc.). En suma, este modelo legislativo fija un máximo o mínimo adicional a la responsabilidad penal de un individuo por la comisión de un delito común (p.ej.: asesinato, agresión sexual, robo, etc.). Si el delito de partida puede serlo

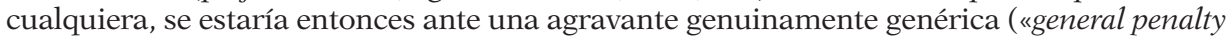
enhancement»), de lo contrario sería una agravante más o menos limitada en su alcance («specific penalty enhancement»). La agravante del art. 22.4 CP vigente se corresponde con la primera subcategoría referida. En general, este modelo («penalty enhancement model») se opone al de infracción penal sustantiva («substantive offence model»), donde el elemento prejuicioso que agrava es elemento constituyente del tipo (p.ej.: el delito de discurso de odio punible del art. $510 \mathrm{CP}$ ). OSCE/ODIHR, Hate crime laws...op. cit., pp. 32-37.

10 Con gran detalle, para un recorrido histórico-legislativo sobre las diferentes figuras antixenófobas y antidiscriminatorias que se han sucedido hasta las actualmente contenidas en la normativa penal, véase LANDA GoROSTIZA, J.M., La política criminal contra la xenofobia y las tendencias expansionistas del Derecho penal (a la vez una propuesta interpretativa de la "normativa antidiscriminatoria» del CP 1995 y un análisis crítico de la incipiente jurisprudencia), Comares, Granada, 2001, passim. 
la praxis judicial de estos últimos años. Finalmente, nos asomaremos al derecho penal comparado de algunos sistemas de justicia penal del common law. Y ello porque, además de ser la agravación de delitos comunes una técnica importada de la cultura jurídica anglosajona, el fundamento y la incidencia de su aplicación más allá de nuestras fronteras servirá como contrapunto al estudio jurisprudencial que sigue.

En segundo lugar, se abordará propiamente el examen jurisprudencial de la agravante del art. $22.4 \mathrm{CP}$, atendiendo a las resoluciones condenatorias (o confirmatorias de condena) dictadas a su alrededor. La búsqueda de tales resoluciones será exhaustiva, siendo analizadas todas aquellas que devuelvan las bases de datos consultadas ${ }^{11}$. El examen jurisprudencial se realizará, a su vez, en dos tiempos. En un primer momento se aspira a ofrecer una visión global de todas las condenas recaídas en las que algún delito haya sido agravado por motivos discriminatorios desde la entrada en vigor del Código penal (mayo de 1996) y hasta agotar los tres primeros años de aplicación del género dentro de la agravante por motivos discriminatorios (1 de julio de 2015-1 de julio de 2018). De esta forma se pone en contexto al lector sobre la operatividad real de la agravante antes y después de la incorporación del género como categoría protegida tras la Ley Orgánica 1/2015, de 30 de marzo, por la que se modifica la Ley Orgánica 10/1995, de 23 de noviembre, del Código penal (en adelante, LO 1/2015). Posteriormente se traerá a colación la información clave (perfil de agresor y víctima, fecha y lugar de comisión del delito, y categorías delictivas agravadas) que ha podido extraerse de las sentencias condenatorias (o confirmatorias de condena) en las que conste alguna agravación por razones de género del art. $22.4 \mathrm{CP}$. El marco temporal fijado comprende del 1 de julio de 2015 al 1 de julio de 2020, lo que equivale a los cinco primeros años de actividad judicial en torno a la agravante por razones de género del art. $22.4 \mathrm{CP}$.

$\mathrm{Al}$ margen de lo recurrente de su apreciación, la agravación de delitos por las razones de género previstas en el art. $22.4 \mathrm{CP}$ ha proporcionado un campo más que fértil para su análisis. Ello se debe tanto a los numerosos recursos planteados por las partes que han cuestionado su aplicación (o la falta de la misma), como por la profundidad y disparidad de razonamientos empleados para que así sea. Esto enlaza con la fundamentación de la agravante, cuestión que será examinada en todas y cada una de las resoluciones condenatorias recaídas. De hecho, que el legislador haya incorporado el género en el art. $22.4 \mathrm{CP}$, per se, no aclara si se opta por un fundamento equiparable al que ha salvado la constitucionalidad para los delitos de violencia de género. Esto es, considerar que la legitimidad de la agravación conecta con conductas que, según claves interpretativas más objetivas, se encuadrarían en un contexto de dominación machista. Ello no es baladí, ya que si se asumiese esta

11 En detalle, véase el apartado «II. Metodología» que se desarrollará infra. 
premisa $^{12}$ y la conducta se pre-configurara como objetivable, enlazaría mejor con uno de los modelos de entendimiento de los delitos de odio, el "discriminatory selection model» ${ }^{13}$, hoy por hoy minoritario en la doctrina española. O lo que es lo mismo, que sea suficiente con probar que la víctima fue seleccionada por razón de ser mujer (elemento de acción selectiva). Si bien la puesta en marcha pudo estar accionada por la motivación de autor (machista) ${ }^{14}$, interesaría corroborar un contexto de plena consciencia del impacto de ese actuar contra el colectivo mujer ${ }^{15}$, más allá de la víctima concreta ${ }^{16}$. En cambio, si el ánimo subjetivo de autor fuera el que finalmente guiara la aplicación de las razones de

12 Por ejemplo, la STSJ de Canarias 7/2017, de 26 de junio, ya avanzaba o sacaba a colación este extremo, aunque no sin ciertas cautelas: «el término "género» [en el art. 22.4 $\mathrm{CP}$ ] parece que debe interpretarse en consonancia con todo el corpus normativo promulgado a partir de la entrada en vigor de la Ley Orgánica 1/2004, de 28 de diciembre (...)» (FJ 4).

13 Así lo planteó también DíAz López, que incluso antes de la reforma penal apuntaba ya a la ligazón o puente que algunos pretendían establecer entre la agravante del art. 22.4 $\mathrm{CP}$ y los delitos de violencia de género a fin de consolidar el modelo de selección discriminatoria para la agravante al que este autor parece oponerse. Véase: DíAz LópEz, J.A., «Una agravante por motivos discriminatorios referidos al género de la víctima», Revista Derecho Penal, Núm. 54, Bogotá, 2016, p. 13; DíAz LóPEz, J.A., El odio discriminatorio como agravante penal. Sentido y alcance del artículo 22.4 ${ }^{a}$ CP, Aranzadi, Pamplona, 2013, p. 143.

14 De hecho, el modelo opuesto al de selección discriminatoria, el motivacional ( [racial] animus model»), obligaría a realizar una investigación del móvil o ánimo que movió la conducta de autor en clave estrictamente subjetiva. Para la obra fundacional de esta división dicotómica de las legislaciones sobre los delitos de odio, sea expresa o catalogable por inferencia, véase LAWrence, F.M., Punishing hate. Bias crimes under American law, Harvard University Press, Cambridge, 1999.

15 Según LANDA GOROSTIZA, para la aplicación de la agravante lo esencial será la comprobación de que el autor era consciente de que su actuar iba a ser comprendido, tanto por el grupo diana, como por la sociedad en su conjunto, como una amenaza implícita e intersubjetiva dirigida, como mínimo, hacia un espectro significativo de los sujetos que presenten el mismo elemento en común que determinó la selección de la víctima. LANDA Gorostiza, J.M., Los delitos de odio. Artículos 510 y 22.4 ${ }^{\circ}$ CP 1995, Tirant lo Blanch, Valencia, 2018, p. 124.

16 Esto parece que podría no estar ocurriendo en todas aquellas conductas delictivas que se producen sin testigos y en la intimidad del hogar. Si bien es dudoso que en todo lo que engloba la violencia de género, en cuanto a su gravedad o fenomenología, el agresor sea siempre consciente de estar contribuyendo con su acto a un contexto de dominación patriarcal, recuérdese que ello no es óbice para la aplicación de la doctrina más actualizada alrededor del delito de maltrato ocasional (art. $153 \mathrm{CP}$ ). De forma clara lo recoge el Tribunal Supremo, entre otras, en la STS 677/2018, de 20 de diciembre: «Basta constatar la vinculación del comportamiento, del modo concreto de actuar, con esos añejos y superados patrones culturales, aunque el autor no los comparta explícitamente, aunque no se sea totalmente consciente de ello o aunque su comportamiento general con su cónyuge, o excónyuge o mujer con la que está o ha estado vinculado afectivamente, esté regido por unos parámetros correctos de trato de igual a igual» (FJ 3; resaltado añadido). Por tanto, debemos cerciorarnos si la agravante por motivos discriminatorios de género del art. 22.4 $\mathrm{CP}$ engancha con esta lógica o conserva un sentido aplicativo propio. Por esta última opción parece inclinarse, por ejemplo, MAQUEDA ABREU, quien indica que la agravante demanda una exégesis alejada de la experiencia acumulada en relación con las previsiones de la Ley Orgánica 1/2004, de 28 de diciembre, de Medidas de Protección Integral contra la Violencia de Género (en adelante, LO 1/2004). MAQuedA ABREU, M.L., «El hábito de 
género dentro de la agravante del art. $22.4 \mathrm{CP}$, ello entonaría mejor con la interpretación culpabilística dominante en el resto de categorías protegidas por el art. 22.4 CP, pero se alejaría de la fuerza especial y del mayor daño que desprenden unos hechos, como sucede con los tipos penales con marca de género (p.ej.: arts. 148.4, 153.1, 171.4 y 172.2 CP) de nuestra normativa penal.

Tras todo lo anterior, se expondrá una breve reflexión acerca de la opción interpretativa que entiendo como la más adecuada para guiar esta confluencia de supra-categorías delictivas (delitos de odio y violencia de género), que hasta hace bien poco discurrían por caminos separados ${ }^{17}$. En concreto, cobrará especial interés determinar si la lectura en clave primordialmente subjetivista que se ha adueñado de la agravante por otros motivos discriminatorios (p.ej.: motivos racistas, homófobos, ideológicos, etc.) ha calado también en la aplicabilidad de la agravante por razones de género, o si por el contrario las razones de género pudieran contribuir de alguna forma a objetivar el campo de los delitos de odio (es decir, un posible efecto contagio). La información obtenida en el estudio jurisprudencial, así como aquella otra que quedará apuntada en el apartado de derecho comparado, servirán seguro para afianzar argumentos a la hora de optar por una u otra dirección. Por último, se realizarán algunas consideraciones conclusivas a modo de recapitulación final.

\section{Metodología}

El estudio jurisprudencial tendrá por objeto examinar todos aquellos pronunciamientos condenatorios (o confirmatorios de condena) que se obtengan como resultado de una búsqueda exhaustiva en cuatro bases de datos o portales jurídicos (Cendoj, La Ley Digital, Tirant Online y Aranzadi Westlaw). Todos ellos, en la medida que integran servicios o recursos electrónicos cuya función es la devolución de resoluciones judiciales allí

legislar sin ton ni son. Una lectura feminista de la reforma penal de 2015», Cuadernos de Política Criminal, Núm. 118, 2016, p. 16.

17 Si bien es cierto que son categorías que han avanzado por caminos separados hasta acabar confluyendo en la legislación, no es menos cierto que hay entre ellas algunas similitudes estructurales. Por ejemplo, existen tipos penales con marca de discriminación o puramente antidiscriminatorios (p.ej.: arts. 511 y $512 \mathrm{CP}$ ), como también existen delitos con marca de género o puramente de género (p.ej.: arts. 148.4, 153.1, 171.4 y 172.2 CP). Además, tanto en el marco del Derecho penal antidiscriminatorio como en el del Derecho penal sexuado parece evidente que aflora un debate fuertemente ideologizado. De ahí que, en ocasiones, se cuestionen las singularidades de ciertas realidades delictivas (p.ej.: delitos de odio y violencia machista o de género, como categorías diferenciadas de los tipos penales antidiscriminatorios y de la violencia doméstica o intrafamiliar). Para un mejor entendimiento del Derecho penal antidiscriminatorio en general y de los delitos de odio en particular, véase «3.1. Derecho penal antidiscriminatorio y espacio aplicativo de la agravante dentro de la especificidad de los delitos de odio" infra. 
alojadas, ofrecen una imagen que no debe ser entendida en términos absolutos, aunque sí en términos estimativos. Es decir, los datos que se obtengan deberán considerarse como indicador muy autorizado sobre la realidad judicial. Aun con las limitaciones referidas, este apartado aspira a ser completo en sí mismo en cuanto a sentencias condenatorias (o confirmatorias de condena) identificadas. Ello será así en lo concerniente a todas aquellas dictadas desde la entrada en vigor del actual Código penal de 1995 (mayo de 1996) y hasta el 1 de julio de 2020 como fecha de cierre. Lo anterior se realizará con especial celo a la hora de identificar y seguir el iter procesal caso a caso.

Una vez contrastadas entre sí todas las resoluciones condenatorias (o confirmatorias de condena) devueltas por La Ley Digital ${ }^{18}$, Tirant Online ${ }^{19}$, Aranzadi Westlaw ${ }^{20}$ y Cendoj ${ }^{21}$, una lectura minuciosa de las mismas ha

18 En cuanto a La Ley Digital, primero se ha buscado el Código penal de 1995 [LA LEY 3996/1995] en el apartado Códigos LA LEY. Tras ello, permitiéndose realizar una selección artículo por artículo, se ha acudido directamente al art. 22.4 CP. Dicho precepto, a su vez, habilita la opción de acceder a toda la jurisprudencia asociada al mismo. Finalmente, tras limitar la búsqueda a la jurisdicción penal y al ámbito temporal estipulado (25 de mayo de 1996-1 de julio de 2020), el sistema devuelve doscientas sesenta resoluciones [última comprobación realizada el 6 de agosto de 2020]. Posteriormente, la lectura individualizada de cada una de ellas ha permitido identificar aquellas resoluciones condenatorias (o confirmatorias de condena) en las que se haya estimado concurrente la agravación por cualquier motivo discriminatorio de entre los recogidos en el art. $22.4 \mathrm{CP}$.

19 En cuanto a Tirant Online, se ha acudido a la sección de Jurisprudencia para a continuación seleccionar el art. 22 dentro del CP/1995 [TOL223.185] en el campo «relacionado con artículo/norma». Tras la búsqueda, se ha realizado un filtrado de resultados. Primero se ha limitado a aquellos relacionados con la jurisdicción penal. En segundo lugar, en la opción de búsqueda denominada «elementos del delito», se ha seleccionado "circunstancias agravantes" y se ha realizado una nueva comprobación de resultados. Acotando todavía más, de entre las opciones que contempla el buscador en cuanto a circunstancias agravantes se ha marcado la relativa a "agravante por motivos racistas, antisemitas u otra clase de discriminación» y la de "desprecio de género". La búsqueda, esta vez, devuelve doscientos sesenta y cinco documentos encontrados [última comprobación realizada el 6 de agosto de 2020], manteniendo el criterio temporal de búsqueda ya referido ( 25 de mayo de 1996-1 de julio de 2020). Nuevamente, la lectura documento a documento ha permitido ir extrayendo las resoluciones condenatorias (o confirmatorias de condena) con apreciación del art. 22.4 CP.

20 En cuanto a Aranzadi Westlaw, acudimos a la sección Jurisprudencia y, dentro de ella, a «buscar jurisprudencia sobre una norma». Tras seleccionar el CP/1995 [RCL 1995 3170], acto seguido se introduce el art. 22 CP en el nuevo buscador. Posteriormente se circunscribe la búsqueda de los resultados obtenidos al "área penal» y al periodo temporal de interés (25 de mayo de 1996-1 de julio de 2020). A partir de aquí, se ha optado por realizar búsquedas aleatorias mediante el uso de términos específicos (p.ej.: art. 22.4, género, discriminación, racismo, raza, etnia, motivos discriminatorios, etc.). También se han realizado búsquedas mediante combinaciones muy variadas de tales términos. Tras cada comprobación se ha examinado el listado de documentos devueltos y se han identificado las sentencias condenatorias (o confirmatorias de condena) que estiman aplicable la agravante del art. $22.4 \mathrm{CP}$.

21 En cuanto a Cendoj, más allá de atenernos a la jurisdicción penal y al ámbito temporal estipulado (25 de mayo de 1996-1 de julio de 2020), las búsquedas jurisprudenciales se han realizado introduciendo términos específicos (p.ej.: art. 22.4, género, discriminación, 
permitido cribar y extraer aquellos datos que son de interés. A efectos del presente estudio, los datos a identificar (o, en muchos casos, a inferir) de tales pronunciamientos variarán en función de la categoría protegida del art. 22.4 CP que nos ocupe en cada resolución analizada. De esta forma, diferenciaremos entre todas aquellas infracciones penales cometidas por características identitarias que sean diferentes a la del género (p.ej.: raza, etnia, religión, etc.), y aquellas otras que se hayan cometido precisamente por razones de género.

En relación a las primeras, nos ceñiremos a indicar la prevalencia de aparición una vez analizadas las diferentes infracciones penales que contengan las sentencias analizadas. Además, ciertas categorías marco que tienen dimensiones diferentes pero que suelen operar paralelamente (p.ej.: raza o etnia) serán referenciadas en sub-realidades de victimización diferenciadas (p.ej.: discriminación étnico-racial hacia negros, árabes, asiáticos, gitanos o latinos) y no como un todo indisoluble. También se opta por facilitar el desglose más minucioso de otras categorías, como pueda ser la de la discriminación por orientación sexual (p.ej.: gay o lesbiana).

Aunque la motivación que subyace al acto pueda resultar, en ocasiones, confusa (p.ej.: racismo, inmigración o xenofobia), o no se sepa si existe alguna motivación dominante, o si se trata de una victimización múltiple (p.ej.: agresión sexual porque la víctima era negra y, a causa de su discapacidad, le era imposible valerse por sí misma), se respetará la categorización que han establecido los jueces y tribunales siempre que así lo indiquen y no se haga alusión directa a alguna de las que radican legalmente recogidas (p.ej.: la discriminación por "formas de entender la vida" de la víctima, si bien el art. 22.4 CP alude a "creencias» de la víctima). Si no queda expresamente recogida cuál es la categoría protegida en el caso concreto o surgen dudas al respecto (p.ej.: la expresión «moro de mierda» puede enlazar con la pertenencia percibida a la etnia magrebí, con independencia de que una persona sea o no arabófona, pero también con cualquier persona que profese la religión islámica), será de una lectura entre líneas de la sentencia lo que ayude a determinar la incardinación del caso en una u otra categoría. Si aun así esto último no fuera posible, se recogerán tantas categorías como posibles causas de la agresión consten referenciadas o sean inferibles (p.ej.: etnia: magrebí/raza: árabe/religión: islámica). Por tanto, no debe olvidarse que la prevalencia de aparición de cada categoría es el resultado de haber simplificado en exceso un ejercicio complejo y, muchas veces, basado en la inferencia de lo contenido — sea poco o mucho- en los

racismo, raza, etnia, motivos discriminatorios, etc.) y realizando cruces o combinaciones aleatorias entre ellos. Tras cada comprobación se ha examinado el listado de documentos devueltos y se han identificado las sentencias condenatorias (o confirmatorias de condena) que estiman aplicable la agravante del art. 22.4 CP. 
fallos judiciales. En caso de resultar totalmente imposible de determinar la categoría en cuestión (p.ej.: cuando una sentencia de una instancia superior da por reproducidos unos hechos probados y no ha sido posible acceder a revisar los mismos), se aludirá a "[categoría] sin determinar o no evidente».

En relación con aquellos pronunciamientos condenatorios (o confirmatorios de condena) que lo hayan sido exclusivamente por razones de género, además de lo anterior, es preciso apuntar que su análisis se desdoblará en dos tramos temporales. El primero será el relativo al examen de los tres primeros años de aplicación de la agravante por razones de género del art. 22.4 CP (1 de julio de 2015-1 de julio de 2018) ${ }^{22}$, y el segundo en cambio el de los dos últimos (1 de julio de 2018-1 de julio de 2020). Las razones que motivan la decisión de dividir en dos tramos temporales el análisis de las sentencias recaídas son varias. La primera es que, a juzgar por los datos obtenidos, es aproximadamente al final del primer periodo cuando el género despunta y se convierte en la categoría protegida dentro del art. $22.4 \mathrm{CP}$ más empleada por jueces y tribunales de nuestro país. La segunda razón es que es también al final del primer periodo cuando el Tribunal Supremo tiene ocasión de pronunciarse sobre el fondo del recurso planteado acerca de la apreciación de la agravante que nos ocupa (STS 420/2018, de 25 de septiembre). En tercer lugar, se ha podido constatar que no son infrecuentes los casos en que, siendo revocada o apreciada la agravante, una instancia superior confirma o revoca su aplicación ${ }^{23}$. Por tanto, el primer periodo analizado permitirá observar el iter procesal completo de todos los casos, mientras que respecto al segundo periodo será más probable que puedan todavía dictarse pronunciamientos en uno u otro sentido por instancias superiores.

22 Por las similitudes y pretensiones compartidas en este punto, mención especial merece el estudio elaborado por el Grupo de Expertos/as en Violencia Doméstica y de Género del CGPJ (2018). Con todo, la metodología empleada difiere sustancialmente de la que aquí se plantea. Primero porque el estudio recién aludido abarca un periodo comprendido entre enero de 2016 y abril de 2018. Segundo porque su vaciado jurisprudencial se limita a la base de datos del Cendoj. Y, finalmente, porque se analiza una muestra de sentencias cuyo criterio de búsqueda no se ha limitado a la selección de aquellas con resultado de condena (o confirmatorias de condena) por delito agravado. Véase: CGPJ, Análisis de la aplicación de la agravante por razón de género en las sentencias dictadas entre 2016 y mayo de 2018, CGPJ, Madrid, 2018, http://www.poderjudicial.es/cgpj/es/Temas/Violencia-domestica-y-degenero/Grupos-de-expertos/Analisis-aplicacion-de-la-agravante-por-razon-de-genero-ensentencias-dictadas-entre-2016-y-mayo-de-2018 (último acceso: 13/09/2020).

23 Dos ejemplos bastarán: 1) la SAP de Badajoz 5/2018, de 5 de febrero, siendo primero confirmada por la STSJ de Extremadura 13/2018, de 16 de octubre, el Tribunal Supremo deja sin efecto la aplicación de la agravante mediante STS 223/2019, de 29 de abril (caso relativo al asesinato de Milena Gheorghe, temporera y excompañera sentimental del agresor, G.P., en el pantano de Alange en Badajoz); 2) la STSJ de Asturias 11/2018, de 3 de mayo, queda parcialmente anulada y se revoca la aplicación de la agravante por motivos discriminatorios de género mediante STS 584/2018, de 23 de noviembre (caso relativo al asesinato de Sonia Meléndez Mitre, gijonesa hostelera, a manos de su empleado y excompañero sentimental Abdou Ndiaye «Makelele»). 
Una vez definida la organización del análisis, de la lectura individualizada de cada una de las sentencias condenatorias (o confirmatorias de condena) en que conste algún delito agravado por las razones de género del art. 22.4 CP se extraerá la siguiente información de interés: fecha y lugar de comisión de los hechos, relación de la víctima con su agresor, edad de víctima y de autor, nacionalidad del autor, delito/s concreto/s agravado/s por el art. 22.4 CP y grado de ejecución alcanzado en los delitos más graves (asesinato y homicidio). En el caso de la edad de la víctima o del agresor, la ausencia de este dato se ha intentado suplir acudiendo a la repercusión mediática que haya podido tener el caso en particular, lo que sólo ha sido posible en los delitos más graves. De cualquier forma, se irá especificando el número de casos en que se ha podido conseguir ese dato fuera de las sentencias examinadas. Finalmente se tratará de identificar, a veces incluso a modo de mera conjetura en el caso de aquellos pronunciamientos más esquivos, dónde radica el fundamento de una tal agravación. Esto es, si su razón de ser se sitúa en la mayor reprochabilidad del móvil que mueve al autor a actuar, o en la mayor gravedad del injusto, sea en este último caso por un mayor injusto subjetivo del hecho o por el desvalor adicional del resultado. Todo lo anterior se complementará con algunos gráficos o figuras que, aunque en lugares del texto muy seleccionados, permitirán ofrecer una mayor claridad expositiva acerca de aquellos datos en los que se observe útil disponer de una representación gráfica.

\section{Agravante por motivos discriminatorios del art. 22.4 CP: notas previas a su estudio jurisprudencial}

\subsection{Derecho penal antidiscriminatorio y espacio aplicativo de la agravante dentro de la especificidad de los delitos de odio}

Ciertos comportamientos discriminatorios, por su especial gravedad, rigen todo un conjunto de preceptos que constituyen la normativa penal antidiscriminatoria española. A partir de 1990 y en las legislaciones penales europeas se amplían los móviles tradicionales de discriminación (raza, etnia, nacionalidad y/o religión) para contemplar una nueva y, hasta la fecha, desconocida oleada de motivos discriminatorios (ideología, sexo, orientación sexual, situación económico-social y/o estado físico). Se produce, dentro y fuera de España, un cambio de paradigma importante en términos de tutela penal. Esta expansión cuestionará, antes que nada, las designaciones más clásicas que se venían empleando para aludir a todos los tipos penales emparentados con el mismo fenómeno. Por ejemplo, nótese la alternancia habitual que existía entre «delito de racismo» o "delito de discriminación racial». Sin embargo, debido al nuevo horizonte aplicativo que se abría en la década de los noventa, el 
conjunto de este tipo de comportamientos pasa a referirse con el genérico «delitos de discriminación» ${ }^{24}$.

Entre las medidas del nuevo orden penal español se instala la técnica de la agravación genérica para delitos ya previstos en el Código penal (p.ej.: homicidio, lesiones, etc.), sin que el móvil del delito alterase su condición delictiva. Así, en esencia, se integra una categoría jurídica que, aunque nada clara en su plasmación legal, sería más tarde reivindicada por parte de la doctrina española bajo la archiconocida etiqueta de «delitos de odio» (o, preferiblemente, delitos de odio «sensu stricto»). Esta nueva categoría, de alguna forma extraña al derecho continental pero suficientemente asentada en los Estados Unidos, se enraizó en el ordenamiento penal español, primero con carácter de urgencia vía Ley Orgánica 4/1995, de 11 de mayo, de modificación del Código penal (art. $10.17 \mathrm{CP} / 1973)^{25} \mathrm{y}$, poco después, a través de la Ley Orgánica 10/1995, de 23 de noviembre, del Código penal (art. 22.4 CP/1995) ${ }^{26}$. Ello también reabrió una brecha con los delitos propiamente antidiscriminatorios, como lo eran aquellos tipos penales con una marca de discriminación consustancial (p.ej.: arts. 511 y $512 \mathrm{CP}$ ). A diferencia de lo que sucede en estos últimos, en los delitos de odio sensu stricto el prejuicio no es el que sostiene al hecho delictivo, sino que representa un gravamen sobre un hecho incuestionablemente delictivo ${ }^{27}$. Este y otros elementos clave de distanciación (p.ej.: el impacto sobre lo colectivo ${ }^{28}$ o la vulnerabilidad del

24 En detalle, véase BoRJa Jiménez, E., Violencia y criminalidad racista en Europa occidental: la respuesta del Derecho penal, Comares, Granada, 1999, pp. 246-273.

${ }_{25}$ La circunstancia agravante del art. $10.17 \mathrm{CP} / 1973$ apuntaba a «cometer cualquiera de los delitos contra las personas o el patrimonio por motivos racistas, antisemitas u otros referentes al origen étnico o nacional, o a la ideología, religión o creencias de la víctima».

26 Sobre la génesis legislativa y tramitación parlamentaria, véase: LANDA GoRostIZA, J.M., La política criminal...op. cit., pp. 180-185; LANDA GorostizA, J.M., Los delitos de odio...op. cit., pp. 117-121; DÍAZ LóPEZ, J.A., El odio discriminatorio...op. cit., pp. 27-59.

27 Sobre esta lógica, sirva con reparar a la OSCE, que entiende que tanto las conductas antidiscriminatorias como el discurso de odio son conceptos estrechamente relacionados con los delitos de odio, si bien no deben confundirse. Ambas realidades carecen de la seña de identidad de estos últimos, toda vez que la misma conducta, sin el componente prejuicioso, todavía puede ser perseguida penalmente. OSCE/ODIHR, Hate crime laws...op. cit., pp. 24-26.

28 Sobre este particular se pronuncia Bernal del Castillo. Según este autor, en los delitos propiamente discriminatorios la conducta lesiva se dirige contra la individualidad, por lo que la afectación al grupo o colectivo que engloba a la víctima en dimensiones simplemente se relega a un segundo plano. De otro lado, como se ha apuntado al comienzo de este trabajo, recuérdese que puede existir un impacto intersubjetivo que alcance dimensiones colectivas (agravación genérica) y un impacto frontalmente colectivo (tipo penal específico del discurso de odio) que marca distancias con el anterior. BERNAL DEL CASTILlo, J., «Política criminal en España y discriminación xenófoba: la centralidad de los delitos de provocación a la discriminación», Política Criminal: Revista Electrónica Semestral de Políticas Públicas en Materias Penales, Núm. 18, 2014, p. 382. 
colectivo ${ }^{29}$ como telón de fondo) ayudaron a moldear y comprender la especificidad $^{30}$ de la categoría de los delitos de odio. Esta especificidad, siguiendo a LAURENZO COPELLO, no debería nunca romper con la estructura basal que representa el Derecho antidiscriminatorio. De hecho, los delitos de odio se verían desprovistos de sentido si no los considerásemos como una forma más de ahondar en la marginación y exclusión social de ciertos grupos históricamente discriminados. Cualquier suerte de intervención penal que ignore esta premisa, aparte de desnaturalizar y descontextualizar la categoría, estaría apostando por una vía expansiva $-\mathrm{y}$, muchas veces, interesada o manipuladoraque afianza privilegios y posiciones de poder ${ }^{31}$. Sería, por tanto, una intervención ilegítima.

El principal escollo que interesa resaltar aquí es que, desde el momento en que la técnica de agravación general pasó a convivir con otras formas de tipificación penal de muy diferente signo (p.ej.: los tipos penales con la marca de discriminación, como los arts. 511 y 512

29 Ahora bien, DíAz LóPEz entiende que la noción de discriminación asociada a las motivaciones, como se deduce de la dicción literal del art. 22.4 CP (motivos discriminatorios), conectaría con un odio basado en la intolerancia. Una intolerancia entendida, a su vez, como creencias del sujeto que motivan su rechazo hacia personas que no comparten alguna de sus condiciones personales. Esas creencias son las que podrán llegar a exteriorizarse, precisamente, a través de un móvil (razón para la acción del sujeto). Por todo ello, este autor cree posible que los motivos discriminatorios del art. $22.4 \mathrm{CP}$ puedan estar apuntando a un sentido bidireccional de lo discriminatorio. De esta forma, la discriminación no se limitaría a la que padecen ciertos grupos históricamente expuestos a ella, sino que operaría también en dirección opuesta. Es decir, podría estar detrás de conductas delictivas llevadas a cabo por un sujeto perteneciente a un grupo históricamente desfavorecido o vulnerable y cuya víctima fuere, por poner un ejemplo extremo, un hombre blanco y heterosexual. En detalle, véase Díaz LóPEZ, J.A., Informe de delimitación conceptual en materia de delitos de odio, Secretaría General de Inmigración y Emigración, Observatorio Español del Racismo y la Xenofobia, Madrid, 2018, pp. 13-18, http://www.inclusion.gob.es/oberaxe/ficheros/documentos/InformeConceptualDelitosOdio.pdf (último acceso: 13/09/2020).

30 Aun así, es importante cuando menos reconocer que el debate conceptual entre delitos de odio y delitos de discriminación sigue, hasta cierto punto, enquistado cuando se trata de ofrecer una sistematización unívoca para los delitos de odio. Incluso, aunque minoritarias, persisten tiranteces de fondo. Por ejemplo, Tapia Ballesteros apunta a una necesaria coincidencia entre categorías, decantándose expresamente por la de delitos antidiscriminatorios por lo impreciso y equívoco de la otra denominación, que persiste como fuente inagotable de críticas. Aun así, esta autora también apunta a las bondades de que exista actualmente un reconocimiento supranacional y comparado de los «hate crimes». Véase: TAPIA BAllesteros, P., «Identificación de las víctimas de los delitos de odio: aproximación a algunos de los problemas que plantea esta categoría delictiva», en DE Hoyos SANCHO, M. (dir.), La víctima del delito y las últimas reformas procesales penales, Aranzadi, Pamplona, 2017, p. 360.

31 En detalle, véase: LaURenzo Copello, P., «La manipulación de los delitos de odio», en Portilla Contreras, G./Velásouez Velásouez, F. (dirs.), Un juez para la democracia: libro homenaje a Perfecto Andrés Ibáñez, Dykinson, Madrid, 2019, pp. 459-467; LaURENzo Copello, P., «Un ejemplo de derecho penal expansivo: los delitos de odio en la realidad judicial española», Revista de Derecho Penal, Núm. 26, 2018, pp. 250-253. 
$\mathrm{CP}$, o el delito de discurso de odio punible del art. $510 \mathrm{CP}$ ), también se estandarizó un mismo paraguas denominativo (esto es, los «delitos de odio»; o, mejor aún, los delitos de odio «sensu lato»). Esto servía, y de hecho así sigue siendo, para difuminar — si no directamente oscurecertoda diferencia entre técnicas de tipificación penal, siendo como hemos dicho sólo la técnica de agravación de tipos penales preexistentes la que definía la categoría de influencia anglosajona-norteamericana. La agravante del art. $22.4 \mathrm{CP}$, que proyecta un mayor reproche penal $-\mathrm{y}$ protección reforzada para las víctimas- sobre el tipo penal de referencia ( «penalty enhancement model»), convive en este sentido con el delito de discurso de odio punible (art. $510 \mathrm{CP}$ ). Este último representa el máximo exponente dentro del modelo legislativo que prioriza la incorporación de tipos penales especiales (esto es, aquellos que ya incorporan la marca discriminatoria) y que prescinden de tal desvalor por añadidura («substantive offence model»). Sin embargo, lo cierto es que el art. 510 CP tiende todavía hoy a invadir el sentido originario de los delitos de odio, que no es otro que el de ofrecer una respuesta penal agravada que neutralice el desvío que supone realizar unos actos delictivos por motivos prejuiciosos. A esta invasión contribuyó seguro el hecho de que el art. 22.4 CP viniera a ampliar sustancialmente el ámbito de aplicación que hasta entonces estaba limitado a los delitos contra las personas y el patrimonio (art. $10.17 \mathrm{CP} / 1973$ ). Desde la entrada en vigor del Código penal de 1995 la agravante del art. 22.4 CP alcanza, entre otros, a los delitos contra el honor (p.ej.: injurias y calumnias) o a los delitos contra la libertad (p.ej.: amenazas) ${ }^{32}$. Se tienden, por tanto, los primeros puentes de unión entre los delitos de pura expresión (discurso de odio punible) y los delitos materiales (delitos «de actos» de odio) a los que parecía limitarse el juego de la agravante ${ }^{33}$.

Actualmente, tanto el art. $22.4 \mathrm{CP}$ como el art. $510 \mathrm{CP}$ representan sendos cauces protectores de colectivos. Desde el año 2015, además, incorporan ambos las razones de género como categoría penalmente protegida. Esta categoría, a su vez, enlaza primordialmente con el colectivo mujer y con los estereotipos sociales que algunos individuos varones utilizan para perpetuar una visión más general y compartida sobre el concepto de feminidad. En definitiva, tanto el art. 22.4 CP como el art. $510 \mathrm{CP}$ recogen un elenco de categorías protegidas prácticamente

32 Así entendían que debía ser, y así lo demandaron en su momento, RodRíGuEz Devesa/Serrano Gómez. Véase Rodríguez Devesa, J.M./Serrano Gómez, A., Derecho penal español. Parte general (18 ${ }^{a}$ ed.), Dykinson, Madrid, 1995, p. 739.

33 Precisamente alguna línea doctrinal reciente viene apostando por incentivar el empleo de la agravante genérica (art. 22.4 CP) para absorber ciertos delitos de expresión como las injurias o calumnias. Esto es, tratar de vincular de forma preferente ciertas manifestaciones del discurso del odio punible a la agravante del art. 22.4 CP. Véase DíAZ LÓPEZ, J.A., «El art. 22.4 CP y la motivación discriminatoria online», en Miró LLINARES, F. (dir.), Cometer delitos en 140 caracteres. El Derecho penal ante el odio y la radicalización en Internet, Marcial Pons, Madrid, 2017, pp. 107-127. 
idéntico $^{34}$ que viste y sistematiza — si bien todavía parcialmente ${ }^{35}$ nuestra legislación penal en materia antidiscriminatoria. Como afirma LANDA GOROSTIZA, el art. $510 \mathrm{CP}$ debe interpretarse como cauce protector de colectivos vulnerables, sean minoritarios o, incluso, mayoritarios pero sin ser social ni políticamente dominantes. Sin embargo, sostiene, quizás la tutela de mayorías sería aconsejable se canalizase por la vía complementaria de la agravante genérica por motivos discriminatorios del art. $22.4 \mathrm{CP}^{36}$. Y es que siempre será diferente analizar el contenido declarativo de una manifestación que necesariamente impacte sobre lo grupal (art. $510 \mathrm{CP}$ ), que lanzar o mandar mensajes intersubjetivos con hechos (p.ej.: matar, violar, etc.) yendo contra miembros (p.ej.: una mujer) ${ }^{37}$ de un colectivo (p.ej.: colectivo mujer). Los delitos "de actos» de odio también tienen la capacidad de despertar decisiones resolutivas en terceros, siendo el acto en sí el vehículo del mensaje, si bien la fuerza de los hechos impide que se juegue la carta del derecho a la libertad de expresión, pues quedaría inoperante ${ }^{38}$. En cualquier caso, serán unos hechos puestos al trasluz de un contexto social muy concreto los que podrán ser capaces de generar tal fuerza comunicativa. El autor, aun dirigiendo sus actos hacia la víctima individual, contribuye a un caldo de cultivo que quizás y de forma tangencial no escape del todo a su conocimiento. Estaría reafirmándose en su posición social privilegiada mientras lanza un mensaje de advertencia - por ejemplo, en el caso del asesinato, suficientemente contundente- de lo que podría ocurrirle a todo miembro del colectivo de pertenencia de la víctima que tuviera la mala fortuna de cruzarse en su camino.

34 Si bien es notoria la apuesta por un criterio espejo de formulación, la agravante del art. 22.4 CP no contempla la «situación familiar» como categoría protegida que todavía se contiene en el art. $510 \mathrm{CP}$.

35 Cuesta entender por qué al delito de discriminación en el ámbito laboral (art. 314 $\mathrm{CP}$ ) o al delito de asociación ilícita que promueva o incite a la discriminación, el odio o la violencia (art. 515.4 CP) no se han incorporado las razones de género en su redacción típica tras la gran reforma penal de 2015. Véase Landa GorostizA, J.M., Los delitos de odio... op. cit., p. 46 (en concreto, véase nota al pie 80).

36 La OSCE reconoce que pueden cometerse delitos de odio contra miembros de un colectivo mayoritario, si bien recuerda que se trata de un instrumento político-criminal pensado para sostener a las comunidades más vulnerables, cuyos miembros son quienes soportan con mayor frecuencia e intensidad este tipo de delincuencia. OSCE/ODIHR, Hate crime laws...op. cit., pp. 20, 23 y 32.

37 En este sentido, sirva con traer a colación un pronunciamiento sobre violencia de género reciente del Tribunal Supremo que acerca ambas realidades: «En el fondo la agresión supone un mensaje de dominación intrínseca que no se expone externamente con palabras, pero sí con el gesto psicológico que lleva consigo el golpe, o el mal trato como aviso a la víctima de las consecuencias de su negativa a aceptar el rol de esa dominación» (STS 351/2019, de 9 de julio, FJ 3).

38 Landa Gorostiza, J.M., "El delito de odio del artículo 510 CP: propuesta de interpretación después de la reforma de 2015», Ponencia enmarcada en la segunda jornada (sesión de mañana) del Simposio Internacional sobre "Delitos de odio: estado de la cuestión desde una perspectiva comparada», Bilbao (Bizkaia Aretoa), 22 de septiembre de 2017. 


\section{2. ¿Obligatoriedad de diseño de una punta de lanza común en la legislación penal española? El género en la agravante como opción político-criminal}

En el año 2015 se materializa la apuesta político-criminal de recurrir a la agravación de la pena en caso de cometerse el delito en cuestión por razones de género ${ }^{39}$. Con todo, según qué pronunciamientos judiciales, ello fue así por lo — supuestamente- mandatado por el Convenio de Estambul. En efecto, algunas de las sentencias recaídas sitúan el origen de la agravante en esta afirmación errónea, puesto que el Convenio no exige ni directa ni indirectamente la creación de una agravante. Como veremos en breve, se ha venido sosteniendo un relato inexacto que, al parecer, resulta cómodo de abrazar. De hecho, el Convenio de Estambul no es tan siquiera un instrumento primariamente orientado a la tutela penal. Y ello es así en buena lógica, ya que existen contextos sociales y culturales muy diferentes entre aquellos países que han mostrado el compromiso de acatar sus disposiciones y adecuar sus legislaciones.

Sin embargo, numerosos posicionamientos judiciales no parecen dejar lugar a dudas. En la STS 565/2018, de 19 de noviembre (FJ 7), el Alto Tribunal a modo de consideración obiter dictum se refiere al Convenio de Estambul como germen de la introducción de la agravante. También

39 El primer Código penal aprobado en España, que data de 1822, contenía ya la referencia al "sexo femenino" como circunstancia agravante en delitos contra las personas (art. $106 \mathrm{CP} / 1822$ ). Tras el Código penal de 1848, se altera la redacción y pasa a agravarse la ejecución del hecho con «desprecio del respeto» que por su «sexo» mereciese el ofendido, si bien lejos de una equiparación entre sexos se seguía entendiendo como una referencia implícita al sexo femenino. En épocas más recientes, por LO 8/1983, de 25 de junio, de reforma urgente y parcial del Código penal, se suprime la alusión al «sexo» permitiendo aquilatar la recién instaurada perspectiva democrática. Según PRATS CANUT, si legalmente no se mantenía una agravación basada en el desprecio del hombre hacia la mujer, se lograrían ahuyentar los fantasmas de una implícita inferioridad de esta última. Por otro lado, si el fundamento de la agravante era más bien la diferencia de fuerza física entre sexos, la agravante de abuso de superioridad suplía ya por aquél entonces dicha empresa. Aunque la reforma urgente de 1995 no recuperó el «sexo» como categoría protegida (art. 10.17 CP/1973), el principio de igualdad entre sexos acabaría por inspirar la nueva agravante por motivos discriminatorios (art. 22.4 CP) apenas un año después. No obstante, al menos formalmente, la protección de la mujer en la adscripción de roles sociales pre-configurados no llegaría hasta la LO 1/2015. Véase PRATS CANUT, J.M., «Comentario al art. 22.4 CP: cometer el delito por racismo o xenofobia», en QuiNTERo Olivares, G. (dir.), Comentarios al Código penal. Tomo I. Parte general (artículos 1 a 137) ( $5^{a}$ ed.), Thomson Reuters Aranzadi, Cizur Menor, 2008, p. 324. En detalle, sobre este pulso legislativo mantenido hasta afincar el género donde actualmente radica en forma de agravante genérica, remitimos aquí a: OREJón SÁNCHEZ de las HerAS, N., La circunstancia agravante genérica de discriminación por razones de género, Iustel, Madrid, 2019, pp. 2760; Acale Sánchez, M., Violencia sexual de género contra las mujeres adultas. Especial referencia a los delitos de agresión y abuso sexuales, Reus, Madrid, 2019, pp. 127-130; ZAPATER FERRER, J.J., La circunstancia de desprecio de sexo en la jurisprudencia del Tribunal Supremo, Universidad de Valencia, Valencia, 1980, pp. 7-27. 
alude a que este último instrumento internacional exigía el establecimiento de tal agravante. Estas afirmaciones, sin paliativos, se reproducen ad litteram en posteriores ocasiones (STS 223/2019, de 29 de abril [FJ 3]; STS 351/2019, de 9 de julio [FJ 3] y STS 452/2019, de 8 de octubre [FJ 3]; STS 257/2020, de 28 de mayo [FJ 6]). Si esto es lo que fija el Tribunal Supremo, algunos órganos jurisdiccionales inferiores también se han venido haciendo eco de esta misma idea (SAP de Las Palmas de Gran Canaria 250/2019, de 12 de julio [FJ 6]; SAP de Madrid 628/2019, de 30 de octubre [FJ 5]; SAP de Granada 504/2019, de 16 de diciembre [FJ 5]; SAP de Las Palmas 45/2020, de 13 de febrero [FJ 5]; SAP de Sta. Cruz de Tenerife 42/2020, de 14 de febrero [FJ 5]; SAP de Madrid 151/2020, de 2 de marzo [FJ 3]). En distintos términos, y no de forma tan explícita, una lectura entre líneas de la importante SAP de Sta. Cruz de Tenerife 64/2017, de 23 de febrero (FJ 3) podría llegar a sugerir la idea de que la introducción de la agravante, precisamente en forma de agravante, obedece a las previsiones del Convenio de Estambul ${ }^{40}$.

Lo que sí que hace el Convenio de Estambul es ofrecer la definición más completa sobre violencia basada en el género (gender-based violence) que se conoce ${ }^{41}$. Si por «violencia contra las mujeres por razones de género» se entiende "toda violencia contra una mujer porque es una mujer o que afecte a las mujeres de manera desproporcionada» [piénsese, como paradigma de la desproporción a la que se alude, en los

40 El extracto en cuestión tiene el tenor literal que sigue: «Al respecto de esta agravación, debe incidirse en que su introducción en el vigente Código penal, como así se explica en el preámbulo de la Ley orgánica 1/2015, es consecuencia de las previsiones del Convenio del Consejo de Europa sobre prevención y lucha contra la violencia contra la mujer y la violencia doméstica, hecho en Estambul el 11 de mayo de 2011 y ratificado por España, mediante Instrumento de 18 de marzo de 2014, BOE 6 de junio 2014» (FJ 3). Siendo posteriormente confirmada (STSJ de Canarias 7/2017, de 26 de junio), lo cierto es que esta sentencia ha constituido un punto de retorno recurrente para otras venideras. De hecho, ya sea reproduciendo en su integridad el extracto anterior, mencionando la sentencia, o aludiendo a este particular en términos muy similares, véase el siguiente listado de sentencias firmes o posteriormente confirmadas: SAP de Cuenca 26/2017, de 7 de noviembre (FJ 4); SAP de Madrid 743/2017, de 1 de diciembre (FJ 7); SAP de Madrid 74/2018, de 13 de febrero (FJ 7); SAP de Madrid 160/2018, de 9 de marzo (FJ 5); SAP de Asturias 69/2018, de 9 de marzo (FJ 4); SAP de Bizkaia 34/2018, de 26 de abril (FJ 4); SAP de Madrid 299/2019, de 3 de mayo de 2018 (FJ 6); SAP de Burgos 179/2018, de 11 de mayo (FJ 7); SAP de Madrid 357/2018, de 24 de mayo (FJ 5); SAP de Madrid 514/2018, de 16 de julio (FJ 11); SAP de Madrid 172/2019, de 12 de marzo (FJ 9); SAP de Madrid 575/2019, de 26 de septiembre (FJ 9).

41 Una definición que, cabe notar, no resulta novedosa por más completa que sea. El tratamiento jurídico internacional que precede al Convenio de Estambul, a través de numerosos instrumentos a su alcance (Convenios, Declaraciones o Recomendaciones), da buena muestra de ello. Véase, junto con la relación bibliográfica a la que se remite la autora, Asua BATARrita, A., «La razón de género en el marco de la agravante «de odio» del art. 22.4 CP. Por una interpretación restrictiva frente al deslizamiento punitivo», en PÉREZ Manzano, M./Iglesias Río, M.A./De Andrés Domínguez, A.C./Martín Lorenzo, M./Valle Mariscal De Gante, M. (coords.), Estudios en homenaje a la profesora Susana Huerta Tocildo, Universidad Complutense de Madrid (UCM), Madrid, 2020, p. 368. 
delitos contra la libertad sexual] (art. 3.d) del Convenio), la «violencia contra las mujeres» que recoge la anterior definición se equipara a una violación de los derechos humanos ${ }^{42} \mathrm{y}$ a una forma de discriminación contra las mujeres, siendo así que abarca «todos los actos de violencia basados en el género que implican o pueden implicar para las mujeres daños o sufrimientos de naturaleza física, sexual, psicológica o económica, incluidas las amenazas de realizar dichos actos, la coacción o la privación arbitraria de libertad, en la vida pública o privada» (art. 3.a) del Convenio). El término mujer tampoco entiende de edad, por lo que niñas, adolescentes o mujeres adultas quedan encuadradas por igual en las definiciones anteriores (art. 3.f) del Convenio). Además, la violencia contra las mujeres se enmarca dentro de los contornos de un desequilibrio histórico entre hombre-mujer, siendo su naturaleza estructural la que dota de firmeza a esta situación de dominación latente y, en cierta medida irresuelta, en tanto que las razones de género constituyen la principal fuerza catalizadora.

Este entendimiento amplio del género conforme al Convenio vendría a ser, como también refleja la Exposición de Motivos de la LO $1 / 2015$, el verdadero motor de la introducción de las «razones de género» en forma de agravante genérica. Esta nueva categoría pasa a ejercer una función de refuerzo de la protección que ya dispensaba la agravante del art. 22.4 CP, puesto que el legislador entiende que "puede constituir un fundamento de acciones discriminatorias diferente del que abarca la referencia al sexo» (EM XXII, LO 1/2015). Ello en cualquier caso, y sin perjuicio de que puedan existir posicionamientos críticos que lo cuestionen ${ }^{43}$, es muy diferente a tratar de sugerir un

42 En cambio, sobre las dificultades y derivas justificativas en uno u otro sentido a la hora de considerar los delitos de odio como violaciones de derechos humanos, véase: Perry, B./Olsson, P., «Hate crime as a human rights violation», en PerRY, B./IgANSKI, P. (eds.), Hate crime (Vol. 2). The consequences of hate crime, Praeger (ABC-CLIO), Westport/ London, 2009, pp. 175-191; BRUdHolm, T., «Hate crimes and human rights violations», Journal of Applied Philosophy, Vol. 32 (1), 2015, pp. 82-97; BRUDHOLM, T., «Conceptualizing hatred globally: is hate crime a human rights violation?», en SCHWEPPE, J./WALTERS, M.A. (eds.), The globalization of hate. Internationalizing hate crime?, Oxford University Press, Oxford/Nueva York, 2016, pp. 31-48; GoRDON, I., «El delito de odio como violación de los derechos humanos. Notas destacadas sobre un reciente y desconocido desencuentro académico", en Landa Gorostiza, J.M. (dir.)/Garro CARRERA, E. (coord.), Retos emergentes de los derechos humanos: ¿garantías en peligro?, Tirant lo Blanch, Valencia, 2019, pp. 413-433.

43 Especialmente crítica en este sentido es, tanto con el Convenio de Estambul como con el legislador español, MAQueda ABREu, quien cuestiona abiertamente el sentido implantar un juego dual entre sexo (factor biológico)-género (factor cultural) que no sería tal, por cuanto el primero adquiere significado dentro de la agravante sólo en la medida en que viene "adulterado" por el segundo. Ser mujer involucra ambas realidades de forma indisoluble. Véase: MAQueda ABREU, M.L., "¿Necesitan un móvil discriminatorio las agravantes de sexo/género del art. 22.4 CP?», en Silva Sánchez, J.M./CaStiñeIRa Palou, M.T./Corcoy Bidasolo, M./Queralt Jiménez, J.J. (coords.), Estudios de Derecho penal: homenaje al profesor Santiago Mir Puig, B de F, Buenos Aires, 2017, pp. 707-708; MAQuedA Abreu, M.L., «El hábito de legislar...op. cit., pp. 7-11. 
compromiso estatal jurídicamente vinculante de incorporar necesariamente las "razones de género ${ }^{44}$ en la parte general del Código penal y, concretamente, en la circunstancia de agravación de delitos comunes por motivos discriminatorios (o, de crear ex professo una tal agravante). Más parece como si el Convenio hubiera ido al ralentí en esta materia, dejando a los Estados engranar una u otra velocidad al gusto. De hecho, lo más cerca que está el Convenio de proponer una figura penal en forma de agravante es cuando se refiere a que, en aplicación de las disposiciones del Convenio, los Estados no incurrirán en discriminación alguna si lo que adoptan son «medidas específicas necesarias para prevenir y proteger a las mujeres contra la violencia por razones de género» (art. 4.4). Para unos se tratará de un salto al vacío inaceptable. Para otros, en cambio, se tratará de una cláusula que despliega in abstracto cualquier camino que los Estados decidan a su buen criterio transitar, como perfectamente lo pueda ser el reflejo del género en forma de agravante del caso español. Por lo demás, el art. 46 del Convenio establece la necesidad de adoptar medidas legislativas en forma de agravante para las circunstancias que el propio artículo detalla y que lógicamente no estén ya de por sí recogidas en algún tipo o subtipo penal del derecho interno. Entre tales circunstancias, destaca la de que «el delito se haya cometido contra un cónyuge o pareja de hecho actual o antiguo, de conformidad con el derecho interno, por un miembro de la familia, una persona que conviva con la víctima o una persona que abuse de su autoridad» (art. 46.a) del Convenio). Al margen de que no se especifique el sexo de la víctima o que se circunscriba a un ámbito relacional muy concreto, los patrones de redacción no se ajustan, por razones obvias, a una genuina agravante por motivos discriminatorios de género. Pero es que incluso en caso de hacerlo, el legislador español mantendría intacta la prerrogativa de legislar conforme a subtipos agravados de género o nuevos tipos autónomamente considerados.

En definitiva, es la categoría género en sí misma - dentro o fuera de la agravante - lo que mueve al legislador a modificar la legislación penal existente. Por lo que justo es decir que el legislador ha optado por esta vía de refuerzo de los móviles discriminatorios dentro de la agravante del art. 22.4 CP como podría haber optado por otras técnicas de tipificación penal en materia de delitos de odio que dieran cabida a las «razones de género» (p.ej.: incluir otros tipos o subtipos penales con marca de género). La ambivalencia con la que se ha movido el legislador viene bien representada por la incardinación del género también dentro

44 El género como realidad que, eso sí, es un elemento normativo jurídico en la formulación dada por el art. 22.4 CP. En concreto, según la EM de la LO 1/2015, parece evidente que debe acudirse al Convenio de Estambul para explicar su sentido legal. Sentido que, recordemos, se amplía ahora considerablemente y supera el del mero ámbito privado, el cual se mantiene todavía —e incomprensiblemente-inalterado en el art. 1 de la LO 1/2004. Acale SÁnchez, M., Violencia sexual...op. cit., pp. 356-358. 
del delito de discurso de odio punible (art. $510 \mathrm{CP}$ ) o de los delitos de denegación discriminatoria de una prestación de carácter público (art. 511 CP) y de una prestación en el ámbito profesional o empresarial (art. $512 \mathrm{CP}$ ), pero no así en los delitos de discriminación en el ámbito laboral (art. $314 \mathrm{CP}$ ) y de asociación ilícita que promueva o incite a la discriminación, el odio o la violencia (art. 515.4 CP). Estos delitos están, como poco y según lo anteriormente expuesto, en la órbita de los delitos de odio (o delitos de odio lato sensu) y, por ende, dispersos en nuestra legislación penal. En definitiva, en términos generales, se podría decir que la política-criminal de género se consolida de forma diferenciada con tipos específicos de género y, a su vez, se refuerzan los preceptos generalistas antidiscriminatorios (arts. 22.4 y 510-512 CP). En las líneas que siguen se irán vislumbrando las fisuras de sistematización estructural que de ello derivan, realizando dicho acercamiento desde las «secuelas» que ha dejado el voluntarioso ejercicio de la labor judicial en nuestro país.

Finalmente, como apunta PentTinen, lo relevante de la definición de violencia contra la mujer que facilita el Convenio de Estambul es que arrastra otro aspecto tras de sí: la violencia psicológica y las amenazas de actos violentos (es decir, las señales de violencia próxima o warning signs of violence to come $)^{45}$, con diferencia las actitudes o comportamientos más silenciados, se equiparan plenamente a los actos de violencia material (actual violence) ${ }^{46}$. De esta forma, el Convenio antepone

45 A finales de la década de los noventa se impulsa en España la depuración de ciertas medidas legislativas en este sentido. La Circular 1/1998, de 24 de octubre, de la Fiscalía General del Estado, anunciaba ya la inminente corrección del delito de violencia familiar habitual del art. 153, como estandarte de la violencia en el ámbito familiar tras la entrada en vigor del vigente Código penal. Lo hacía de la siguiente forma: «Uno de los defectos señalados reiteradamente por la doctrina (...) es el de que incluye exclusivamente conductas de «violencia física», sin mención alguna de la psíquica. Defecto éste que pretende corregir el Anteproyecto, antes citado, de septiembre de 1998». Así, este cambio legislativo se consuma finalmente mediante LO 14/1999, de 9 de junio, de modificación del Código penal de 1995, siendo una «modificación que supone, entre otras innovaciones, (...) la tipificación como delito específico de la violencia psíquica ejercida con carácter habitual sobre las personas próximas» (EM II). Véase Fiscalía General del Estado, Circular 1/1998, de 24 de octubre, sobre la intervención del Ministerio Fiscal en la persecución de los malos tratos en el ámbito doméstico y familiar, FGE, Madrid, 1998, https://www.fiscal.es/ memorias/estudio2016/CIR/CIR_01_1998.html (último acceso: 13/09/2020).

46 Este proceso evolutivo es idéntico a los estudios de victimización que cambiaron la percepción que hasta la fecha se tenía sobre los delitos de odio en los Estados Unidos. De hecho, fue durante toda la década de los noventa cuando las investigaciones sobre los efectos de los delitos de odio corroboraron que, al margen de la brutalidad del daño físico experimentado por la víctima, se daban otros tipos de daños que no implicaban necesariamente una intromisión física (p.ej.: delito de acoso o stalking). Para un breve pero revelador recorrido por los estudios y contribuciones académicas que fueron pioneros en confirmar no sólo el impacto, sino la carga emocional y psicológica del mismo en las víctimas de delitos de odio, véase Iganski, P./SweIrY, A., «Hate crime», en Treviño, A.J. 
claramente su capacidad preventiva respecto a la reactiva ${ }^{47}$. Incluso así, este instrumento relativiza la que es su mayor baza, al disponer que los Estados pueden reservarse el derecho a prever sanciones no penales para conductas relacionadas con la violencia psicológica y el acoso (art. 78.3 del Convenio) ${ }^{48}$.

Por lo demás, como se verá, de entre todos los delitos a los que se ha añadido la agravante por razón de género, durante el primer trienio aplicativo de la agravante sólo una de un total de 40 infracciones penales $(2,50 \%)$ se corresponde con un delito de maltrato habitual (art. 173.2 y $3 \mathrm{CP})^{49}$ y $5(12,50 \%)$ con un delito de amenazas (art. $\left.169 \mathrm{CP}\right)^{50}$. Respecto al siguiente periodo que será objeto de examen, relativo al tercer y cuarto año desde la incorporación de las razones de género dentro de la agravante, sólo una de un total de 63 infracciones penales $(1,59 \%)$ se corresponde con un delito de maltrato ocasional (art. 153.1 CP $)^{51}$ y $7(11,11 \%)$ con un delito de amenazas (art. 169 CP) ${ }^{52}$. Por tanto, salvando los tipos vinculados a la violencia psicológica con marca de género (arts. 148.4, 153.1 y 173.2, 3 y 4 CP), el delito de amenazas agra-

(ed.), The Cambridge handbook of social problems (Vol. II), Cambridge University Press, Cambridge/New York, 2018, pp. 404-405.

47 Penttinen, E., «Gender agency and violence», en Gentry, C.E./ShePherd, L.J./SjoBERG, L. (eds.), The Routledge handbook of gender and security, Routledge, Londres/Nueva York, 2019, p. 254. A mayor abundamiento sobre cómo un modelo de corte «victimocéntrico» en el ámbito internacional se contrapone al modelo "criminocéntrico» o de nuda incriminación español, véase Villacampa Estiarte, C., Política criminal española en materia de violencia de género. Valoración crítica, Tirant lo Blanch, Valencia, 2018, pp. 111-116.

48 Acertadamente, Boldova Pasamar se pregunta cómo es posible que el Convenio de Estambul prevea la incorporación de una agravante común o genérica cuando, el propio Convenio, estima que algunas conductas $-\mathrm{y}$, añadimos, justamente las que mayor interés puedan suscitar dado que están perfectamente alineadas con su apuesta por lo preventivo- puedan quedar desligadas de todo trasfondo delictivo. De forma ampliada, incidiendo sobre la idea de una obligación inexistente que permita sostener el relato de la asociación del género con una agravante genérica de acuerdo con lo previsto por el Convenio de Estambul, véase Boldova PASAMAR, M.A., "El actual entendimiento de los delitos de violencia de género y sus perspectivas de expansión», InDret: Revista para el Análisis del Derecho, Núm. 3, 2020, pp. 191-193.

49 Se trata, en verdad, de un error en el mantenimiento de la agravación, ya que en primera instancia se condena por un delito del art. 173.1 y $3 \mathrm{CP}$ y el error material lo subsanaría la Audiencia Provincial sin aparentemente reparar en el ne bis in idem que implicaba la agravación por razones discriminatorias de género (SAP de Sevilla 163/2017, de 31 de marzo).

50 Véanse: SAP de Valladolid 240/2016, de 25 de julio; SAP de Valladolid 69/2017, de 21 de febrero; SAP de Cádiz 16/2018, de 19 de enero; SAP de Madrid 74/2018, de 13 de febrero (confirmada después por Auto de TS 961/2018, de 12 de julio); STSJ de Asturias 4/2018, de 2 de marzo.

51 Como puede observarse, esta sentencia de conformidad (SAP de Asturias 120/2019, de 22 de marzo) mantiene un sentido del fallo curioso y anecdótico.

52 Véanse: SAP de Asturias 120/2019, de 22 de marzo; STSJ de Madrid 195/2019, de 2 de octubre; SAP de Murcia 327/2019, de 16 de octubre; SAP de Palencia 27/2019, de 22 de noviembre; STS 663/2019, de 14 de enero de 2020; SAP de Madrid 41/2020, de 20 de enero; SAP de Cuenca 48/2020, de 8 de mayo. 
vadas por razones de género se ha mantenido, a cinco años vista de incorporar las razones de género en la agravante genérica, como el único exponente de violencia psicológica realmente sujeto a una agravación de género extraña al tipo $(12-11,65 \%)$. Y así, si el Convenio anteponía claramente su capacidad preventiva respecto a la reactiva, es precisamente esta última la que, simplemente por cómo queda configurado el mapa legal español, ha sido objeto de abuso (o de una aplicabilidad descompensada) vía art. 22.4 CP.

Por ello, y recordando una vez más que implementar dicha técnica de agravación no era un mecanismo obligatorio para cumplir con los compromisos de orden legal asumidos, el hecho de incorporar las razones de género al art. 22.4 CP provoca que, cuando menos en lo que respecta a esa novedad, los cambios realizados por LO 1/2015 no entonen bien con el espíritu del Convenio de Estambul. En buena medida, ello es así por la coyuntura que surge de la reforma legislativa en cuestiones de género, debiendo haberse debatido otras opciones de canalización legal. De haberse hecho así, se hubiera dotado a las razones de género de una mayor sintonía con un Convenio del que, se dice, traen causa.

\subsection{Búsqueda de equilibrio en un escenario legal tan nuevo como desconocido}

La reforma operada por LO 1/2015 dispuso una hoja de ruta incierta respecto a la circunstancia agravante del art. $22.4 \mathrm{CP}$. La respuesta penológica implementada ex novo parece adquirir connotaciones jurídicas difícilmente conciliables con la sistematización interna de nuestra legislación penal.

En términos de razonabilidad en torno a la intervención penal, se constata el ánimo expansivo y bienintencionado del legislador que aspira a cubrir casos en que cualquier mujer sea seleccionada por el mero hecho de serlo. Salvando debates como el del posible parche que venía representando la circunstancia mixta de parentesco (art. $23 \mathrm{CP}$ ), o incluso el alcance que podría brindar la categoría «sexo» en la agravante del art. 22.4 CP, la violencia de género debía ensanchar sus posibilidades de sanción penal a otras constelaciones de casos. Esto es, debía abarcar un abanico más amplio de supuestos que permanecían en un ángulo muerto en términos de mayor reproche penal (p.ej.: las lesiones graves de los arts. 149 y $150 \mathrm{CP}$ ). En teoría, ello enlaza además con la lógica transversal - y sin distingos - que subyace a cualquier tipo de violencia motivada por odio (p.ej.: violencia activada por cuestiones raciales, religiosas o de orientación sexual). Se trataría de un mecanismo corrector que posibilita un castigo dirigido a cualesquiera delitos en los que, por afectación directa o indirecta a la mujer, el género no fuera ya un elemento constitutivo del tipo (p.ej.: homicidio o asesinato). Dicho de otra 
forma, se difumina la frontera entre categorías de víctimas ${ }^{53}$, ya que dependiendo de las circunstancias del caso (p.ej.: relación víctima-agresor o delito cometido) se manifestaban posibles agravios comparativos a la hora de aplicar un mayor desvalor penal. Lo cierto es que el legislador rompe así con un asincronismo objetivo y ofrece una protección integral de la víctima-mujer. Todo ello, huelga decir, no debería prejuzgar el debate de fondo sobre la procedencia o no de dicha agravación.

Sin embargo, todo lo anterior no impide cuestionarnos la aplicación absolutamente sistemática que debería adoptar la agravante, así como sus consecuencias más directas y evidentes. Esto es, en teoría, el hecho de que la agravante se aplique ahora a todos los delitos en que la marca de género no estuviera incorporada en origen ${ }^{54}$, haría presagiar que ciertos delitos graves como son los de sangre (homicidio o asesinato) habrían de recibir una sanción todavía mayor ${ }^{55}$; o que incluso la aplicación de los tipos equivalentes neutros ( la aplicación del art. 22.4 CP favorecerían un tratamiento más gravoso que el que hoy por hoy recogen los delitos con marca de género ${ }^{56}$. La nueva agravante se vendría a consolidar como un asidero en una ubicación sistemática clave, por el alcance omnicomprensivo que despliega a la práctica totalidad de tipos de la parte especial del Código penal. Así pues, la práctica judicial tenía una empresa importante por delante para canalizar lo que para algunos era un verdadero desatino legislativo ${ }^{57} \mathrm{y}$

53 El Convenio de Estambul estipulaba ya que los hechos penalmente relevantes cometidos dentro del marco de una relación sentimental, presente o pasada, no colmaban la protección —necesariamente más transversal- que debía dispensarse a la mujer para este tipo de violencia. En concreto, el Convenio prevee lo siguiente: «Los delitos previstos en el presente Convenio se sancionarán con independencia de la relación existente entre la víctima y el autor del delito» (art. 43 del Convenio).

${ }_{54} \mathrm{Si}$ bien algunos delitos han encontrado un grado de acogida más o menos notable bajo la estela de esta etiqueta de género (arts. 148.4, 153.1, 171.4 y 172.2 CP), la perspectiva de género puede estar más cuestionada en otros (arts. 172 ter, 173.2, 173.4, 197.7 y 468 $\mathrm{CP})$ por la indiferenciada e imprecisa alusión al sujeto pasivo, estimulando así la contraposición entre violencia de género y violencia doméstica.

55 Según se desprenderá de los subapartados «4.1.1. Sentencias condenatorias o confirmatorias de condena dentro del primer trienio aplicativo de referencia (2015-2018)" y «4.1.2. Actualización de datos (2018-2020)» infra, el delito de asesinato se mantiene como aquél al que con más frecuencia se adiciona el desvalor propio de la agravante en sentencias condenatorias o confirmatorias de condena. Lo que es más, según el grado de ejecución alcanzado, el delito de asesinato consumado sería el predominante.

56 En esta línea, véase una referencia en SANz Mulas, N., Violencia de género y pacto de estado. La huida hacia adelante de una norma agotada (LO 1/2004), Tirant lo Blanch, Valencia, 2019, p. 96.

57 Según Villacampa EstiarTe, la LO 1/2004 ya adoptaba un cariz especialmente punitivista a la luz del desequilibrio entre la transversalidad de las medidas jurídicas pretendidas y la inusitada frecuencia en que la normativa había apostado por forzar la maquinaria penal como canal preferente de actuación (Derecho penal como prima ratio). De hecho, esta autora fue, junto con propuestas de otras pioneras que ella misma menciona y respalda, partidaria de la implementación de una circunstancia agravante por razones de género genérica como la que actualmente se encuentra en el art. 22.4 CP. En realidad, el 
afianzar así un espacio jurídico propio destinado a la nueva agravante, de tal forma que no se diera alas al sobre-punitivismo de género como verdadera - pero errónea- forma de empoderamiento de la mujer a través del Derecho penal. Sobre esta forma de legislar en materia de violencia de género, es decir, con gran apego al Derecho penal más paternalista e imponderable respecto a sus consecuencias, numerosas voces académicas han denunciado, en tono crítico, el derrotero especialmente punitivista de la política-criminal española ${ }^{58}$. Un rumbo que damnifica y estigmatiza a la mujer, puesto que la presenta como lábil y merecedora de una especial atención y deferencia, al tiempo que la empuja con fuerza a acudir al sistema penal como canal correcto de actuación ${ }^{59}$. Además, este canal que se entiende equívocamente como preferente magnifica

problema radica en que desde el año 2015 se han superpuesto ambos estándares, tanto el acogido en 2004 como el pretendido por parte de la doctrina pero finalmente desechado en aquel momento en favor de las figuras penales específicas con la marca de género inherente. Según esta autora, el primer estándar perdería ahora todo su sentido. En esta misma línea, ACALE SÁNCHEZ cree que la actual agravante genérica por razones de género cuestiona frontalmente y hace tambalear el modelo de intervención penal en materia de violencia de género. En opinión de MAQUEDA ABREU, todas estas autoras quizás no repararon en su momento en que la categoría del «sexo» dentro de la agravante del art. 22.4 $\mathrm{CP}$ ya podía - si bien incomprensiblemente no lo hacía- suplir la tan ansiada agravante genérica. Véase: VilLACAMPa EstiaRTe, C., «El maltrato singular cualificado por razón de género. Debate acerca de su constitucionalidad”, RECPC, Núm. 9, 2007, p. 19; VILLACAMPA Estiarte, C., "Pacto de estado en materia de violencia de género: ¿más de lo mismo?», RECPC, Núm. 20, 2018, pp. 19-20; Villacampa Estiarte, C., Política criminal española... op. cit., pp. 51-53; Acale SÁnchez, M., Violencia sexual...op. cit., pp. 363-364; MaQueda ABREU, M.L., «El hábito de legislar...op. cit., p. 13. Véase también GORJÓN BARRANCO, M.C., «Hacia un concepto amplio de violencia de género más allá de la mujer-pareja», en RoIG TORRES, M., Últimas reformas legales en los delitos de violencia de género. Una perspectiva comparada, Tirant lo Blanch, Valencia, 2018, pp. 76-79.

58 Lejos de ser una seña distintiva de nuestra política-criminal, BRown especulaba ya a mediados de los noventa sobre esta cuestión. En concreto, esta teórica feminista plantea la siguiente reflexión acerca de la tendencia a relegar un problema político-cultural a la culpa individual y al punitivismo ciego como forma inopinada de protección: «Cuando la «herida» social es transferida a la ley para su resolución, el terreno político cede ante el terreno moral y judicial. Una herida social como la transmitida por medio del discurso despectivo [mutatis mutandis, la que se proyecta en los delitos «de actos» de odio es equiparable] se convierte en lo que es «inaceptable» y "culpable individualmente», en vez de aparecer como el síntoma de un profundo dolor político en una cultura; así, el agravio se representa como intencionado e individual, la política queda reducida al castigo y la justicia se iguala a ese castigo, por una parte, y a la protección de los tribunales, por la otra». BRown, W., Estados del agravio. Poder y libertad en la modernidad tardía, Lengua de Trapo, Madrid, 2019, p. 89. Véase la obra original: Brown, W., States of injury. Power and freedom in late modernity, Princeton University Press, Princeton, 1995, pp. 27-28.

59 Entre otras, véanse las siguientes aportaciones recientes que examinan y profundizan para finalmente criticar el sesgo exasperantemente punitivo (fuera de toda proporción o conveniencia) emprendido hace tiempo, aunque con signos evidentes de plena vigencia: LARRAURI PiJOAN, E., Criminología crítica y violencia de género ( $2^{a}$ ed.), Trotta, Madrid, 2018, pp. 55-82; LaURENZo Copello, P., «¿Hacen falta figuras género específicas para proteger mejor a las mujeres?», Estudios penales y criminológicos, Núm. 35, 2015, pp. 798-811; Villacampa Estiarte, C., Política criminal española...op. cit., pp. 105-116. 
las respuestas penales ante conductas no tan graves en abstracto, lo que puede alentar a construir un imaginario social donde se revierta instintivamente la imagen de víctima-agresor ${ }^{60} \mathrm{y}$, por tanto, donde se ahonde en la revictimización de la mujer.

\subsection{Derecho penal comparado: particularidades e incidencia de la agravante en algunos sistemas de justicia penal del common law}

Al comienzo de este estudio ya se ha apuntado la especial influencia que la OSCE ha proyectado en materia de delitos de odio, así como los dos grandes modelos legislativos que sirven de fundamento para su reflejo penal («discriminatory selection model» $\mathrm{y}$ "[racial] animus model»). Pues bien, cabe avanzar ya que ha sido el modelo de selección discriminatoria por el que se ha decantado esta organización. Según explica GOODALL, esto es así porque el daño que se puede causar a la víctima - y a su grupo de pertenencia- en los instantes en los que se sopesa la selección de la víctima sería el mismo que cuando el autor actúa movido por actitudes racistas y causa tal daño. Pero es que incluso si fuera diferente, siempre sería más fácil recabar pruebas sobre la selección consciente que sobre el móvil de autor ${ }^{61}$. En breve retomaremos

60 Sobre estudios acerca de la victimización del hombre, además, existen precedentes que datan de comienzos del s. Xx. Al hilo del examen de trabajos freudianos sobre agresión grupal y psicología de las masas, se ha argumentado que el individuo varón también sufre "hacia adentro» su pertenencia al grupo dominante. Según hilvana en su examen de la obra de FREUD el intelectual canadiense IGNATIEFF, el individuo se debe despojar de todo cuanto lo separe del grupo, luchando así contra su propia individualidad para adecuarse o, en palabras del autor, "encajarse la máscara del odio». De esta forma, lo que hará será pagar el precio psíquico de una cruenta lucha interna. Esa adecuación grupal puede traer causa de diferencias humanas menores como puedan ser el género o la raza, siendo los privilegios que a éstas acompañan lo que realmente marca la diferencia y posibilita una dinámica opresiva de dimensiones estructurales. En suma: «El poder es el vector que agranda lo pequeño». Y ese poder plenamente representado en el hombre causaría también, según lo ya referido, efectos inadvertidos incluso para el propio individuo varón. Ello es, si se quiere y por seguir con la terminología empleada, un "sufrimiento» contingente y privilegiado, ya que estaría sujeto a la comodidad que ofrece adecuarse al sistema contra el que dice contraponerse la individualidad de cada varón en origen. En detalle, véase IgNATIEFF, M., El honor del guerrero. Guerra étnica y conciencia moderna, Taurus, Madrid, 1999, pp. 51-56.

61 Goodall, K., "Conceptualising 'racism' in criminal law», Legal Studies, Vol. 33 (2), 2013, pp. 227-230. Ya en 1994, ANGELARI se refería a las dificultades con las que se encontraban los operadores jurídicos que, teniendo voluntad de aplicar la agravación por motivos discriminatorios y proteger a la mujer, les preocupaba cómo probar la motivación de autor. Hasta tal punto les preocupaba este extremo que ya existían estudios situándolo como el principal obstáculo para los fiscales a la hora de perseguir los prejuicios de género. Siendo así, ANGELARI lanza la pregunta al aire de por qué entonces la motivación de autor no estaba siendo un impedimento real —no sólo teórico- a la hora de probar la 
de nuevo esta idea. Para decantarse por uno u otro modelo, la OSCE también se apoya en el cuerpo de decisiones judiciales (case-law) construido durante años en Estados Unidos sobre la agravación de la pena por motivos prejuiciosos. Sobre este particular, GOODALL cree que en el case-law de Estados Unidos se contienen más bien, salvo contadas excepciones, decisiones ambivalentes ${ }^{62}$. No existe una postura definida sobre un modelo de referencia ${ }^{63}$, por lo que quienes crean ver lo contrario es porque en realidad están forzando la interpretación del lenguaje ambiguo que se emplea en los pronunciamientos judiciales sobre agravaciones de la pena.

Por lo demás, en el año 2002, McPhaIL alude a que la inclusión del género dentro de la legislación de los delitos de odio estaba siendo un gesto más simbólico de lo que a priori cabía pensar, ya que raramente se invocaba ${ }^{64}$. Ya en 2018, haciendo acopio de numerosos estudios posteriores $^{65}$, STEARNS resalta las vacilaciones y titubeos de fiscales y jueces a la hora de apostar por derivar o no el caso a la agravación por razones de género. Entre las diferentes conclusiones que se desprenden de los estudios realizados, jueces y fiscales se mostrarían reacios a tal posibilidad porque los delitos violentos (p.ej.: agresión sexual, asesinato, etc.) contra las mujeres son concebidos como meros indicadores de rasgos de la personalidad relacionados con el poder y la búsqueda de control ${ }^{66}$. Es decir, se incide en la culpa individual del sujeto en un ámbito relacional privado ${ }^{67}$. Tratar de equiparar los prejuicios sexistas

delincuencia con connotaciones raciales. ANGELARI, M., "Hate crime statutes: a promising tool for fighting violence against women», The American University Journal of Gender, Social Policy \& the Law, Vol. 2 (63), 1994, pp. 98-99.

62 Con gran detalle, además de una selección de los pronunciamientos más destacados, véase Goodall, K., "Conceptualising...», op. cit., pp. 224-227.

${ }_{63}$ Sirva aquí con apuntar que una gran mayoría de legislaciones estadounidenses requieren probar que la víctima haya sido seleccionada «debido a», «a causa de» o "por razón de» (p.ej.: because of o by reason of) su pertenencia (o presunta pertenencia) a un grupo protegido.

${ }_{64}$ McPhaIL, B.A., "Gender-bias hate crimes. A review», Trauma, violence \& abuse: SAGE journals, Vol. 3, 2002, p. 130.

65 Por su relevancia, destacamos el siguiente estudio: McPhaIL, B.A./DiNitTo, D.M., «Prosecutorial perspectives on gender-bias hate crimes», Violence against women, Vol. 11 (9), 2005, pp. 1162-1185.

66 STEARns, E., «Hate and gender», en Valeri, R.M./Borgeson, K. (eds.), Hate crimes. Typology, motivations, and victims, Carolina Academic Press, Durham, 2018, p. 181.

67 Sin embargo, PERRY entiende que el denominado como "gendered hate» (es decir, delitos de odio cometidos por razones de género) debería ayudar a visibilizar toda la crudeza de los patrones sistemáticos de opresión a la mujer, sustentados por actos recurrentes que provienen indistintamente de cualesquiera actores sociales (p.ej.: novio, marido o un desconocido) que comparten el terreno común de una jerarquía de género que se retroalimenta con cada acto. Esta autora, pionera en muchos aspectos relacionados con el abordaje de las dimensiones socio-estructurales de los delitos de odio, asegura que más bien sería el hecho de que la categoría género no formara parte del articulado de los delitos de odio lo que acentuaría una visión de la violencia de género como fenómeno 
con otro tipo de prejuicios, como el racial, que rescata siglos de sufrimiento y conciencia moderna ampliamente compartida, sembraría confusión tanto al aplicador de la ley como al ciudadano medio americano que fuera miembro de un jurado. De esta forma, el escaso margen de maniobra que resta para dotar al género de algún mínimo sentido aplicativo lleva a los operadores jurídicos a estimar que sólo aquellos actos realizados por un completo desconocido ${ }^{68}$ podrían ser encauzadas por la vía agravada de género ${ }^{69}$. El resultado, en todo caso, es que los distintos eslabones que configuran el sistema de justicia penal vendrían optando por bordear la violencia cometida en el círculo íntimo de la víctima mujer ${ }^{70}$, en favor del castigo de ataques dirigidos contra un miembro cualquiera (aleatoriedad) y sustituible (intercambiabilidad) del grupo de pertenencia ${ }^{71}$.

Aún poniendo el foco también en personas que se hallan extramuros del círculo íntimo o social de la víctima, existen voces académicas interesantes que defienden el papel importante que jugaría el género como agravante en la práctica judicial. Situándonos ahora en Australia, esta sería la postura adoptada por MAHER/MCCULLOCH/MASON, quienes sostienen que los jueces y tribunales pueden valerse de las aggravated sentencing

delictivo perteneciente al ámbito privado. PERrY, B., In the name of hate. Understanding hate crimes, Routledge, Nueva York/Londres, 2001, p. 210.

68 Este lógica de aplicación de la agravante no estaría exenta de una explicación de corte más sociológico. A este fin, sirva con plantear aquí que la violencia sexual, no siendo la única, sí que es la más característica de entre las recreaciones machistas sobre el cuerpo de la mujer. Como es de sobra conocido, el componente sexual del acto forma parte intrínseca de la violencia de género. Pues bien, ya en 1979 la socióloga BARRY hablaba abiertamente de auténtico terrorismo sexual, en el sentido de que este tipo de violencia permea las vidas de las integrantes del colectivo mujer y perdura de forma intergeneracional entre víctimas directas y aquellas otras que lo son - y que irremediablemente, sea o no su voluntad, lo seguirán siendo- cuando menos en potencia. La violencia sexual queda entonces construida por actos de una desmesura e infiltración social incalculables, hasta el punto de pasar a ser un modus vivendi, el cual se digiere y debe cada miembro del colectivo resignarse a sobrellevar. En definitiva, la violencia sexual se compone de actos ilimitados en su potencial, alcance y profundidad social. El efecto in terrorem, tan asociado hoy con la victimización por odio, que se traduce en una sensación de vulnerabilidad y miedo expansivo a miembros de un colectivo, es perfectamente equiparable a todo lo anterior. BARRY, K., Esclavitud sexual de la mujer, LaSal. Edicions de les dones, Barcelona, 1987, pp. 55-56.

69 En detalle, véase STEARNS, E., «Hate...op. cit., pp. 180-182.

70 Se arguye también el mantra de la saturación que supondría para el sistema atender debidamente (p.ej.: carga de la prueba, recogida y organización estadística de datos, etc.) cualquier tipo de violencia contra la mujer como posible delito de odio. Y ello, tal vez, hasta el punto de relativizar o especular sobre la menor incidencia del fenómeno de victimización en personas seleccionadas por otros rasgos identitarios protegidos (p.ej.: raza, etnia, etc.).

71 Según GeRSTENFELD, ningún estado norteamericano de los que habrían acogido el género como categoría protegida dentro de la lógica de los delitos de odio adopta esta premisa, al menos de forma expresa, si bien sí que advierte de cuán probable es que este razonamiento se esté dando de facto en la toma de decisiones por parte de los fiscales. GERSTENFELD, P., Hate crimes. Causes, controls and controversies (4thed.), SAGE, Los Ángeles/ Londres, 2017, p. 62. 
provisions (agravaciones en la fase de determinación de la pena) ${ }^{72}$ para corregir el desvío en el que incurren los medios de comunicación al reforzar la división entre, por un lado, los crímenes mediáticos cometidos por desconocidos y, por otro lado, las formas más comunes de violencia contra la mujer sin tanta cobertura mediática. Esta realidad descompensada se produce porque los delitos cometidos por extraños atraen mucho más la atención mediática al estar la mujer perfectamente ensamblada dentro del canon de "víctima ideal» de delitos de odio cometidos por razones de género. En cambio, la víctima que conserva lazos afectivos con el victimario se distancia de este prototipo y recibe a menudo menos simpatía y, por consiguiente, menos reconocimiento. La agravación de la pena en manos del poder judicial puede coadyuvar a dar cuenta de todo cuanto une a esos dos universos ficticiamente separados. Es decir, mediante este mecanismo se puede denunciar que el delito concreto cometido fuera de la pareja representa un mero saliente de la práctica más invisible y común que tiene lugar dentro del núcleo familiar o afectivo de la víctima mujer. En palabras de estos autores, el castigo agravado de casos singulares, violentos y excepcionales (delitos cometidos por desconocidos) crea lazos comunes y arroja más luz sobre prácticas sociales imperceptibles (delitos cometidos dentro de la pareja). El efecto último es que se recrea la violencia de género como una práctica más general e inaceptable, en beneficio además de conceder al género una mínima utilidad aplicativa dentro de los delitos de odio ${ }^{73}$.

En el caso australiano, a diferencia de la ambivalencia estadounidense ya apuntada, las legislaciones sobre delitos de odio apuestan por un lenguaje inequívocamente motivacional ${ }^{74}$. Según MASON/DyER, una interpretación teleológica de la ley hace pensar que lo que se ha pretendido es imponer un estándar probatorio más alto $^{75}$. Las agravaciones en

72 La agravación de la pena («penalty enhancement») es posible que se dirima en una fase separada y propia de jurisdicciones de common law, denominada fase de determinación de la pena («sentencing stage»). De esta forma, siendo ya el agresor culpable de la comisión del delito correspondiente («offence stage»), el tribunal entrará a valorar la existencia del prejuicio que subyacía al acto en sí al momento final de dictar sentencia. En el derecho continental, como es conocido, no existe una división de fases.

73 A mayor abundamiento, véase el estudio completo en MAHER, J.M./McCulLoch, J./ MAsON, G., «Punishing gendered violence as hate crime: aggravated sentences as a means of recognising hate as motivation for violent crimes against women», Australian Feminist Law Journal, Vol. 41 (1), 2015, pp. 177-193.

${ }_{74}$ Por ejemplo, el art. 5(2)(daaa) de la Sentencing Act 1991 (Vic) se refiere a que el delito estuviera «motivado (total o parcialmente)" [motivated (wholly or partly)] por odio o prejuicios.

${ }_{75}$ En el caso del género, el estándar queda especialmente acentuado, pues ya de por sí a fiscales y jueces les cuesta identificar la agravación por razones discriminatorias de género cuando parece evidente que efectivamente así ha podido ser a juzgar por las pruebas obtenidas. La tasa de condena en delitos de odio es baja, pero todo apunta a que una interpretación centrada en el ánimo de autor impacta muy negativamente en la operatividad de la categoría de género. 
la fase de determinación de la pena en Australia justifican el aumento de la pena porque el daño infligido lo ha sido, de forma intencional o temeraria, por actos delictivos prejuiciosos. La mera selección de la víctima, no acompañada de prueba que atestigüe que el delito se ha cometido por razones prejuiciosas, no ha lugar a una pena agravada. Según entienden estos autores, aunque se materialicen actos basados en estereotipos (p.ej.: racistas, de género, etc.), eso ni confirma ni desmiente que la acción del autor venga - siquiera parcialmente- estimulada por una motivación prejuiciosa (p.ej.: decido robar algo a una mujer por razones prácticas, ya que es asumible que, en términos generales, opondrá menos resistencia que un hombre). En teoría, el modelo de selección discriminatoria podría llegar a captar este caso y elevar la pena de autor, no así el modelo motivacional. En realidad, lo que se modula es la culpabilidad de autor, siendo menos culpable quien actúe movido por razones diferentes a un motivo prejuicioso (y viceversa). Ahora bien, estos autores reconocen que el daño que conlleva un acto de mera selección puede ser igual o mayor al que supondría un acto con un componente motivacional detrás. Sin embargo, según indican, ese acto de mera selección nunca se habría llevado a cabo de forma intencional o temeraria ${ }^{76}$. En este último punto discrepo con la argumentación, puesto que el modelo de selección discriminatoria no constituye una formulación teórica estándar e inamovible, pudiendo llegar a exigirse incluso un elemento intencional en la acción selectiva del sujeto ${ }^{77}$. Además, creo que una perspectiva pro-víctima nunca debería ser completamente desatendida, como parece que sugiere el enfoque motivacional.

Prueba de que es preferible que el modelo de selección discriminatoria no sea completamente desatendido es, por ejemplo, la doble vía (subjetivo-objetiva) que nos plantea el sistema legal inglés ${ }^{78}$. En este caso,

76 En detalle, véase MASON, G./DYER, A., "'A negation of Australia's fundamental values': sentencing prejudice-motivated crime», Melbourne University Law Review, Vol. 36, 2013, pp. 896-897.

${ }_{77}$ En realidad, hay que tener en cuenta que tanto el «[racial] animus model» como el «discriminatory selection model» son lo suficientemente heterogéneos en sus formulaciones teóricas como para que no exista consenso académico acerca de su delimitación y alcance. Por ejemplo, en el caso del «discriminatory selection model», las posturas van desde la mera selección intencional de la víctima perteneciente a un colectivo, sin que sea preciso aprehender el significado implícito que conlleva la acción, hasta un mínimo conocimiento del carácter especial que tiñe la acción y/o sus consecuencias. $\mathrm{O}$, incluso, que se pueda demostrar la intención de ejecutar unos hechos contra una persona por ser quien es, o la de buscar un daño mayor precisamente por esto último. Goodall, K., «Conceptualising... op. cit., pp. 227-230.

78 Según la Crime and Disorder Act 1998 (en adelante, CDA), el delito será agravado si: a) al tiempo de cometer el delito, o inmediatamente antes o después de cometerlo, el autor manifiesta [to demonstrate] hostilidad [hostility] hacia la víctima del delito basada en su pertenencia (o presunta pertenencia) a un grupo racial o religioso [test objetivo]; o b) está motivado (total o parcialmente) por la hostilidad [motivated (wholly or partly) by hostility] hacia miembros de un grupo racial o religioso y basada en su pertenencia 
la legislación también se diseñó desde un primer momento en términos exclusivamente motivacionales. Sin embargo, el Gobierno no tuvo reparos en reconocer a tiempo que existirían dificultades probatorias, por lo que acabó introduciendo un test menos subjetivo y más realista. Además, aclaraba, ello permitía ofrecer un estándar más bajo y, previsiblemente, captar un mayor número de $\operatorname{casos}^{79}$. Se trata de una estrategia diametralmente opuesta a la seguida en Australia. Y es que, normalmente, la prueba que demuestra la motivación interna del agresor suele servir también para desenmascarar la relación de poder y efecto de dominación sobre la víctima y su grupo de pertenencia, pudiendo entonces plantearnos qué esperamos que nos aporte situar los lindes del debate irremediablemente en sede culpabilística ${ }^{80}$.

a dicho grupo [test subjetivo]. Este doble test se implementó para un grupo reducido de delitos pre-existentes, los cuales pasaban a constituir nuevos tipos penales en paralelo a aquellos otros que no contenían la agravación prejuiciosa (arts. 28-32 de la CDA). También se introdujeron disposiciones agravatorias en la fase de determinación de la pena. Estas disposiciones, entre otros aspectos que puedan ser de interés, mantuvieron intacta esa doble vía (objetivo-subjetiva) alternativa de incriminación (en su momento, art. 82 de la CDA; actualmente, arts. 145 y 146 de la Criminal Justice Act 2003). Si bien otras características han ido sumándose a las disposiciones agravatorias en la fase de determinación de la pena, todavía no se contiene el género como categoría protegida. A pesar de ello, los debates acerca de su inclusión mantienen su vigencia y actualidad. Sin ir más lejos, la Law Commission for England and Wales anunció en 2019 que los delitos de odio por razones de género (gender-based hate crimes) se analizarían como parte de un estudio más amplio sobre delitos de odio que dicha Comisión se había comprometido a realizar. Para un seguimiento del proyecto, véase https://www.lawcom.gov.uk/project/hate-crime/ (último acceso: 13/09/2020). De entre los estudios académicos centrados en esta misma problemática, véase: Walters, M.A./Tumath, J., «Gender 'hostility', rape, and the hate crime paradigm", The modern law review, Vol. 77 (4), 2014, pp. 563-596; BARKER, J./JURASZ, O., Online misogyny as a hate crime. A challenge for legal regulation?, Routledge, London/New York, 2019; DugGan, M., "Gender and hate crime protections», en AshFord, C./Maine, A. (eds.), Research handbook on gender, sexuality and the law, Edward Elgar Publishing, Cheltenham/Northampton, 2020, pp. 317-329.

79 En detalle, véase LENG, R./TAYLOR, R.D./WASIK, M., Blackstone's guide to the Crime and Disorder Act 1998, Blackstone Press, Londres, 1998, pp. 42-43.

80 En opinión personal del juez Lord Justice May en el caso RG, LT v DPP, resuelto en 2004 en Reino Unido, la motivación subyacente — esto es, el prejuicio racial- puede quedar determinada mediante la prueba de lo que ha dicho o ha hecho el propio agresor, si bien acudiendo a otra/s ocasión/es. El juez estima que, quizás incluso frecuentemente, el tipo de prueba requerida y que determina dicha motivación (vertiente subjetiva legalmente recogida para los delitos de odio en el sistema legal inglés) se satisface con la misma que determinaría la demostración de hostilidad racial exteriorizada en el acto (vertiente objetiva de los delitos de odio legalmente recogida para los delitos de odio en el sistema legal inglés). Este sería el caso de los comentarios o actitudes sexistas por parte del agresor varón. En esencia, como ya hemos mencionado recientemente, este juez también apunta a que la diferencia entre ambas vertientes radica en el momento temporal al que se refieran los hechos probados. No en vano, resulta que la ley del sistema legal ingles que recoge los castigos agravados por razones discriminatorias (Crime and Disorder Act 1998, arts. 2832) determina que éstos sólo proceden en la vertiente objetiva de los delitos de odio en la medida que se demuestre la hostilidad hacia la víctima durante el acto delictivo o inmediatamente antes o después de cometerse. Nada de esto se dice, en cambio, respecto a la 
Una reflexión interesante acerca del fundamento de la legitimidad penal en materia de delitos de odio es la que presentan DUFF/MARHALL. Para estos autores, lo importante es lo que se dice a la víctima o sobre la víctima con una acción. El sentido comunicativo cristalizado en los hechos nos sitúa en un plano alejado de meras inferencias de lo que parece que se estaría dando a entender con la acción. Es decir, la motivación de autor pierde fuerza en favor del significado que proyecta el acto en sí. De esta forma, por ejemplo, no importará por qué alguien se suma a una agresión racista (p.ej.: para buscar una aceptación de grupo entre simpatizantes violentos y con actitudes racistas), sino que lo haga. El significado es el mismo, pues conecta según estos autores con la emisión de un mensaje de exclusión de la identidad cívica o del sentido de pertenencia de una persona, en representación de un colectivo, a una sociedad. La responsabilidad delictiva no depende tanto del elemento intencional, sino del conocimiento de que la conducta tenga, o puede percibirse que tenga, ese significado. La conducta no debe venir motivada por lo que estos autores denominan como "odio cívico" (civic hatred), sino que debe comprobarse que con la ejecución de la conducta se demuestre esa actitud. Y lo que es más importante, la actitud debe manifestarse en el momento y con motivo de cometer ese delito en concreto ${ }^{81}$. Según DUFF, si la conducta es verbal el significado de la misma será más explícito, pero las actitudes de exclusión pueden igualmente materializarse con comportamientos no verbales. Será cuando estos actos prejuiciosos se concreten contra un grupo vulnerable y adquieran una dimensión colectiva que existirán razones de peso para justificar la intervención penal. Y ello es así porque es el contexto el que colorea la conducta y, por ende, el que acaba determinando el significado de la misma. La materialización de la conducta se torna «realmente amenazante» (genuinely threatening) para con tales miembros de la sociedad, y no para con otros. El riesgo de estar castigando aspectos más propios del fuero interno de la persona, frecuentemente vinculados al enfoque motivacional, se disipa con esta lectura, puesto que lo reprobable es el sentido que adquiere la conducta materializada (p.ej.: lo que hace o dice el autor) ${ }^{82}$.

vertiente subjetiva de los delitos de odio. Aun así, como se recoge en Jones v Bedford and Mid-Bedfordshire Magistrates' Court (2010), ambas facetas de los delitos de odio pueden satisfacerse simultáneamente atendiendo a unos mis hechos, incluso admitiendo que la objetiva se centra en el efecto producido sobre la víctima y la subjetiva lo haga poniendo el foco en la motivación que conduce a la acción. Véase: $R G$, $L T$ v DPP [2004] EWHC 183 (Admin), párrs. 13-14; Jones v Bedford and Mid-Bedfordshire Magistrates' Court [2010] EWHC 523, párr. 18.

${ }_{81}$ En detalle, véase DufF, R.A./Marshall, S.E., «Criminalizing hate?», en BrudHOLM, T./Johansen, B.S. (eds.), Hate, politics, law. Critical perspectives on combating hate, Oxford University Press, Oxford/New York, 2018, pp. 115-149.

82 DuFf, R.A., The realm of Criminal law, Oxford University Press, Oxford/Nueva York, 2018, pp. 200-201 y 307-308. 


\section{Estudio jurisprudencial}

\subsection{Algunos datos sobre la agravación de delitos comunes en España}

La muestra final obtenida refleja que, desde el 1 de julio de 2015, que marca la entrada en vigor del género como categoría protegida, y hasta el 1 de julio de 2018, que marca el final del periodo sujeto a examen, ascienden a treinta y cuatro las sentencias condenatorias o confirmatorias de condena que, habiendo ganado firmeza antes o después ${ }^{83}$, han agravado la pena por haberse cometido el delito correspondiente por razón de género.

Con todo, esta cifra en sí misma no arroja luz suficiente como para deducir cómo dotan de contenido los jueces y tribunales a la categoría "género». Lo que es más, podría parecer incluso una cifra intrascendente o modesta para una circunstancia modificativa de la responsabilidad penal que, a mediados de 2018, alcanzaba ya los tres años de recorrido aplicativo desde que la reforma penal de 2015 diera cabida al género dentro del art. 22.4 CP. Nada más lejos de la realidad. El género se ha convertido, de un tiempo a esta parte, en la categoría protegida más empleada por jueces y tribunales de nuestro país para sostener la agravación de la responsabilidad penal ${ }^{84}$. Según se desprende de una nueva búsqueda y seguimiento jurisprudencial, pero sin circunscribir tal búsqueda al género en específico, desde la entrada en vigor del actual Código penal (mayo de 1996) y hasta el 1 de julio de 2018 constan, salvo error u omisión, ciento treinta y seis sentencias condenatorias (o confirmatorias de condena) por aplicación del art. $22.4 \mathrm{CP}^{85}$. Es decir, treinta y cuatro del total de las resoluciones (25\%) están agravadas sólo por razón

83 Algunas de las treinta y cuatro sentencias condenatorias serían confirmadas por instancias superiores con posterioridad al 1 de julio de 2018. Más adelante se detallarán en específico cuáles son.

${ }_{84}$ Esta afirmación se sostiene si desgajamos la categoría raza o etnia en sub-realidades de victimización diferenciadas (p.ej.: negro, árabe, asiático, gitano, latino, etc.) y no como un todo indisoluble (p.ej.: raza, etnia, etc.). Incluso de no adoptarse este último criterio de aproximación, como se tendrá ocasión de comprobar, ello no merma el indudable impacto que ha tenido el género como categoría protegida, que es lo que verdaderamente interesa destacar en las líneas que siguen. No obstante, de aquí en adelante se opta por facilitar el desglose de categorías, y no sólo en lo referente a la etnia o raza, sino también a la orientación sexual (gay o lesbiana).

85 Sobre este particular, REBOLLO VARGAS aludía en 2018 a que existían en torno a noventa pronunciamientos como estimación total. Se trata, según este autor, de una cifra modesta y nada significativa, lo cual parece evidente incluso con la cifra recién actualizada de ciento treinta y seis pronunciamientos (si bien, en este caso, sólo condenatorios). ReBollo VARgAS, R., "Controversias y propuestas interpretativas sobre la agravante de discriminación por razón de odio», en LANDA GorostizA, J.M./Garro Carrera, E. (coords.): Delitos de odio. Derecho comparado y regulación española, Tirant lo Blanch, Valencia, 2018, pp. 208-209. 
de género (y, recordemos, desde el 1 de julio de 2015 en adelante). De atenernos exclusivamente al marco temporal del primer trienio aplicativo del género como circunstancia agravante, son treinta y cuatro $(57,63 \%)$ las sentencias condenatorias o confirmatorias de condena de un total de cincuenta y nueve. Es decir, según estos datos, más de la mitad de todas las sentencias condenatorias o confirmatorias de condena dictadas en España desde el 1 de julio de 2015 y hasta el 1 de julio de 2018 fueron agravadas por razón de género.

Es discutible que esta información trascienda y refleje una realidad sociológica descompensada respecto a la victimización por otras categorías protegidas, que además tienen casi un cuarto de siglo de recorrido legislativo. Lo que es incontestable es que el género, para bien o para mal, ha tenido un impacto nunca antes visto en la tasa de condenas sobre delitos de odio sensu stricto en España. Por año y por categoría/s protegida/s ${ }^{86}$, es posible exponer a continuación una relación de sentencias condenatorias firmes (incluidas aquellas que hayan podido confirmarse, en el sentido de estimar concurrente la agravante, más allá del 1 de julio de 2018) sobre la aplicabilidad que ha merecido la agravante desde la entrada en vigor del Código penal (mayo de 1996) y hasta el 1 de julio 2018 (fin del primer trienio aplicativo de la agravante por razones de género):

1996 Ninguna (0). Total (0).

1997 Ninguna (0). Total (0).

1998 Ninguna (0). Total (0).

1999 Ideología (1) ${ }^{87}$. Total (1).

2000 Ideología/Formas de pensar y entender la vida (1) ${ }^{88}$; Nación/ Raza: negro (1) ${ }^{89}$; Sin determinar o no evidente (1) ${ }^{90}$. Total (3).

2001 Ninguna (0). Total (0).

2002 Ideología/Creencias (1) ${ }^{91}$; Orientación sexual: gay (2) ${ }^{92}$; Orientación sexual: lesbiana (1) ${ }^{93}$; Raza: árabe (2) ${ }^{94}$; Raza: negro (2) ${ }^{95}$. Total (8).

2003 Raza: árabe (1) ${ }^{96}$; Raza: negro (1) ${ }^{97}$. Total (2).

86 Para conocer mejor los criterios adoptados a fin de reflejar la relación de categorías que sigue a continuación, manteniendo cierta uniformidad y coherencia, véase el apartado «II. Metodología» supra.

87 SAP de Álava 172/1999, de 13 de octubre.

88 SAP de las Islas Baleares 134/2000, de 30 de junio.

89 SAP de Tarragona, de 15 de junio de 2000.

$90 \quad$ SAP de Barcelona, de 30 de noviembre de 2000.

91 STS 713/2002, de 24 de abril.

92 SAP de Madrid 529/2002, de 13 de mayo; STS 1341/2002, de 17 de julio.

93 SJP N 13 de Barcelona 397/2002, de 29 de noviembre.

94 SAP de Barcelona, de 22 de julio de 2002; SAP de Lleida 606/2002, de 13 de septiembre.

95 SAP de Lleida 360/2002, de 4 de junio; SAP de Madrid 302/2002, de 18 de junio.

96 STS 364/2003, de 13 de marzo.

97 SAP de Madrid 20/2003, de 21 de enero. 
2004 Ideología (1); Orientación sexual: gay (1) ${ }^{98}$; Raza: árabe (2) ${ }^{99}$; Sin determinar o no evidente (1) ${ }^{100}$. Total (5).

2005 Creencias (1) ${ }^{101}$; Discapacidad (1) ${ }^{102}$; Raza: árabe (1) ${ }^{103}$; Sexo (1) ${ }^{104}$. Total (4).

2006 Ideología (2) ${ }^{105}$; Raza: negro (2) ${ }^{106}$. Total (4).

2007 Etnia: latino (1) ${ }^{107}$; Inmigrantes/Racismo (1) ${ }^{108}$; Orientación sexual: gay (1) ${ }^{109}$; Raza: negro (1) ${ }^{110}$. Total (4).

2008 Etnia: gitano (1) ${ }^{111}$; Ideología (1) ${ }^{112}$; Origen étnico (1) ${ }^{113}$; Raza: árabe (1) ${ }^{114}$; Raza: negro (1) ${ }^{115}$. Total (5).

2009 Discapacidad (1) ${ }^{116}$; Etnia: latino (1) ${ }^{117}$; Ideología (3) ${ }^{118}$; Raza: árabe (2) ${ }^{119}$; Raza: negro (1) ${ }^{120}$; Sin determinar o no evidente (1) ${ }^{121}$. Total (9).

2010 Etnia: gitano/Nacionalidad/Raza: árabe (1) ${ }^{122}$; Etnia: latino/Xenofobia (1) ${ }^{123}$; Ideología (2) ${ }^{124}$; Ideología/Nación (1) ${ }^{125}$; Racismo (1) ${ }^{126}$; Raza: negro (2) ${ }^{127}$. Total (8).

98 SAP de Madrid 43/2004, de 10 de mayo.

99 SAP de Huelva 278/2004, de 16 de noviembre; SAP de Barcelona 1210/2004, de 16 de diciembre.

100 SAP de Barcelona 827/2004, de 23 de julio.

101 SAP de Madrid 189/2005, de 22 de abril.

102 SAP de Málaga 539/2005, de 27 de septiembre.

103 SAP de Castellón 5/2005, de 25 de abril.

104 SJP N 8 de Valencia 151/2005, de 21 de abril.

105 SAP de Barcelona, de 3 de noviembre de 2006; STS 1145/2006, de 23 de noviembre.

106 SAP de Barcelona 342/2006, de 7 de abril; SAP de Cádiz 123/2006, de 12 de junio.

107 SAP de Madrid 82/2007, de 16 de marzo.

108 SAP de Las Islas Baleares 102/2007, de 18 de junio.

109 SAP de A Coruña 66/2007, de 19 de febrero.

110 SAP de Madrid 270/2007, de 13 de julio de 2007.

111 SAP de Huelva 102/2008, de 3 de septiembre.

112 SAP de Valladolid 58/2008, de 10 de abril

113 SAP de Barcelona 115/2008, de 28 de mayo.

114 SAP de Barcelona 238/2008, de 10 de marzo.

115 SAP de Zaragoza 25/2008, de 16 de enero.

116 SAP de Madrid 900/2009, de 3 de noviembre.

117 SJP N ${ }^{\circ} 22$ de Barcelona 412/2009, de 29 de octubre.

118 SAP de Zaragoza 110/2009, de 4 de febrero; SAP de Barcelona 221/2009, de 19 de junio; SAP de Barcelona 135/2009, de 27 de julio.

119 SAP de Barcelona 99/2009, de 28 de enero; SAP de Barcelona 180/2009, de 27 de febrero.

120 SAP de Madrid 307/2009, de 29 de septiembre.

121 SAP de Barcelona 354/2009, de 26 de mayo.

122 SAP de Barcelona 24/2010, de 15 de enero.

123 SAP de Madrid 500/2010, de 17 de diciembre.

124 STS 360/2010, de 22 de abril; SAP de A Coruña 302/2010, de 19 de julio.

125 SAP de A Coruña 54/2010, de 29 de noviembre.

126 SAP de Valencia 698/2010, de 26 de octubre.

127 SAP de Madrid 717/2010, de 28 de junio; SAP de Barcelona 940/2010, de 16 de noviembre. 
2011 Ideología (1) ${ }^{128}$; Ideología/Raza: negro (1) ${ }^{129}$; Orientación sexual: gay (1) ${ }^{130}$; Raza: negro (1) ${ }^{131}$. Total (4).

2012 Raza: negro (2) ${ }^{132}$. Total (2).

2013 Ideología (1) ${ }^{133}$; Raza: árabe (1) ${ }^{134}$; Raza: negro (1) ${ }^{135}$. Total (3). 2014 Etnia: latino (1) ${ }^{136}$; Ideología (3) ${ }^{137}$; Orientación sexual: gay (3) ${ }^{138}$; Raza: árabe (1) ${ }^{139}$; Raza: negro (1) ${ }^{140}$. Total (9).

2015 Ideología (2) ${ }^{141}$; Orientación sexual: gay (2) ${ }^{142}$; Raza: árabe (1) ${ }^{143}$; Raza: árabe/Raza: negro (1) ${ }^{144}$; Raza: negro (3) ${ }^{145}$; Sexo (1) ${ }^{146}$; Xenofobia (2) ${ }^{147}$. Total (12).

2016 Etnia: latino/Discapacidad/Raza: negro/Xenofobia (1) ${ }^{148}$; Género (4) ${ }^{149}$; Ideología (2) ${ }^{150}$;Orientación sexual: gay (3) ${ }^{151}$; Raza: árabe

128 STS 815/2011, de 11 de julio.

129 SAP de Madrid 306/2011, de 5 de octubre.

130 SAP de Sta. Cruz de Tenerife 50/2011, de 25 de enero.

131 SAP de Madrid 136/2011, de 29 de noviembre. Consta también auto de inadmisión del recurso de casación (TS 1267/2012, de 21 de junio).

132 SAP de Sevilla 10/2012, de 12 de marzo; SAP de Huesca 141/2012, de 13 de septiembre.

133 STS 1037/2013, de 27 de diciembre.

134 SAP de Barcelona 571/2013, de 8 de julio.

135 SJP N ${ }^{\circ} 11$ de Valencia 105/2013, de 21 de marzo.

136 SJP N $^{\circ} 11$ de Valencia 3/2014, de 10 de enero.

137 SJP N 28 de Barcelona 187/2014, de 22 de abril; SJI N 1 de Albacete 439/2014, de 9 de octubre; SAP de Barcelona, de 30 de octubre de 2014.

138 SJP N 22 de Barcelona 125/2014, de 21 de marzo; SJP N 4 de Barcelona 209/2014, de 7 de mayo; SJP N 3 de Vilanova i la Geltrú 481/2014, de 27 de octubre.

139 SJI No 4 de Coslada, de 9 de julio de 2014.

140 SAP de Valladolid 234/2014, de 22 de mayo.

141 STS 314/2015, de 4 de mayo. Consta desestimación del incidente de nulidad de actuaciones (Auto del TS, de 15 de octubre); SAP de León 451/2015, de 6 de octubre.

142 SAP de Huelva 151/2015, de 23 de septiembre; SJP N 1 de Barcelona, de 19 de noviembre de 2015.

143 SAP de Sevilla 355/2015, de 30 de junio.

144 SAP de A Coruña 334/2015, de 2 de junio.

145 SJP N ${ }^{\circ} 1$ de Barcelona, de 16 de marzo de 2015; SJP N 1 de Logroño 248/2015, de 22 de junio; SAP de Las Islas Baleares 142/2015, de 12 de noviembre.

146 SJP N $^{\circ} 9$ de Barcelona 287/2015, de 10 de junio.

147 SJP N 26 de Barcelona 392/2015, de 22 de octubre; SAP de Barcelona, de 4 de noviembre de 2015

148 SAP de Córdoba 292/2016, de 17 de junio.

149 SAP de Castellón 162/2016, de 20 de junio; SAP de Vizcaya 53/2016, de 14 de julio; SAP de Valladolid 240/2016, de 25 de julio; SAP de Castellón 232/2016, de 11 de octubre (consta auto de inadmisión del recurso de casación del TS 707/2017, de 20 de abril).

150 STS 983/2016, de 11 de enero (constan otras resoluciones judiciales posteriores: SAP de Madrid 61/2016, de 19 de febrero; Auto del TS, de 4 de mayo de 2017; Autos del TC 159/2017, 156/2017, 160/2017 y 157/2017, de 21 de noviembre); SAP de León 369/2016, de 20 de julio; SAP de Barcelona 835/2016, de 5 de diciembre.

151 SJP N 2 de Valencia 145/2016, de 12 de abril; SJP N ${ }^{\circ} 10$ de Barcelona 224/2016, de 25 de abril; SAP de Valencia 447/2016, de 28 de junio. 
(2) $)^{152}$; Raza: asiático/Xenofobia (1) ${ }^{153}$, Raza: negro (2) ${ }^{154}$; Transexual (1) ${ }^{155}$; Xenofobia (1) ${ }^{156}$. Total (17).

2017 Etnia: magrebí/Raza: árabe (1) ${ }^{157}$; Género (11) ${ }^{158}$; Ideología $\left(1^{159}\right.$; Orientación sexual: gay (1) ${ }^{160}$; Sexo (1) ${ }^{161}$; Xenofobia (1) ${ }^{162}$. Total (16).

152 SAP de Zaragoza 55/2016, de 16 de marzo; SAP de Valladolid 264/2016, de 8 de noviembre.

153 SJP N ${ }^{\circ} 1$ de Barcelona, de 19 de enero de 2016.

154 SJP N 1 de Valencia 134/2016, de 10 de marzo; SAP de Barcelona 211/2016, de 15 de marzo

155 SJP N 7 de Málaga 332/2016, de 18 de octubre.

156 SJP N ${ }^{\circ} 6$ de Barcelona 64/2016, de 18 de febrero.

157 SAP de Tarragona 451/2017, de 27 de diciembre (confirmada por STS 634/2018, de 12 de diciembre).

158 SAP de Asturias 18/2017, de 20 de enero; SAP de Lleida 56/2017, de 7 de febrero; SAP de Valladolid 69/2017, de 21 de febrero; SAP de Valencia 145/2017, de 3 de marzo; SAP de Sevilla 163/2017, de 31 de marzo; SAP de Valladolid 144/2017, de 2 de mayo; SAP de A Coruña 213/2017, de 9 de mayo; SAP de Valladolid 175/2017, de 29 de mayo (consta auto de inadmisión del recurso de casación 209/2018, de 11 de enero); STSJ de Canarias 7/2017, de 26 de junio; SAP de Segovia 18/2017, de 16 de noviembre (confirmada la concurrencia de la agravante por STS 420/2018, de 25 de septiembre, ya que se revoca la STSJ de Castilla y León 8/2018, de 8 de marzo, que dejó en su momento sin efecto la aplicación de la misma); SAP de Zaragoza 350/2017, de 30 de noviembre (si bien la STSJ de Aragón 17/2018, de 4 de mayo revocó la aplicación de la agravante por motivos discriminatorios de género, ésta se introduce nuevamente a través del recurso de casación interpuesto y resuelto por STS 707/2018, de 15 de enero).

159 SAP de Madrid 517/2017, de 11 de diciembre. Aclaración sobre otra sentencia excluida del cómputo: La STS 983/2016, de 11 de enero de 2017, correspondiente al conocido como "caso Blanquerna», ha quedado recientemente anulada por el TC. La STC $1 / 2020$, de 14 de enero, declara que se han vulnerado los derechos a un proceso con todas las garantías y a la presunción de inocencia (art. 24.2 CE) de todos los demandantes en el extremo relativo a la aplicación de la agravante de haber cometido el delito por discriminación ideológica (art. 22.4 CP), por lo que los restablece en sus derechos y declara la nulidad de, entre otras resoluciones, la STS 983/2016, de 11 de enero de 2017, retrotrayendo las actuaciones al momento anterior al de la sentencia anulada. De esta forma, nos remontaríamos a la SAP de Madrid 61/2016, de 19 de febrero, la cual estima que no concurre en los acusados la agravante de ejecutar los hechos por motivos ideológicos (FJ 5).

160 SAP de Asturias 7/2017, de 13 de enero.

161 SAP de Castellón 45/2017, de 20 de febrero.

162 SAP de Lleida 119/2017, de 28 de marzo. 


\section{Género (19) ${ }^{163}$; Orientación sexual: gay (1) ${ }^{164}$. Total (20).}

En suma, con el riesgo de solapamientos ya anunciado ${ }^{165}$ pero respetando y manteniendo la identificación de categorías establecida - expresa o implícitamente- por los jueces y tribunales, una lectura entre líneas de cada resolución hace posible reflejar una síntesis de prevalencia de aparición: Género (34), Ideología (24), Raza: negro (24), Raza: árabe (17), Orientación sexual: gay (15), Xenofobia (7), Etnia: latino (5), Discapacidad (3), Sexo (3), Sin determinar o no evidente (3), Creencias (2), Etnia: gitano (2), Nación (2), Racismo (2), Etnia: magrebí (1), Formas de entender la vida (1), Inmigrantes (1), Nacionalidad (1), Orientación sexual: lesbiana (1), Raza: asiático (1) y Transexual (1).

163 SAP de Valladolid 11/2018, de 16 de enero; SAP de Asturias 12/2018, de 18 de enero; SAP de Cádiz 16/2018, de 19 de enero; SAP de Cuenca 4/2018, de 6 de febrero; SAP de Asturias 40/2018, de 7 de febrero; SAP de Castellón 46/2018, de 12 de febrero; SAP de Madrid 74/2018, de 13 de febrero (el Alto Tribunal entraría finalmente a examinar el fondo de asunto y mantendría el sentido de la agravante a través de la STS 12/2020, de 23 de enero); STSJ de Asturias 4/2018, de 2 de marzo (más adelante, por STS 92/2019, de 20 de febrero, el Alto Tribunal anula parcialmente dicha resolución pero mantiene los pronunciamientos del fallo condenatorio que conciernen a la agravante por motivos discriminatorios de género); SAP de Valencia 147/2018, de 8 de marzo (confirmada por STSJ de la Comunidad Valenciana 89//2018, de 27 de julio e inadmisión del recurso de casación por auto del TS 413/2019, de 21 de marzo); SAP de Asturias 69/2018, de 9 de marzo (confirmada y firme tras la STSJ de Asturias 19/2018, de 17 de julio); SAP de Madrid 211/2018, de 19 de marzo (confirmada por STS 565/2018, de 19 de noviembre); STSJ de Castilla La Mancha 5/2018, de 23 de marzo; STSJ de Madrid 44/2018, de 12 de abril (confirmada por STS 597/2018, de 27 de noviembre); SAP de Bizkaia 34/2018, de 26 de abril (confirmada por STSJ 40/2018, de 15 de octubre); SAP de Valencia 251/2018, de 7 de mayo (confirmada por STS 117/2019, de 6 de marzo, si bien se modifica la calificación de los hechos y se pasa a agravar otro delito); SAP de Burgos 179/2018, de 11 de mayo (confirmada primero por STSJ de Castilla y León 35/2018, de 28 de septiembre, y después por STS 201/2019, de 10 de abril); SAP de Cantabria 204/2018, de 7 de junio (confirmada por STSJ de Cantabria 13/2018, de 17 de octubre, en lo que se refiere a la agravante); SAP de Asturias 274/2018, de 12 de junio (agravante por motivos discriminatorios de género objeto de recurso y confirmada por STSJ de Asturias 28/2018, de 7 de diciembre, que también se mantendrá tras la STS 351/2019, de 9 de julio); STSJ de la Comunidad Valenciana 72/2018, de 29 de junio (confirmada por STS 99/2019, de 26 de febrero).

164 SAP de Barcelona 212/2018, de 26 de marzo (confirmada por STSJ de Cataluña 62/2019, de 13 de mayo).

165 Nuevamente, nos remitimos aquí al apartado «II. Metodología» supra. 


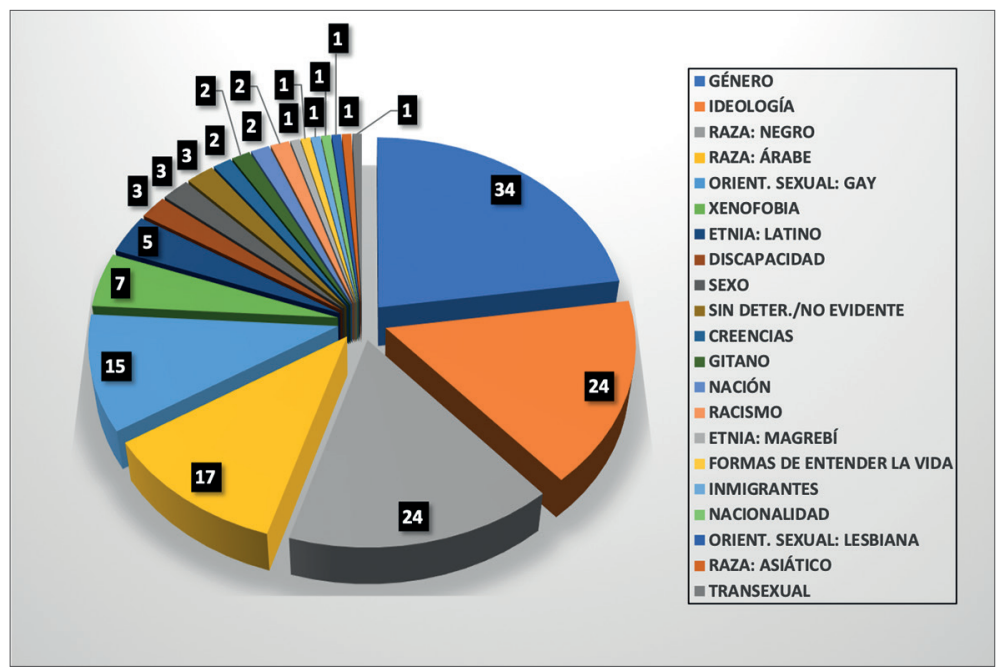

Figura I. Prevalencia de aparición de categorías, 1996-2018.

En resumen, y como ya se ha indicado, el género agrava la responsabilidad penal en un cuarto del total de ciento treinta y seis resoluciones condenatorias o confirmatorias de condena (25\%). En cuanto al cómputo general de todas las categorías que se han empleado o que están involucradas como posibles agravaciones de la responsabilidad penal en las ciento treinta y seis resoluciones analizadas, el género representa la categoría dominante. Pues bien, según estos primeros datos obtenidos para el caso español ${ }^{166}$, es posible afirmar ya que ha existido una notable sobreexposición de la mujer en la criminalidad por odio.

4.1.1. Sentencias condenatorias o confirmatorias de condena dentro del primer trienio aplicativo de referencia (2015-2018)

Con carácter previo a construir el perfil de víctima y agresor o a considerar la tipología delictiva exacta a la que se anuda la agravan-

166 En los subepígrafes que siguen, «4.1.1. Sentencias condenatorias o confirmatorias de condena dentro del primer trienio aplicativo de referencia (2015-2018)" y «4.1.2. Actualización de datos (2018-2020)", se ofrece al lector un desglose de datos ampliado y mucho más detallado en torno a todas aquellas sentencias condenatorias (o confirmatorias de condena) en que algún delito se haya visto agravado, precisamente, por esta categoría de género de entre todas las que integran el art. 22.4 CP. Nótese también que tales subepígrafes serán eminentemente descriptivos, reservándose para un posterior apartado conclusivo (véase «V. Conclusiones») algunas consideraciones de interés en torno a los datos que en ellos obran. 
te, atenderemos primero a la fecha y lugar de comisión de los hechos delictivos. Según la fecha de comisión de los hechos que han resultado agravados ${ }^{167}$, más de la mitad se produjeron en $2016(19-54,28 \%)$, seguido de $2015(15-42,85 \%)$ y, por último, 2017 (1 - 2,86\%). En cuanto al lugar de comisión de los hechos ${ }^{168}$, destaca muy especialmente el domicilio $(22-56,41 \%)$, sea de la víctima/agresor, común o de un tercero. Tras esta localización, los siguientes escenarios delictivos adquieren notoriedad: calle $(5-12,82 \%)$, nuevas tecnologías (3 $7,69 \%)$, tienda y otros establecimientos $(3-7,69 \%)$, portal $(2-5,13 \%)$, carretera $(1-2,56 \%)$, caseta de campo $(1-2,56 \%)$, coche $(1-2,56 \%)$ y descampado $(1-2,56 \%)$.

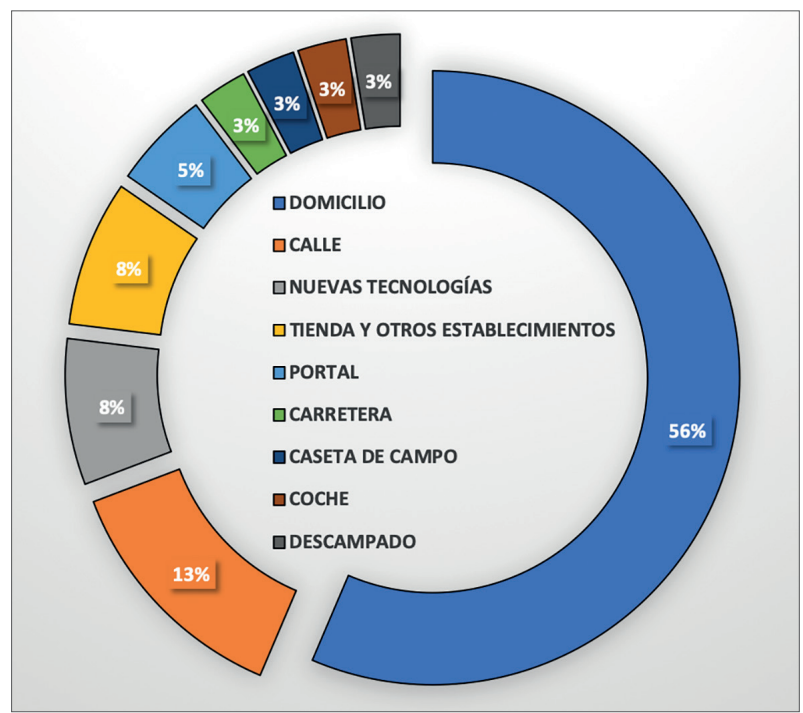

Figura II. Distribución de los delitos por lugar de comisión, 2015-2018.

Respecto a la víctima, de entre las treinta y cuatro sentencias que agravan por razón de género, en 15 resultó ser expareja sentimental del agresor en el momento de los hechos (44,12\%), en 10 esposa $(29,41 \%)$, en 6 pareja sentimental $(17,65 \%)$ y en 3 exesposa $(8,82 \%)$.

167 Nótese que en una de las sentencias, al ser un delito continuado de agresión sexual por más de treinta años de duración hasta que se denuncian los hechos en 2016, el caso consta reflejado tanto en 2015 como en 2016. Es decir, se contabiliza por partida doble la fecha de comisión de los hechos de una sentencia a efectos del cómputo global.

168 Nótese que de cada sentencia han podido derivar más de un hecho delictivo y que éstos se hayan cometido en lugares diferentes, o que la acción delictiva y el resultado típico puedan corresponderse con lugares diferentes, o que incluso un mismo delito sea consumado en diferentes lugares por continuidad delictiva. Todos estos supuestos tendrán reflejo en el cómputo general. 
La edad de las víctimas se recoge sólo en 15 casos, si bien en otros 7 ha sido posible conocer este dato por la repercusión mediática de algunos de ellos (en total, 64,70\%). Por franjas de edad, de 18 a 30 años es donde se concentra el mayor número de mujeres víctimas $(8-23,53 \%)$ de algún delito de entre los contenidos en el total de las sentencias analizadas. La segunda franja sería la de 31 a 45 años (7 - 20,59\%), seguida de la de 46 a 65 años $(5-14,70 \%)$. Finalmente restaría la franja de víctimas menores de 18 años $(1-2,94 \%)$ y la de mayores de 65 años $(1-2,94 \%)$. En 12 casos no se conoce la edad de la víctima $(35,29 \%)$.

Respecto al agresor, su edad se recoge en 29 casos, si bien en otros 2 ha sido posible conocer este dato por la repercusión mediática de algunos de ellos (en total, 91,18\% ${ }^{169}$. Por franjas de edad, de 46 a 65 años es donde se concentra el mayor número de agresores $(12-33,33 \%)$, inmediatamente seguida de la franja de 31 a 45 años $(11-30,55 \%)$. Tras ellas destaca la de 18 a 30 años $(7-19,44 \%)$ y la de mayores de 65 años $(3-8,33 \%)$ en último lugar. No se conoce la edad del agresor en 3 casos $(8,33 \%)$. La nacionalidad del autor consta en 30 casos $(88,23 \%)$. El autor era español en 23 casos $(67,65 \%)$ y extranjero en $7(20,59 \%)$. Se desconoce la nacionalidad de autor en 4 casos $(11,76 \%)$.

Por lo demás, constan 40 delitos comunes agravados en el conjunto de las treinta y cuatro sentencias condenatorias o confirmatorias de condena. En concreto, encontramos el asesinato (14 - 35\%) como el delito más veces agravado por razones de género. En cuanto al grado de ejecución alcanzado, el 71,43\% (10) de los delitos de asesinato constan como consumados y el $28,57 \%$ (4) intentados. En segundo lugar, se contempla el delito de homicidio $(8-20 \%)$, de entre los cuales un $87,50 \%$ (7) serían intentados y sólo un $12,50 \%$ (1) consumados. En tercer lugar radica la agresión sexual $(5-12,50 \%)$ y las amenazas $(5-$ $12,50 \%)$. En cuarto lugar están las lesiones $(2-5 \%)$. Finalmente, constan el allanamiento de morada $(1-2,50 \%)$, las coacciones $(1-2,50 \%)$, los daños $(1-2,50 \%)$, la detención ilegal $(1-2,50 \%)$, el incendio (1 $2,50 \%)$ y el maltrato habitual $(1-2,50 \%)$.

169 Nótese que en uno de los casos, al ser un delito continuado de agresión sexual por más de treinta años de duración hasta que se denuncian los hechos en 2016, el agresor aparecerá reflejado en tres franjas de edad diferentes. Es decir, se contabilizará tres veces, por lo que el cómputo será sobre un total de treinta y seis agresores en treinta y cuatro sentencias. En el caso de la víctima no se ha tenido esto en cuenta puesto que se desconoce su edad. 


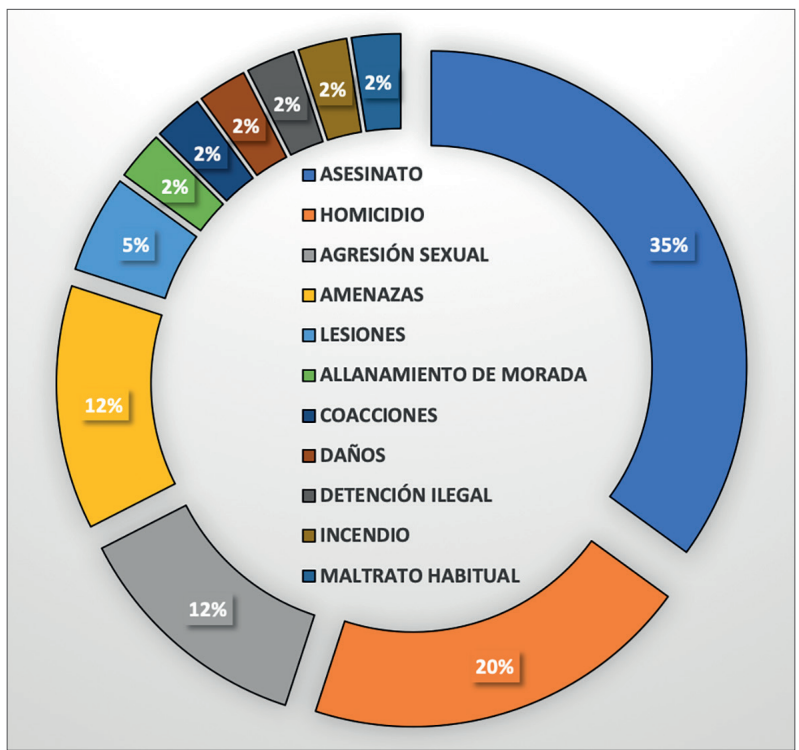

Figura III. Distribución de los delitos comunes agravados por categoría delictiva, 2015-2018.

\subsubsection{Actualización de datos (2018-2020)}

En total, quince casos con agravaciones por razón de género traen causa del tramo temporal ya examinado (1 de julio de 2015-1 de julio de 2018), confirmando resoluciones condenatorias que se dictaron durante el mismo o, en otro caso, manteniendo la concurrencia de la agravante. El Tribunal Supremo entraría a resolver sobre el fondo del asunto en diez de tales casos. En el nuevo tramo temporal que nos ocupa (1 de julio de 2018-1 de julio de 2020), encontramos otras cinco nuevas resoluciones del Tribunal Supremo que entra a conocer sobre el fondo y resuelve estimando correcta la apreciación de las razones de género como agravante anudada a algún delito ${ }^{170}$. Por tanto, hasta en quince ocasiones el Tribunal Supremo ha entrado a examinar la concurrencia de la agravante por motivos discriminatorios de género estimándola adecuada y conforme a derecho.

En general, atendiendo ahora también a la jurisprudencia menor, se han dictado cincuenta y una nuevas condenas (o confirmaciones de condena) entre el 1 de julio de 2018 y el 1 de julio de 2020 que han agravado por razones de género. Ello sin contabilizar las quince senten-

170 STS 339/2019, de 3 de julio; STS 471/2019, de 14 de octubre; STS 663/2019, de 14 de enero; STS 136/2020, de 8 de mayo; STS 257/2020, de 28 de mayo. 
cias relativas a casos que derivan del periodo anterior ${ }^{171}$. Ajustándonos a los cincuenta y un nuevos casos identificados siguiendo el método de consulta exhaustiva en las bases de datos, 4 se acabaron resolviendo en $2018(7,84 \%)^{172}$, 30 en $2019(58,82 \%)^{173}$ y 17 en $2020(33,33 \%)^{174}$.

Antes bien, conviene tener presente que si cincuenta y una sentencias condenatorias agravan por razones de género en este nuevo tramo temporal, el cual complementa la información anteriormente facilitada, constan además ocho sentencias condenatorias (o confirmatorias de condena) por otras categorías protegidas. Por años y categorías, una única sentencia fue dictada en 2018 (Xenofobia/Raza: árabe/Etnia: magrebí) ${ }^{175}$, cinco lo fueron en 2019 (dos relacionadas con Ideología, una con $\mathrm{Na}$ -

171 Si bien en el siguiente apartado sí que se entrará a conocer cómo han resuelto estas quince resoluciones la cuestión acerca del fundamento de la agravante, a los efectos de actualización que aquí nos ocupan carecería de sentido duplicar la información ya facilitada en el anterior epígrafe (p.ej.: fecha y lugar de comisión de los hechos, relación de la víctima con su agresor, edad de víctima y de autor, nacionalidad del autor, delito/s concreto/s agravado/s por el art. 22.4 CP, y grado de ejecución alcanzado en los delitos más graves).

172 STSJ de Galicia 25/2018, de 27 de septiembre; STSJ de Cantabria 17/2018, de 16 de noviembre (consta también Auto del TS 704/2019, de 11 de julio, que inadmite recurso de casación formulado); SAP de Barcelona 928/2018, de 27 de noviembre; SAP de León $544 / 2018$, de 18 de diciembre.

173 STSJ de Galicia 13/2019, de 31 de enero (consta también Auto del TS 750/2019, de 11 de julio, que inadmite recurso de casación formulado); SAP de Asturias 120/2019, de 22 de marzo; STSJ de Aragón 23/2019, de 29 de abril; SAP de Barcelona 275/2019, de 2 de mayo; STSJ de Asturias 22/2019, de 13 de mayo (consta también Auto del TS 266/2020, de 6 de febrero, que inadmite recurso de casación formulado); STSJ de Canarias 27/2019, de 20 de mayo; STSJ de Cataluña 64/2019, de 20 de mayo; SAP de Sta. Cruz de Tenerife 212/2019, de 28 de mayo; SAP de Sevilla 264/2019, de 29 de mayo; STS 339/2019, de 3 de julio; SAP de Granada 324/2019, de 27 de agosto; SAP de Madrid 575/2019, de 26 de septiembre; STSJ de Castilla y León 53/2019, de 27 de septiembre; SAP de A Coruña 366/2019, de 2 de octubre; STSJ de Madrid 195/2019, de 2 de octubre; STS 471/2019, de 14 de octubre; SAP de Murcia 327/2019, de 16 de octubre; SAP de Madrid 602/2019, de 22 de octubre; SAP de Castellón 370/2019, de 25 de octubre; STSJ de Canarias 58/2019, de 28 de octubre; SAP de Albacete 336/2019, de 11 de noviembre; SAP de A Coruña 450/2019, de 12 de noviembre; STSJ de Cataluña 140/2019, de 14 de noviembre; STSJ de Canarias 64/2019, de 20 de noviembre; SAP de Palencia 27/2019, de 22 de noviembre; SAP de Granada 504/2019, de 16 de diciembre; SAP de Madrid 795/2019, de 16 de diciembre; SAP de Lleida 482/2019, de 19 de diciembre; SAP de Pontevedra 2/2020, de 30 de diciembre de 2019; SAP de Asturias 453/2019, de 30 de diciembre.

174 STS 663/2019, de 14 de enero; SAP de Madrid 41/2020, de 20 de enero; SAP de Sevilla 2/2020, de 4 de febrero; SAP de Las Palmas 45/2020, de 13 de febrero; SAP de Madrid 124/2020, de 14 de febrero; SAP de Sta. Cruz de Tenerife 42/2020, de 14 de febrero; SAP de Lugo 30/2020, de 19 de febrero; SAP de Madrid 128/2020, de 24 de febrero; SAP de Barcelona 6/2020, de 24 de febrero; SAP de Madrid 151/2020, de 2 de marzo; STSJ de La Rioja 2/2020, de 25 de marzo; STSJ de Aragón 27/2020, de 22 de abril; STS 136/2020, de 8 de mayo; SAP de Cuenca 48/2020, de 8 de mayo; SAP de Zaragoza 120/2020, de 25 de mayo; STS 257/2020, de 28 de mayo; SAP de Les Illes Balears 2/2020, de 10 de junio.

175 SAP de Cádiz 163/2019, de 20 de mayo. 
ción/Xenofobia, una con Orientación sexual: gay y otra con Racismo) ${ }^{176}$, y otras dos en 2020 (una relacionada con Orientación sexual: gay y otra con Raza: negro/Nación) ${ }^{177}$. En resumen, sólo el 13,56\% de los cincuenta y nueve nuevos casos agravan por una característica identitaria ajena al género, estando este último presente en el $86,44 \%$ restante de los casos. Se mantiene - y, si acaso, se agudiza- la omnipresencia del género a juzgar por los datos obtenidos y que han sido devueltos por las bases de datos legales de referencia.

En este punto, atenderemos ya al análisis de los cincuenta y un nuevos casos que contienen la agravante por motivos discriminatorios de género. Según la fecha de comisión de los hechos que han resultado agravados ${ }^{178}$, casi la mitad se produjeron en 2017 ( $\left.25-47,17 \%\right)$, seguido de $2018(13-24,53 \%), 2016(12-22,64 \%), 2019(2-3,77 \%)$ y, por último, 2015 (1 - 1,89\%). En cuanto al lugar de comisión de los hechos ${ }^{179}$, destaca muy especialmente el domicilio $(32-59,26 \%)$, sea de la víctima/ agresor, común o de un tercero. Tras esta localización, los siguientes escenarios delictivos adquieren notoriedad: calle $(6-11,11 \%)$, coche (3-5,55\%), bar/establecimiento $(3-5,55 \%)$, pista forestal/zona boscosa $(2-3,70 \%)$, portal $(2-3,70 \%)$, casa deshabitada en construcción (1 $1,85 \%)$, caseta de campo $(1-1,85 \%)$, cochera $(1-1,85 \%)$, pensión (1 $-1,85 \%)$, poblado chabolista $(1-1,85 \%)$ y rellano de escalera de centro comercial $(1-1,85 \%)$.

176 SAP de Zaragoza 427/2019, de 20 de noviembre; SAP de Barcelona 840/2019, de 20 de diciembre; STSJ de Castilla y León 66/2019, de 25 de noviembre; SJP N 2 de Granollers 429/2019, de 10 de diciembre; SAP de Valladolid 280/2019, de 17 de diciembre.

177 SAP de Barcelona 5/2020, de 3 de febrero; SAP de Barcelona 120/2020, de 3 de marzo.

178 Nótese que en una de las sentencias, al ser un delito continuado de agresión sexual espaciado en el tiempo por tres años, el caso constará reflejado en 2016, 2017 y 2018 . Es decir, se contabiliza por partida triple la fecha de comisión de los hechos de una sentencia a efectos del cómputo global.

179 Nótese que de cada sentencia han podido derivar más de un hecho delictivo y que éstos se hayan cometido en lugares diferentes, o que la acción delictiva y el resultado típico puedan corresponderse con lugares diferentes, o que incluso un mismo delito sea consumado en diferentes lugares por continuidad delictiva. Todos estos supuestos tendrán reflejo en el cómputo general. 


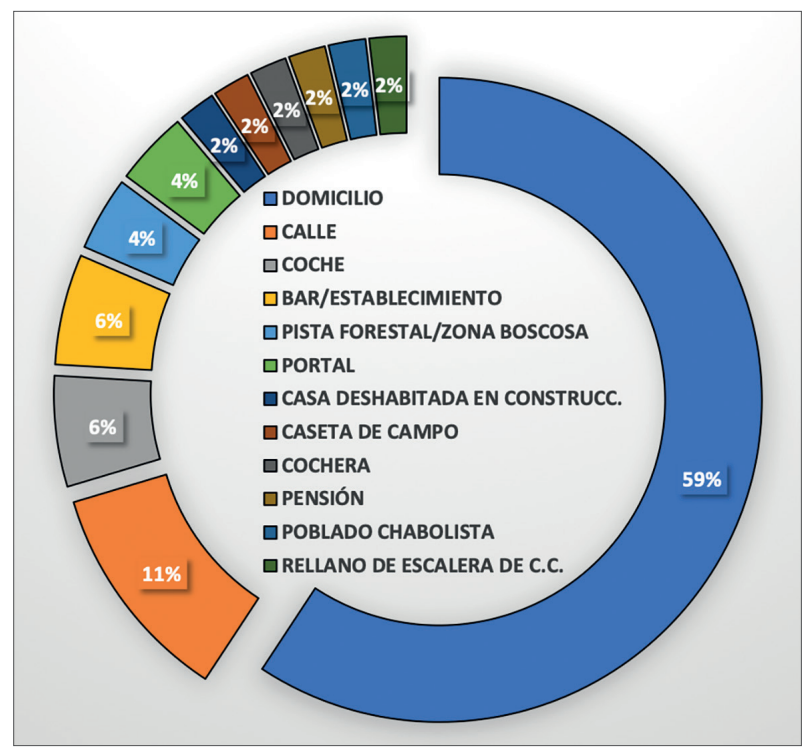

Figura IV. Distribución de los delitos por lugar de comisión, 2018-2020.

Respecto a la víctima, de entre las cincuenta y una sentencias que agravan por razón de género, en 18 resultó ser expareja sentimental del agresor en el momento de los hechos $(35,29 \%)$, en 14 pareja sentimental $(27,45 \%)$, en 11 esposa $(21,57 \%)$, en 4 exesposa $(7,84 \%)$, en 2 no constan datos exactos $(3,92 \%)$, en 1 lo fue el hijo/a en común $(1,96 \%)$ y también en 1 la víctima no mantenía ningún vínculo o relación previa con el agresor $(1,96 \%)$. La edad de las víctimas se recoge sólo en 16 de los casos, si bien en otros 8 ha sido posible conocer este dato por la repercusión mediática de algunos de ellos (en total, 47,06\%). Por franjas de edad, de 31 a 45 años es donde se concentra el mayor número de mujeres víctimas $(13-25,49 \%)$ de algún delito de entre los contenidos en el total de las sentencias analizadas. La segunda franja sería la de 18 a 30 años (7-13,72\%), seguida de la de víctimas menores de 18 años $(2-3,92 \%)$ y víctimas de entre 46 y 65 años $(2-3,92 \%)^{180}$. En 27 casos no se conoce la edad de la víctima $(52,94 \%)$.

Respecto al agresor, su edad se recoge en 47 casos (92,16\%). Por franjas de edad, de 31 a 45 años es donde se concentra el mayor

180 Nótese que en uno de los casos, uno de los delitos involucrados en el mismo se comete siendo pareja sentimental la víctima; otro, en cambio, se comete siendo ya expareja sentimental. Siendo así, se adopta el criterio de que sea el delito más grave el que marque la edad de la víctima a la hora de determinar una cosa o la otra a los efectos que aquí nos ocupan. 
número de agresores ( 27 - 52,94\%), seguida de la franja de 46 a 65 años $(13-25,49 \%)$. Tras ellas destaca la de 18 a 30 años $(6-11,76 \%)$ y la de mayores de 65 años $(1-1,96 \%)$ en último lugar. No se conoce la edad del agresor en 4 casos $(7,84 \%)$. La nacionalidad del autor consta en 48 casos $(94,12 \%)$. El autor era español en 32 casos $(62,74 \%)$ y extranjero en $16(31,37 \%)$. Se desconoce la nacionalidad de autor en 3 casos $(5,88 \%)$.

Por lo demás, constan 63 delitos comunes agravados en el conjunto de las cincuenta y una sentencias condenatorias o confirmatorias de condena. En concreto, encontramos el asesinato $(30-47,62 \%)$ como el delito más veces agravado por razones de género. En cuanto al grado de ejecución alcanzado, el 63,33\% (19) de los delitos de asesinato constan como consumados y el 36,67\% (11) como intentados. En segundo lugar se contempla la agresión sexual $(8-12,70 \%)$ y, tras ella, las amenazas (7-11,11\%). Acto seguido radicarían los homicidios $(5-7,94 \%)$, todos ellos además en grado de tentativa. Después encontramos la detención ilegal $(3-4,76 \%)$ y las lesiones $(3-4,76 \%)$. En un escalón inferior se contemplan el allanamiento de morada $(2-3,17 \%)$ y las coacciones $(2-$ $3,17 \%)$. En último lugar radican el abuso sexual ( $1-1,59 \%)$, el incendio $(1-1,59 \%)$ y el maltrato ocasional $(1-1,59 \%)$.

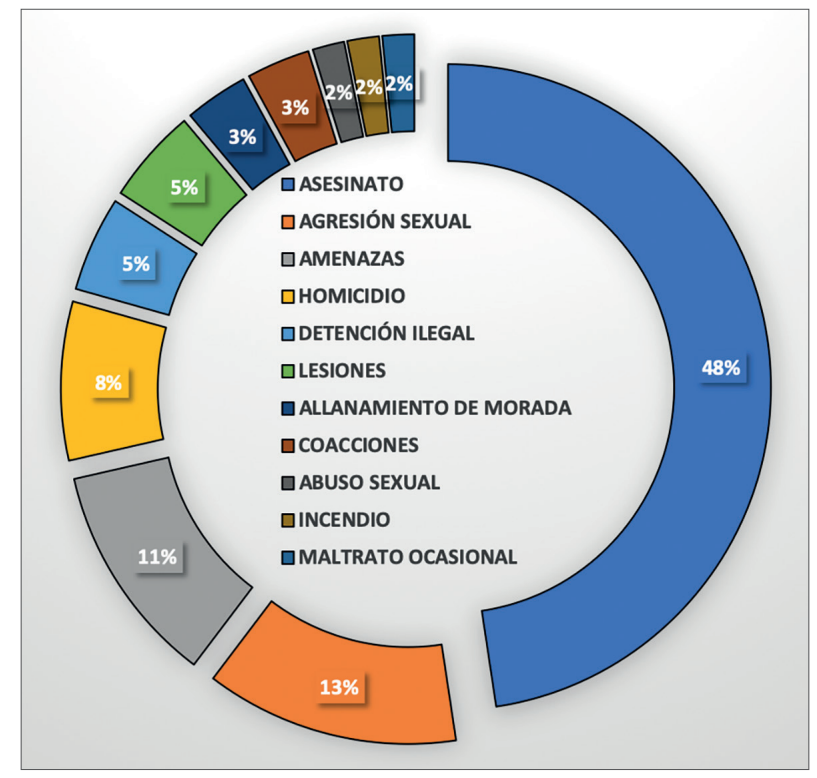

Figura V. Distribución de los delitos comunes agravados por categoría delictiva, 2018-2020. 


\subsection{Evolución y estado de madurez del fundamento de la agravante}

En lo sucesivo se seguirá el mismo esquema de organización de contenidos planteado en el epígrafe anterior. Es decir, los primeros tres años de vida legislativa de la agravante por razones de género enlazan directamente con la época inmediatamente anterior al primer pronunciamiento del Tribunal Supremo sobre este particular. Uno de estos primeros pronunciamientos supuso además un atisbo de cambio en la fundamentación de la agravante, sobre la que cabía colegir cierta regularidad hasta ese momento. Cabe también subrayar que el análisis jurisprudencial que sigue no se centra en los razonamientos jurídicos de toda sentencia donde alguna de las partes haya propuesto aplicar la agravante por razones de género, sino que el alcance será más modesto al estudiar sólo la sentencias condenatorias recaídas, en coherencia lógica con apartados anteriores y con el estudio en su conjunto. Por tanto, la realidad que se pasa a reflejar servirá de indicador muy autorizado para reflexiones generales posteriores.

Por último, mediante la búsqueda del fundamento de la agravante nos referiremos más bien a la naturaleza de las circunstancias modificativas de la responsabilidad penal. Si bien su manido carácter dicotómico (objetivo-subjetivo) plantea no pocos problemas, y de hecho es la propia doctrina la que ha denunciado ese statu quo más artificial que real, su uso parece mantenerse plenamente vigente en la práctica judicial, cuando menos a juzgar por lo recurrente de pronunciamientos en este sentido. Sea como fuere, no se aspira aquí a avivar otros debates paralelos de calado, como podría serlo el plantearnos si verdaderamente el fundamento de la agravante mora exclusivamente en la teoría del delito o si sería pertinente explorar más allá y tender puentes hacia la teoría de la pena ${ }^{181}$.

\subsubsection{Situación que precede a los primeros pronunciamientos del Tribunal Supremo}

La SAP de Castellón 232/2016, de 11 de octubre, primera sentencia condenatoria que entra a razonar jurídicamente el sentido de la aplicación de la agravante por motivos discriminatorios de género, alude al

181 Por ejemplo, rescatando este debate de fondo, SALINERo Alonso menciona que el fundamento dogmático (graduación del injusto o de la culpabilidad) y las razones de índole político-criminal (razones de conveniencia o utilidad) de ciertas circunstancias se hilvanan tan minuciosamente que de su cosido final no sería aconsejable deducir tan claramente dónde radica el peso de su fundamento. Este sería el caso, según la autora, de la agravante por motivos racistas (art. 22.4 CP). En detalle, véase Salinero Alonso, C., Teoría general de las circunstancias modificativas de la responsabilidad criminal y artículo 66 del Código penal, Comares, Granada, 2000, pp. 64-86 (en especial, la nota al pie 96). 
carácter simbólico ${ }^{182}$ que supone el hecho de que a través del género se explicite la tutela reforzada de la dignidad de la mujer. En suma, que despunte y adquiera "carta de naturaleza propia» en su convivencia con otros motivos de índole sexista (el sexo y la orientación o identidad sexual) dentro del art. 22.4 CP. Se parte, de hecho, de la base de que antes de la reforma penal de 2015 existían ya suficientes mecanismos correctores a disposición del aplicador de la ley ${ }^{183}$. Precisamente desplazando estas funciones de filtrado preexistentes, el género dentro del art. 22.4 CP tomaría en gran medida el testigo de tales roles de tutela de la víctima mujer. Primero y muy especialmente sobre «hechos punibles perpetrados por el hombre frente a su pareja o ex-pareja, sea o haya sido legal o de hecho» (FJ 8). Segundo y en términos más vagos, se indica que quedará cubierto otro círculo concéntrico mayor de tutela de víctimas que lo sean por conductas machistas «llevadas a cabo por varones frente a mujeres» (FJ 8). Y lo más importante, que tales conductas vengan guiadas por «(...) la intención, consciente o subconsciente, de expresar su dominio y su trato hacia ellas [mujeres] como seres humanos inferiores» (FJ 8).

Es decir, pareciera como si se impusiera un elemento subjetivo intencional (intención de dominio y superioridad) del injusto ${ }^{184}$ que colorea la concreta forma de la lesión a castigar. Esta intención será necesario probarla mediante juicios de valor o inferencia ${ }^{185}$ lo suficientemente

182 La SAP de A Coruña 177/2018, de 3 de abril, se referirá más bien al «efecto pedagógico» (FJ 2).

183 Es decir, la circunstancia mixta de parentesco (art. $23 \mathrm{CP}$ ) ejercía una función de filtrado para aquellos crímenes machistas sin marca de género en el tipo concreto, existiendo incluso la categoría «sexo» del art. 22.4 CP como válvula de escape excepcional a disposición de jueces y tribunales. Con todo, recuérdese que este apartado no aspira a ahondar en la compatibilidad de tales circunstancias modificativas de la responsabilidad penal, ni a seguir la evolución que tal encaje haya merecido desde estos primeros pronunciamientos en adelante.

184 Esta posición, si bien obedecía a una evolución general muy fluctuante, fue en su momento acogida por el Tribunal Supremo respecto a la aplicación del delito de malos tratos ocasionales (STS 58/2008, de 25 de enero, FJ 4). La exigencia de que se probara la intención de dominación machista en el actuar del autor hace aguas hoy con la objetividad y automatismos aplicativos que subyacen a la presunción iuris tantum de que toda conducta punible del agresor varón frente a su pareja o expareja sea, salvo prueba en contrario, un acto objetivamente expresivo de un trasfondo de dominación machista general fuertemente arraigado en nuestro ámbito cultural (véase, con base en la jurisprudencia constitucional, la STS 856/2014, de 26 de diciembre, FJ 4).

185 Parece conveniente reproducir aquí ciertas aclaraciones del Tribunal Supremo al respecto: «Los juicios de valor sobre intenciones y los elementos subjetivos del delito pertenecen a la esfera del sujeto, y salvo confesión del acusado en tal sentido, solo pueden ser perceptibles mediante juicio inductivo a partir de datos objetivos y materiales probados (STS. 22.5.2001). En esta dirección la STS 1003/2006 de 19.10, considera juicios de inferencia las proposiciones en que se afirma o eventualmente se niega, la concurrencia de un hecho subjetivo, es decir de un hecho de conciencia que, por su propia naturaleza no es perceptible u observable de manera inmediata o directa. Esta conclusión (...) debe deducirse de datos externos y objetivos que consten en el relato fáctico y aun cuando el 
motivados ${ }^{186}$. Sólo aquella agresión que venga acompañada con tintes de dominación y desequilibrio secular de los sexos queda lo suficientemente perfilada como para adicionar el castigo extra que supone la agravante. Será decisivo el examen de hechos anteriores y concomitantes al acto que nos ocupa para determinar la relación de dominación de género (SAP de Cuenca 4/2018, de 6 de febrero, FJ 4). Se dota de un mayor desvalor — subjetivo- de la acción ${ }^{187}$ que deriva del carácter contingente de una agravante ajena al tipo penal.

A primera vista, la SAP de Asturias 18/2017, de 20 de enero, también incide en la necesidad de acreditar la intención de dominio y superioridad sobre la mujer por el hecho de serlo. Pero, según se indica, lo anterior se estima determinante para evidenciar el móvil comisivo, lo cual justificará un mayor reproche penal por razón de una mayor culpabilidad de autor como fundamento último de la agravante (FJ 3) ${ }^{188}$. Por ello queda claro ahora y no se rehúye el hecho de que el acento se pone en

propio juicio de inferencia se incluya también en el relato fáctico como hecho subjetivo es revisable en casación (...). [Y] ello supone que el elemento subjetivo expresado en el hecho probado pertenece a la tipicidad penal y supone una actividad lógica o juicio de inferencia porque como lo subjetivo y personal aparece escondido en los pliegues de la conciencia, puede ser inducido únicamente por datos externos, concluyentes y suficientemente probados en la causa (SSTS. 151/2005 de 27.12, 394/94 de 23.2)» (STS 922/2009, de 30 de septiembre, FJ 1).

186 Así se recoge, entre otras, en: SAP de Valladolid 175/2017, de 29 de mayo, FJ 2; SAP de Asturias 69/2018, de 9 de marzo, FJ 4; SAP de Burgos 179/2018, de 11 de mayo, FJ 7. En otras palabras y según recuerda la STSJ de la Comunidad Valenciana 72/2018, de 29 de junio, «la intención no puede fotografiarse», por lo que «debe de deducirse de los hechos acreditados» (FJ 3). Así entiende que sucede, entre otras, la STSJ de Canarias 7/2017, de 26 de junio: «(...) [P] or las declaraciones claras, precisas y sumamente esclarecedoras prestadas por los testigos antes citados en el acto del Plenario, de las que se desprende que el condenado tenía a la víctima amenazada y vejada, (...), al igual que la intentaba manipular con sus arrepentimientos y la utilización de su hijo para lograrlo, rechazando de plano su mejora laboral y su voluntad de emanciparse económicamente, ejerciendo un control sobre su vida, sus sentimientos y su trabajo, queriendo anular su voluntad de decisión y de respeto sobre sí misma, hasta acabar con su vida, como acto final de dominación» (FJ 4).

187 Por ejemplo, la SAP de A Coruña 213/2017, de 9 de mayo, aun no referiéndose a la intencionalidad de autor, sostiene también un mayor injusto subjetivo del hecho. En concreto, se aclara que se trata de una agravante subjetiva «(...) que adiciona al desvalor propio de la acción el que su motivación predominante radique en una idea de discriminación que tenga por base una característica personal» (FJ 3). Es decir, que el plus de la agravante reside en la negación del principio de igualdad y que, como agravante subjetiva que es, habrá de otorgarse una relevancia preferente al factor motivacional del que aflorará la intención discriminatoria.

188 En esta misma línea se sitúan la mayoría de las sentencias examinadas. En concreto, véanse: STSJ de Canarias 7/2017, de 26 de junio, FJ 4; SAP de Madrid 743/2017, de 1 de diciembre, FJ 7 (más adelante ratificada por STSJ de Madrid 44/2018, de 12 de abril); SAP de Asturias 517/2017, de 4 de diciembre, FJ 3 (ratificada más adelante por la STSJ de Asturias 4/2018, de 2 de marzo); SAP de Madrid 74/2018, de 13 de febrero, FJ 7; SAP de Valencia 147/2018, de 8 de marzo, FJ 3; SAP de Asturias 69/2018, de 9 de marzo, FJ 4; SAP de Madrid 211/2018, de 19 de marzo, FJ 2; SAP de Burgos 179/2018, de 11 de mayo, FJ 7; 
la mayor culpabilidad de autor, a razón de unos móviles especialmente reprochables, abyectos o execrables que impulsan ese actuar y que son contrarios a valores compartidos. La intención del sujeto queda pues relegada al elemento transmisor de ese ánimo discriminatorio que pondría en evidencia que el ataque se produjo sobre la víctima por ser quien era (p.ej.: esposa o compañera sentimental). En modo alguno se busca sancionar creencias o ideas de quien comete el delito, sino más bien que se haya actuado «movido por» tales creencias o ideas. Siendo así, más allá de la mera condición de mujer de la víctima y de su selección con fines delictivos, una exteriorización lo suficientemente precisa de la intención de autor se antoja imprescindible para fundamentar de forma sólida y convincente la agravación de la conducta.

En resumen, desde el primer momento, sea graduando la culpabilidad de autor o graduando el injusto por la vía del mayor desvalor de acción, el factor motivacional o los móviles de autor han ganado interés y han logrado teñir la agravante de un cariz eminentemente subjetivo. La motivación de autor, huelga decir, estará relacionada con la construcción estereotipada y sexista que deriva de la condición de mujer de la víctima ${ }^{189}$. Más allá de la naturaleza subjetiva de la agravante, su estructura también queda definida con un componente objetivo, como es el requisito de que la víctima sea mujer, y otro subjetivo, a saber, el ánimo de autor ${ }^{190}$.

Otras sentencias, en cambio, hablan de la «naturaleza del hecho» (SAP de Lleida 56/2017, de 7 de febrero, FJ 3), que reverbera en la posición de dominio del varón sobre la mujer. Es decir, que los hechos delictivos destilen una clara posición de absoluta superioridad, un clima de dominación y/o una manifiesta situación de desigualdad y relación de poder sobre la mujer. Con todo, también se recuerda que no cabe esquivar el aspecto motivacional de la conducta, debiendo ser objeto de atención preferente junto a la naturaleza —si se quiere, más objetiva— del hecho en sí.

SAP de Valencia 251/2018, de 7 de mayo, FJ 4; SAP de Cantabria 204/2018, de 7 de junio, FJ 5; SAP de Asturias 274/2018, de 12 de junio, FJ 3.

189 Un ejemplo sencillo pero común sobre la estereotipación masculina sobre la mujer puede verse en la SAP de Valladolid 144/2017, de 2 de mayo (FJ 1): «Lo que el acusado hace es aprovechar la labilidad de la víctima para vencer cualquier resistencia, y llevar a cabo las relaciones sexuales de forma violenta, inconsentida, porque espera una conducta sumisa, como al final consigue» (cursiva añadida). Otro ejemplo claro se extrae de la SAP de Segovia 18/2017, de 16 de noviembre (FJ 12): «[E]ste crimen tendría su base psicológica en la negación del acusado a que una mujer, más aún esta mujer, le pudiese abandonar a él, el hombre» (cursiva añadida).

190 Así recogido, entre otras, en: SAP de Madrid 743/2017, de 1 de diciembre, FJ 7 (más adelante ratificada por STSJ de Madrid 44/2018, de 12 de abril); SAP de Madrid 74/2018, de 13 de febrero, FJ 7; SAP de Asturias 69/2018, de 9 de marzo, FJ 4; SAP de Burgos 179/2018, de 11 de mayo, FJ 7. 
Aunque de forma minoritaria, en esta primera etapa aplicativa de la agravante también parecen vislumbrarse destellos de interpretación más objetiva que, no obstante, quedan ampliamente ignorados por la corriente de opinión mayoritaria. Incluso así, la SAP de Cádiz 16/2018, de 19 de enero, acercó sin titubeos el fundamento de la agravante a aquél que inspiró al legislador español a partir de 2004 para introducir ciertos preceptos con marca de género que posteriormente salvaron su constitucionalidad ${ }^{191}$. De esta forma, estaríamos ante unos hechos objetivamente más lesivos en abstracto que la mera lesión al bien jurídico del delito base (en concreto, en este caso, un delito de amenazas y otro de coacciones). El plus de gravedad se situaría en una manifestación específica y especialmente lesiva de violencia cuyo significado objetivo enlaza con una desigualdad arraigada y con una imperecedera relación de poder de hombres sobre mujeres (FJ 6; véase también la STC 59/2008, de 14 de mayo, FJ 9).

\subsubsection{Tribunal Supremo y turbación interpretativa}

La STS 420/2018, de 25 de septiembre (FJ 1), es la primera sentencia en la que el Alto Tribunal entra al fondo del recurso planteado por las partes y estima que concurren los presupuestos o exigencias para su aplicación. En resumidas cuentas, la clave reside en que de los hechos se desprenda un componente de dominación y otro de desprecio en la conducta del acusado ${ }^{192}$. En cuanto al primero, el Tribunal sostiene la exigencia de que la conducta del varón debe ser la expresión de una intención, actitud, o voluntad de establecer o mantener una situación de dominación sobre la mujer. Respecto al desprecio sobre la mujer, se concreta en la intromisión - se entiende, con plenitud de poderes y control- en la toma de decisiones más básicas, personales e íntimas (p.ej.: gestionar su autonomía económica o mantener contacto con amigos o familiares). En este sentido, pareciera como si este segundo componente no fuera sino un centelleo de la intención de dominación que invalida cualquier muestra de libre autodeterminación como mujer. En suma, se perfecciona la grave merma que supone para la víctima verse despojada del respeto más ínfimo a su consideración personal. La intención varonil de control y dominación sobre la mujer reafirma la tendencia jurisprudencial anterior, al menos en lo relativo al cariz eminentemente subjetivo de la agravante. A modo de mera conjetura, parece que es el desvalor

191 En esta misma dirección, aunque más tímidamente, parecía navegar la SAP de Castellón 46/2018, de 12 de febrero (FJ 4). Sin embargo, téngase en cuenta que otras sentencias, aun poniendo en valor este corpus normativo posterior a 2004, acaban por derivar todo el peso del fundamento de la agravante a la mayor culpabilidad de autor por la mayor reprochabilidad del móvil (véase, en este sentido, la SAP de Cantabria 204/2018, de 7 de junio, FJ 5).

192 Así sintetiza esta doctrina la SAP de Palencia 27/2019, de 22 de noviembre (FJ 3). 
de la acción lo que se acentúa a la hora de evaluar la afección al bien jurídico, otorgando una relevancia preferente al factor intencional y la negación de la igualdad de roles.

La STS 565/2018, de 19 de noviembre (FJ 8), confirma de forma expresa que nos hallamos ante un fundamento subjetivo, requiriendo que los actos de machismo y dominación busquen sellar o ratificar un sentimiento de superioridad. Los actos del agresor deben derivar de esa pulsión agresiva que socava la igualdad constitucional. En este caso, en cambio, se nos indica que es el «ánimo» que mueve al autor a mostrar dicha superioridad lo que debe concurrir. Una acción, por tanto, animada por un deseo de preponderancia y hegemonía. Quizás, a falta de un pronunciamiento expreso, ello obligue a sancionar con mayor contundencia el desequilibrio ocasionado respecto a la mayor gravedad de la culpabilidad de autor. En cualquier caso, cabe precisar que el TS ha venido apostando por un entendimiento amplio de la agravante, pudiendo proyectarse también fuera del ámbito relacional de la pareja o expareja ${ }^{193}$. Avanzando ahora hasta la STS 707/2018, de 15 de enero (FJ 6), ella simplemente recoge y descarga toda la fuerza argumental de los pronunciamientos anteriores. En este caso, si bien la acción catalizadora que acabaría concretándose en el asesinato de su mujer lo fue una solicitud de divorcio por parte de esta última, la situación o relación de dominación durante el matrimonio ${ }^{194}$ marcaba el contexto adecuado para una mayor retribución. Se trató de una acción terminante que cobraba sentido a partir del contexto más amplio en el que se insertaba, el cual quedaba debidamente probado.

Este cuerpo de jurisprudencia más o menos compacto y sobresaliente del Alto Tribunal entraría pronto en un estado de catarsis interpretativa. Este punto de inflexión vino originado por la STS 99/2019, de 26 de febrero (FJ 3), que objetivó la doctrina asentada sobre la agravante al tiempo que la acercaba a la instaurada de un tiempo a esta parte para el delito de maltrato ocasional (art. 153.1 CP). El resultado más importante es que de la situación de dominación contextual no cabe exigir lo que tampoco emana de la normativa penal; esto es, no se demanda ningún elemento subjetivo del injusto superpuesto al genérico del dolo. No se exige, por tanto, acudir en sede probatoria a verificar una voluntad, in-

193 En la STS 420/2018, de 25 de septiembre (FJ 1), se indica que la agravante de desprecio de género amplía la protección con carácter general, no ciñéndose esta circunstancia a los tipos con marca de género de la parte especial. La STS 565/2018, de 19 de noviembre (FJ 8), es si cabe más contundente al afirmar que no hace falta que exista o haya existido vínculo de afectividad, sino que lo determinante es que la víctima lo sea «esencial y únicamente por ser mujer».

194 Tal situación de dominación encontraba su correlato fáctico en los siguientes aspectos que se detallan: «Durante el matrimonio el encausado había impuesto sus condiciones, en el estilo de vida de la pareja, haciendo prevalecer sus decisiones en todos los temas importantes, alejándola y aislándola paulatinamente de su familia y su entorno» (FJ 6). 
tención o propósito de dominación por parte del varón sobre la mujer ${ }^{195}$. Aun así, no es menos cierto que para apreciar la agravante siempre deberá probarse caso por caso la situación de dominación o la asimetría entre varón-agresor y mujer-víctima ${ }^{196}$, sin que quepa en modo alguno avanzar presunciones aplicativas como ocurre en otros delitos con marca de género y como sería el caso del art. $153 \mathrm{CP}^{197}$. Dicho lo anterior, y al hilo de la conocida doctrina que rodea al artículo recién referido, el Tribunal recuerda que es la fuerza de los hechos y su especial lesividad objetiva cuando el ámbito relacional se inmiscuye de por medio lo que determina su significación especial. No es el sexo de los sujetos, sino unos hechos que enlazan con pautas culturales de discriminación y opresión. Hechos, además, que se retroalimentan los unos a los otros siendo causa y expresión de dicha situación de desigualdad vigente.

El problema con el que se topó el Alto Tribunal y al quiso darle salida fue el de tener que trasladar a la agravante por motivos discriminatorios de género todo este trasfondo jurídico. En efecto, la encrucijada consistía en que el tratamiento más favorable a la mujer (medidas de acción positiva), no por su sexo, sino por radicar dentro de un tipo de criminalidad real, flagrante y objetiva, se sostenía única y exclusivamente en la medida en que existiera un ámbito relacional entre las partes involucradas (varón-mujer). Si la agravante por motivos discriminatorios de género aspiraba a rebosar dichos límites, es decir, a hacerla extensible a todo tipo de violencia sin sustento en lazos afectivos ni conyugales, desde luego el fundamento y su razón de ser renquearían ostensiblemente. A tal fin, con miras a su corrección, se dispuso cuanto sigue: «La interpreta-

195 Sobre este particular, véase también la STSJ de Castilla y León 53/2019, de 27 de septiembre: «No se trata de tener que probar específicamente que el acusado actuó por el móvil o con la intención de imponer su voluntad y dominación sobre la esposa, pues como sabemos los ánimos o intenciones quedan dentro del espacio cerrado de la mente humana, pero que ello fue así se deduce claramente de las circunstancias previas a la comisión del hecho perfectamente reflejadas en la sentencia recurrida» (FJ 4).

196 A modo ilustrativo, la STS 420/2018, de 25 de septiembre, sostiene que los elementos fácticos en los que se apoye la concurrencia de la agravante «(...) deben aparecer nítidamente en los hechos probados y, para ello, han de estar debidamente acreditados por prueba válida, suficiente y racional y expresamente valorada en la sentencia» (FJ 1). Los presupuestos fácticos de la agravación deben estar probados en igual medida y consideración a los del hecho delictivo que se agrava. Según SANZ Mulas, el componente de discriminación es connatural al concepto mismo de violencia de género, por lo que en los delitos con marca de género no se precisa demostrar tal aspecto, como sí que ocurrirá en los delitos neutros (o sin marca de género) a los que se trate de agravar la pena vía art. 22.4 CP. Véase Sanz Mulas, N., Violencia de género...op. cit., p. 96.

197 Así, según la SAP de Madrid 184/2020, de 12 de marzo, el Tribunal Supremo simplemente «matiza» su línea de entendimiento al relativizar el propósito de autor y «otorgar un carácter cuasi objetivo a la agravante» (FJ 2; cursiva añadida). Quizás, más que «matizar», el Tribunal Supremo da «un giro de tuerca más» (SAP de Palencia 27/2019, de 22 de noviembre, FJ 3), teniendo como resultado una «importante inflexión en la lectura de la agravante de género» al «debilitar notoriamente el elemento subjetivo» (STSJ de Madrid 77/2020, de 28 de febrero, FJ 9). 
ción de la previsión legal ha de enmarcarse en un objetivo corrector de la desigualdad o discriminación, ocurrida en un ámbito de relación autorvíctima, más específico que la diversidad de sexo biológico y más amplio que el del parentesco conyugal, y en el que aquella relación suponga un estatuto social, antes que jurídico, del que deriva una discriminación para la mujer relacionada socialmente con el autor del delito. (...) Para aplicar la agravante en casos ajenos a esa relación de pareja habrá de exigirse al menos una asimetría en la relación entre varón-autor y mujer-víctima que sea reflejo de la discriminación que constituye el fundamento de la mayor sanción penal» (FJ 3; cursiva añadida).

La fundamentación, por tanto, parece bicéfala. Se entiende que, al exponer que en los casos ajenos a tal relación de pareja la clave reside en la asimetría de sexos (situación de desigualdad) producto de la discriminación secular contra dicho colectivo, el fundamento para cuando existe o ha existido de facto dicha relación se aproximará entonces al cuerpo doctrinal construido alrededor del art. $153 \mathrm{CP}^{198}$. En suma, se trataba de parchear allí donde el argumento que actuaba de sostén hacía aguas. Es decir, el elemento objetivador que ponía el acento en la mayor fuerza de los hechos no era válido al extrapolarse a otras realidades, por lo que el Tribunal se zafa del peso que supondría mantener tal argumentación y ahondar en contradicciones con su propia doctrina. En definitiva, al menos en atención al caso que le ocupaba entonces, el Tribunal entiende que será suficiente con probar, en lo referente al plano subjetivo, la consciencia de la relación que une a víctima y agresor ${ }^{199}$, así como a la voluntad de cometer el delito base correspondiente.

En cuanto a aquellos casos en que no exista tal vínculo de pareja o expareja, ante la falta de mayor concreción práctica por parte del Tribunal, MAGRO SERVET alude al componente de dominación y subyugación del varón sobre la mujer bajo la idea de «poner un candado». Es, en suma, la forma de decirle a la víctima — en el momento mismo en que se produce la agresión - que pasa a ser propiedad ajena y que queda

198 Por poner un ejemplo, alrededor de dos meses antes, el Tribunal Supremo aludía a las «especiales condiciones y/o circunstancias» de ciertos tipos con marca de género que, en su comisión, dejaban al descubierto el «contexto sociológico de desequilibrio en las relaciones». Siendo así además que actuaría una presunción iuris tantum en la apreciación de dicho componente, debiendo ser el acusado el que desvirtúe tal presunción demostrando que no se trataba de un acto "de género» sino que obedecía a otros parámetros bien diferentes (STS 677/2018, de 20 de diciembre, FJ 3).

199 En términos generales, entonces, y sin que la víctima esté necesariamente relacionada con el agresor varón, ALONSO ÁLAMo habla acertadamente de que exista «una especie de conocimiento latente» por parte de este último sobre la situación de desigualdad y discriminación. Véase Alonso Álamo, M., «El delito de feminicidio. Razones de género y técnica legislativa», en Monge Fernández, A. (dir.)/Parrilla Vergara, J. (coord.), Mujer y derecho penal. ¿Necesidad de una reforma desde una perspectiva de género?, Bosch, Barcelona, 2019, pp. 114-115. 
sometida a su voluntad ${ }^{200}$. Pero yendo más allá, cabe apuntar que es la irremediable subordinación a la voluntad de su agresor, quedando entonces la víctima desprovista de libre autodeterminación, la que permite hablar de un desequilibrio de fuerzas (es decir, la asimetría de sexos que reflejaba ya la STS 99/2019, de 26 de febrero [FJ 3]). Así lo entiende la SAP de Madrid 124/2020, de 14 de febrero, con el matiz aclaratorio de que es la «diversa correlación de fuerzas» y un actuar conforme a ella lo que serviría de fundamento a la agravante dentro o fuera del ámbito relacional (FJ 7). Ello no está en contradicción con las diferentes vías de fundamentación (fundamentación bicéfala, como ya nos habíamos referido antes al comentar la STS 99/2019, de 26 de febrero [FJ 3]), dependiendo de si la víctima era o no una persona con lazos afectivos presentes o pasados con su agresor. De hecho, el Tribunal Supremo hablaba de que fuera de esos lazos habría de «exigirse al menos» la asimetría de sexos (STS 99/2019, de 26 de febrero [FJ 3]). Por todo ello, queda ya claro que la agravante por motivos discriminatorios de género del art. 22.4 CP mantiene cuando menos este suelo común, sin importar que la agresión se haya cometido dentro del marco de una relación afectiva (actual o pasada) o en circunstancias en que no existan $-\mathrm{y}$ no hayan existido nunca- tales vínculos afectivos.

No obstante todo lo anterior, la STS 351/2019, de 9 de julio (FJ 3), volvería a insistir en que la agravante por motivos discriminatorios de género es de aplicación cuando se cometen los hechos contra la mujer, por ser mujer, y con la intención de reafirmar el sentimiento de superioridad del agresor varón. Asimismo, el Tribunal Supremo parece referirse a la intención como forma de vehiculizar y acreditar la motivación subyacente de autor. En esta dirección navegan también la STS 12/2020, de 23 de enero (FJ 2), la STS 136/2020, de 8 de mayo (FJ 3) y la STS $257 / 2020$, de 28 de mayo (FJ 6), que citando la jurisprudencia anterior a la interpretación más objetiva fijada por la STS 99/2019, de 26 de febrero, vuelven a reincidir en la fundamentación subjetiva de la agravante y en el ánimo de mostrar su superioridad sobre la mujer, considerándola inferior sólo por el hecho de serlo. El ánimo de autor deberá concurrir, siendo los actos violentos los que mejor evocan esa intención de dominación ${ }^{201}$. Una intención, se entiende, que canaliza hacia el ex-

200 Véase: MAgro Servet, V., Manual práctico sobre agravantes y subtipos agravados en el Código penal, La Ley, Madrid, 2019, p. 120; MAGRo SERVET, V., Guía práctica penal de delitos de violencia de género, La Ley, Madrid, 2020, p. 206.

201 La STS 351/2019, de 9 de julio (FJ 3), recoge bien esta misma idea: «En el fondo la agresión supone un mensaje de dominación intrínseca que no se expone externamente con palabras, pero sí con el gesto psicológico que lleva consigo el golpe, o el mal trato como aviso a la víctima de las consecuencias de su negativa a aceptar el rol de esa dominación» (resaltado añadido). Este extracto ha sido reproducido en diferentes ocasiones: STSJ de Madrid 195/2019, de 2 de octubre (FJ 7); SAP de Lleida 482/2019, de 19 de diciembre (FJ 5); SAP de Sta. Cruz de Tenerife 42/2020, de 14 de febrero (FJ 5); SAP de Madrid 151/2020, de 2 de marzo (FJ 3). 
terior dicho ánimo y lo patentiza. Entre otros supuestos que evidencian el fin de autor de sentirse superior a través de unos actos, encontramos las reacciones violentas y posesivas por parte del varón sobre la mujer (p.ej.: no aceptación de la ruptura de pareja) o la cosificación misma de la mujer sin reparar en el igual valor que su dignidad merece. En cualquier caso, queda claro que la relación varón-mujer debe asentarse en el trato desigual por razón de sexo, sin importar que se extravase el ámbito relacional de los involucrados. De hecho, para este último supuesto en concreto, la STS 257/2020, de 28 de mayo (FJ 6), indica que la agravante por motivos discriminatorios de género del art. $22.4 \mathrm{CP}$ podrá aplicarse «aisladamente», lo que ocurrirá cuando se pruebe que la infracción penal se cometió mediando actos que impliquen dominación del hombre hacia la mujer simplemente por serlo.

\subsubsection{Reflexiones y posicionamiento}

El seguimiento realizado a la fundamentación de la agravante por motivos discriminatorios de género facilita la imagen jurisprudencial de una apuesta por la aproximación subjetiva (culpabilística) de autor a la hora de situar el mayor desvalor penal. Esta es la corriente de opinión jurisprudencial mayoritaria también para el resto de categorías protegidas por el art. 22.4 $\mathrm{CP}^{202}$, requiriéndose llegar a acreditar el ánimo reprochable de autor. Además, la jurisprudencia ha sido clara al señalar que el motivo discriminatorio debe ser el desencadenante de la infracción penal, por lo que su concurrencia vendrá determinada siempre por el momento anterior al dolo. Ello supone que ciertas expresiones objetables y marcadamente prejuiciosas tengan un papel jurídico diferente en función del momento en que se expresen: (i) si se exteriorizan inmediatamente antes de la comisión delictiva, se consideran elementos indiciarios para probar el ánimo de autor; (ii) si se exteriorizan al tiempo o después de cometer la infracción penal, no motivan el hecho delictivo y son incluso canalizables a otros tipos penales (p.ej.: las injurias) ${ }^{203}$.

Con todo, alguna voz doctrinal venía sugiriendo que es la formulación misma de la agravante por motivos discriminatorios la que propiciaría una aproximación dispar en función de la categoría protegida.

202 Sobre la discusión doctrinal y el estado general de la jurisprudencia en torno al art. 22.4 CP, véase LaNDA Gorostiza, J.M., Los delitos de odio...op. cit., pp. 121-135.

203 Así lo recogen: SANTANA VEGA, D.M., «El tratamiento penal de la discriminación por razón de orientación o identidad sexuales», en CUESTA LóPEZ, V./SANTANA VEGA, D.M. (dirs.), Estado de Derecho y discriminación por razón de género, orientación e identidad sexual, Aranzadi/Universidad de las Palmas de Gran Canaria, Cizur Menor/Las Palmas de Gran Canaria, 2014, p. 397; Presno Linera, M.A., «El discurso del odio contra las minorías sexuales: respuestas penales y administrativas», en MATIA PorTiLLA, F.J./ElviRA Perales, A./Arroyo Git, A. (dirs.), La protección de los derechos fundamentales de personas LGTBI, Tirant lo Blanch, Valencia, 2019, p. 298. 
Las cláusulas «motivos racistas y antisemitas» y «otra clase de discriminación referente a (...) [entre otras, las] razones de género» no admiten equiparación en su tratamiento legal (interpretación forzada de la ley respecto al art. 22.4 CP). Este es el caso de Alonso Álamo, quien tiempo atrás ya había señalado que tal planteamiento evidenciaba la naturaleza objetivo-subjetiva de la agravante, siendo la segunda de las fórmulas la que podía entenderse como una apuesta por la objetivización (parcial) de la agravante sita en el art. 22.4 $\mathrm{CP}^{204}$. De hecho, esta segunda fórmula resulta ser la única que involucra actualmente a las razones de género. Por tanto, concuerdo con la propuesta correctora de lege lata que expone Alonso Álamo, entendiendo que las «razones de género» invitan a mantenernos en los dominios del examen de los indicadores externos de los hechos; y que, por consiguiente, nuestro análisis debe pivotar en torno al mayor contenido del injusto modulando en este caso el desvalor de resultado. Es decir, que basta con un dolo típico y con el conocimiento de que la conducta, tal como se haya manifestado, resulte de sometimiento objetivo, mediando un ejercicio del dominio del varón sobre la mujer y el trato desigual ${ }^{205}$.

A pesar de lo expuesto, Alonso Álamo critica abiertamente que puedan existir, en términos generales, agravantes o tipos agravados que descansen sobre el ánimo de autor. De hecho, terminología como «menosprecio» o «desprecio» de la víctima nos retrotraen a ese papel importante que puedan jugar ciertas emociones ${ }^{206}$. Sin embargo, al menos desde estándares normativos, entiende HÖRNLE que debe ser posible atemperar las presunciones subjetivistas que tienden a trascender al hablar, por ejemplo, de términos como el de «humillación». A fin de rebajar tales automatismos que conducen a la ruta incierta de adentrarnos en el interior de un individuo, sea víctima o agresor, la autora cree que es posible implantar estándares estrictamente objetivos. La importancia de las relaciones e interacciones humanas en un mundo simbólico, no sólo físico, y el hecho de que existan suficientes consensos sociales en un contexto de respeto mutuo bajo unos mismos cánones culturales, deben permitir deshacernos de las ataduras psicológicas de cierto uso legal del lenguaje. Un ejemplo que expone HOORNLE son las graves y salvajes agresiones sexuales, o las diatribas racistas en que las

204 Alonso Álamo, M., «La circunstancia agravante de discriminación», en DíEz RiPoLLÉs, J.L. (coord.), La ciencia del derecho penal ante el nuevo siglo: libro homenaje al profesor doctor don José Cerezo Mir, Tecnos, Madrid, 2002, p. 537.

205 Alonso Álamo, M., «El delito de feminicidio...op. cit., pp. 111-112.

206 Según reconoce, vislumbrar elementos subjetivos del injusto, incluso basados en motivos de autor, puede en ocasiones servir para limitar intromisiones penales más amplias con arreglo a la ley. No obstante, esto último sería poco aceptable de referirnos a la práctica consistente en agravar la responsabilidad penal mediante agravante genérica o tipos cualificados. Y ello es así porque se abre la veda a un "alto grado de inseguridad» propia de los procesos motivacionales. Véase Alonso Álamo, M., «El delito de feminicidio...», op. cit., pp. 120-121. 
minorías son catalogadas como infrahumanas y objeto de exterminio. A partir de estos y otros ejemplos, ciertas caracterizaciones pueden extraerse e ir conformando clasificaciones más generales. Por ejemplo, prosigue la autora, la demostración de falta de respeto (demonstration of disrespect) o las situaciones en las que la víctima es colocada en una posición de completa indefensión o desamparo (situations in which the victim is made entirely powerless and totally helpless) pueden, sin más añadidos, elevar una conducta a la categoría de humillación grave ${ }^{207}$.

Por consiguiente, si bien Alonso Álamo recelaba del empleo de terminología muy escorada hacia postulados subjetivistas, entiendo que existen otras corrientes de pensamiento en pos de no alterar una jerga legal ya absorbida con el paso del tiempo (véase, sin ir más lejos, cómo la jurisprudencia sobre la agravante por motivos discriminatorios de género incide recurrentemente en el componente de «desprecio» a la mujer). Lo mejor que podría hacerse es darnos a nosotros mismos unas reglas objetivas, consensuadas y pacíficas de juego para que la función agravatoria de la pena deje tras su aplicación puntos de retorno judicial firmes y seguros. En un intento de fijar parámetros claros sobre hechos que presupongan en abstracto ${ }^{208}$ un acto de dominación y de sometimiento a la víctima del sexo contrario, un ejemplo bien podría ser el siguiente: marido que al llegar a casa y no encontrar la cena hecha o caliente propina una bofetada gratuita a la mujer sin mediar palabra, ya que ella iba a comprender perfectamente que esa reacción tenía el significado preciso que él quería dar a entender.

La deficiente formulación del art. $22.4 \mathrm{CP}$, ya sea por entenderse bifronte (objetivo-subjetivo) o por reforzar la caracterización subjetiva de la agravante in totum mediante el empleo de términos abiertamente subjetivos (esto es, «motivos») en su redacción, no impide —sino que sólo dificulta- una interpretación que anteponga los efectos sobre el sujeto pasivo a la actitud anímica ${ }^{209}$. Por tanto, entiendo, sería

207 En detalle, véase HörnLE, T., «How to define human dignity, and the resulting implications for biotechnology», en Grimm, D./Kemmerer, A./MöLlers, C. (eds.), Human dignity in context. Explorations of a contested concept, Nomos, Baden-Baden, 2018, pp. 573-576.

208 Es importante incidir en que la valoración de los hechos debe serlo en abstracto, ya que como se verá en breve siempre existirán elementos de contexto, personales y de acción que reafirmarán o harán decaer esta consideración prima facie y más genérica.

209 En detalle, nos remitimos en este punto a LAURENZo COPELLO, quien aparte de explicar dicha posibilidad estima que la ley debió referirse a "cometer el delito contra determinadas personas por razón de su ideología, etc.». Con todo, insiste, que esto no haya sido así no cierra las puertas a entendimientos que pongan el acento en el carácter objetivo de la circunstancia agravante en su conjunto. LAURENZo Copello, P., «La discriminación en el Código penal de 1995», Estudios penales y criminológicos, Núm. 19, 1996, p. 281. Sumándose a esta corriente interpretativa, si bien añadiendo la trascendencia colectiva del acto que debiere siempre activar este castigo agravado, véase LANDA GoRosTIZA, J.M., Los delitos de odio...op. cit., pp. 125-126.Véase también una referencia a todo lo anterior en: 
recomendable —además de posible - reconducir la agravante en su conjunto a una deriva que objetive el fenómeno de la criminalidad por odio. De hecho, este primer encuentro normativo entre el género, entendido conforme al Convenio de Estambul, y los delitos de odio, debería servir como palanca de cambio para que se abra sin miedo la senda de la objetivación de unos hechos que, por su propia idiosincrasia, merecen en abstracto ese mayor desvalor.

En definitiva, como ya mencionábamos en otro lugar, interesa corroborar un contexto en el que el autor simplemente no sea completamente ajeno al impacto de sus actos sobre el colectivo mujer. Nos guiamos así por una conducta, quizás ni tan siquiera intencional en cuanto a sus consecuencias, pero que desemboca en unos hechos perceptibles como el vivo reclamo de dominación y sometimiento de la mujer por el mero hecho de serlo. No se trata de determinar qué es lo que movió su actuar de la forma en que lo hizo, sino de que el efecto socialmente dañino que se proyecta sobre la mujer $-\mathrm{y}$, persona interpuesta mediante, con afección intimidante supraindividual-conserve lazos con patrones culturales trasnochados que no escapaban a su conocimiento, sea o no su voluntad.

De esta forma, la prueba no debería desatender la impronta del momento (sea inmediatamente antes, durante o después del comportamiento delictivo), evitando eso sí, como es común en la práctica judicial, un viaje al pasado ad infinitum. Se deben estrechar, con buen tino pero también con cintura valorativa respecto al caso concreto, los tiempos que marca el propio acto al desnudo (p.ej.: dejar constancia de comentarios, actitudes o comportamientos sexistas que preceden o siguen al acto). Todo lo demás coloreará la valoración global de lo ocurrido, relativizando o remarcando la crudeza de los hechos. Por ejemplo, la STSJ de Madrid 77/2020, de 28 de febrero (FJ 9), entiende que se deben valorar conjuntamente elementos de contexto, personales y de acción. De esta forma, tienen cabida y complementan los hechos formulados en abstracto aspectos tales como: (i) una relación intermitente (y con problemas) o duradera (y pacífica) entre ambos; (ii) el hecho de haber convivido, no haberlo hecho o estar haciéndolo; (iii) los móviles del delito; (iv) el mo-

AsUa BATARRITA, A., "Ni impunidad ni punitivismo. Sinrazones de la actual interpretación de la agravante por razón de género del artículo 22.4 del Código Penal», en OtAZUA ZaBALA, G./GutiéRreZ-SOlana Journoud, A. (dirs.), Justicia en clave feminista. Reflexiones en torno a la inserción de la perspectiva de género en el ámbito judicial, Universidad del País Vasco (UPV/EHU), Bilbao, 2021, pp. 172-173; AsUa BATARriTA, A., «La razón de género...op. cit., p. 371.

En esta línea, la propia Alonso Álamo propone de lege ferenda que se altere la redacción del art. 22.4 CP en el sentido de prescindir de la alusión a «motivos». Asimismo, concuerda también con el hecho de que la reciente vinculación del género con los delitos de odio confiere una dimensión supraindividual a las agresiones delictivas. Alonso Álamo, M., «El delito de feminicidio...»op. cit., pp. 116, 118 y 120. 
mento y lugar en que ocurren los hechos; etc. Son elementos, entiendo, que no tienen el carácter de definitivos a efectos de apreciar la agravante, pero que sin duda imprimen una mayor o menor credibilidad al desvalor que merecen los hechos. En cualquier caso, conviene insistir en que valoraciones decidida y abiertamente diacrónicas no deben prosperar, por cuanto así se limita también la peligrosa tendencia a empañar el carácter objetivo de los hechos.

\section{Conclusiones}

Una mirada detenida a los datos que devuelve el examen jurisprudencial sobre condenas (y confirmaciones de condena) en torno a la agravante del art. 22.4 CP pone de manifiesto varios aspectos de interés. En primer lugar, el uso absolutamente recurrente de la agravante por motivos discriminatorios de género hace que despunte respecto al resto de categorías protegidas en términos aplicativos. Esto no sucede en el vacío, sino en el contexto de la incorporación tardía del género a la agravante en 2015 y de la mesura aplicativa por parte de nuestros jueces y tribunales respecto al resto de categorías. Parece evidente, pues, que el género ha estimulado la aplicación de un instrumento excepcional ${ }^{210}$ de tutela. El colectivo mujer, alejado en clave numérica del resto de categorías protegidas, se consagra como colectivo que puede ser victimizado por considerarse amenazante para el statu quo, o simplemente frágil -incluso, hasta el extremo de lo irrelevante- en términos de poder en diferentes ámbitos de nuestra vida en sociedad. No obstante, esta praxis judicial expansiva española contrasta con la estadounidense o la australiana, más reservadas y timoratas a la hora de generalizar la aplicabilidad de la agravante por motivos discriminatorios de género.

En segundo lugar, se confirma la tendencia que ya venía sugiriéndose $^{211}$ acerca de una aplicación más generalizada de la agravante por motivos discriminatorios de género (art. 22.4 CP) en aquellos delitos más graves. En concreto, en los delitos de asesinato y homicidio (delitos de sangre). Sin embargo, pese a que en teoría se ha

210 Una nota de excepcionalidad de la que también depende, en cierta medida, cualquier circunstancia modificativa de la responsabilidad penal. En concreto, respecto a la agravante por motivos discriminatorios de género, la STSJ de Madrid 77/2020, de 28 de febrero, es clara cuando advierte de que no puede deducirse una aplicación automática de la misma en delitos cometidos contra una víctima mujer, y ello a pesar de que su ámbito de aplicación se haya ampliado considerablemente. De esta forma, la agravante «(...) ha de fundamentarse en una base perceptible, no indiscriminada, pues entonces dejaría de ser una circunstancia modificativa de la dimensión de la pena que el delito lleva aparejada por sí mismo para convertirse en un elemento más del tipo, a modo de un subtipo agravado natural siempre que la víctima fuese mujer» (FJ 9).

211 CGPJ, Análisis de la aplicación...op. cit., p. 17 
extendido su uso a casos que quedan fuera de los círculos afectivos, no deja de sorprender lo imperceptible de su traslación práctica ${ }^{212}$. Más aún cuando, en derecho comparado, el sentido aplicativo de la agravante busca situarse dentro de esta casuística concreta de victimización. En cualquier caso, queda claro que los jueces y tribunales españoles se han mostrado especialmente proclives a la apreciación de la agravante en casos que involucran vínculos afectivos muy concretos. Esto es, la víctima como (ex)pareja o (ex)esposa ${ }^{213}$, lo sea directa o indirectamente ${ }^{214}$. En consonancia con lo anterior, el domicilio sigue siendo el lugar donde indiscutiblemente se cometen la gran mayoría $-\mathrm{y}$, en concreto, más de la mitad del total— de delitos agravados por las razones de género del art. $22.4 \mathrm{CP}$.

Estos apuntes reflejan lo que tiene visos de ser toda una evidencia, y es que la jurisprudencia sigue encasillada en el concepto de violencia de género propuesto por la LO 1/2004. Como es sabido, esta ley conceptúa de forma restrictiva la violencia de género ${ }^{215}$, siendo así que sus formas de manifestarse no escapan del marco de la relación conyugal o

212 Que se tenga constancia, una única sentencia — dictada por conformidad — agrava la pena a un agresor por razones de género sin que exista ningún vínculo o relación previa entre víctima-agresor (SAP de Barcelona 275/2019, de 2 de mayo).

213 En detalle, para conocer algunas posiciones críticas acerca de la naturaleza no fungible de la víctima en casos de violencia contra la (ex)pareja o (ex)esposa, lo que haría potencialmente insostenible la dimensión supraindividual y/o el mensaje intimidante que se proyecta ad extra en los delitos de odio como pauta comunicativa, véase: AsUA BATARRITA, A., «Ni impunidad...», op. cit., pp. 174-175; La misma, «La razón de género...», op. cit., pp. 371-372; Pérez Manzano, M., «En busca de la identidad del feminicidio de la pareja o expareja: entre el odio y la discriminación», $A D P C P$, Vol. 71, 2018, pp. 102-105; DoPIco GómEZ-Aller, J., «Delitos cometidos por motivos discriminatorios: una aproximación desde los criterios de legitimación de la pena», $R G D P$, Núm. 4, 2005, pp. 32-33.

214 Por ejemplo, el supuesto de que el autor cometa el hecho delictivo sobre alguno de los descendientes de la mujer. El entendimiento de este tipo de violencia que instrumentaliza a los hijos (y que revela también aspiraciones de control y dominio) como posible supuesto violencia de género se venía sosteniendo por LARRAURI PIJOAN, E., Criminología crítica...op. cit., p. 49.

A este respecto cabe mencionar la SAP de A Coruña 484/2018, de 16 de octubre, única de entre todas las examinadas que aprecia la agravante dentro de esta lógica. En concreto, se recoge que «(...) el Jurado estimó probado por unanimidad que el acusado ejecutó la muerte de su hijo por razones de dominación y desprecio sobre la mujer, en concreto sobre la que había sido su esposa» (FJ 7). Refiriéndose a las pruebas que sostienen tal veredicto, de ellas «se desprende una específica motivación del acusado, que no aceptó la ruptura de la relación y que reaccionó causando la muerte de su hijo para dañar de la forma más cruel que estaba a su alcance a su ex mujer y precisamente un día tan significativo [Día de la Madre]». Esta sentencia sería confirmada primero por la STSJ de Galicia 14/2019, de 31 de enero, y acto seguido por la STS 339/2019, de 3 de julio.

215 Para una síntesis evolutiva del concepto, criticando diferentes aspectos relacionados con su formulación o comprensión a lo largo de los años, véase TAMARIT SuMALLA, J.M., «¿Cuándo la violencia es de género?: ley, ciencia y política en la jurisprudencia», en TAmarit Sumalla, J.M./Pereda Beltran, N. (coords.), Violencia de género en las relaciones de pareja, Marcial Pons, Madrid, 2020, pp. 21-26. 
análoga de afectividad, aun sin convivencia, presente o pasada. A pesar de que nuestros jueces y tribunales reconocen que el género incorporado a la circunstancia agravante del art. 22.4 CP rebasa dicho marco, acompañando tales afirmaciones con referencias constantes al Convenio de Estambul, este estudio revela cierta continuidad de criterio. Al parecer, la jurisprudencia ha quedado atrapada en una forma de entender la violencia de género ciertamente limitada ${ }^{216}$ y muy desacompasada respecto a los estándares internacionales sobre la materia. El hecho de que ahora un volumen importante de los delitos agravados por las razones de género incorporadas al art. 22.4 CP hayan tenido lugar en un domicilio, no parece en absoluto algo casual. A su vez, aunque se progresa en valorar el género en los delitos contra la libertad sexual $^{217}$ o contra la vida, entre otros, no se ha logrado avanzar en hacer esa protección extensible al resto de mujeres con las que no se mantenga o se haya mantenido una relación de afectividad. La definición más amplia y completa sobre violencia basada en el género que dispusiera en su día el Convenio de Estambul, por el momento, se acaba diluyendo

216 Por si fuera poco, ahora se superponen formas contrapuestas de entender el componente de género sin salir siquiera de ese concepto tan acotado de violencia de género. En opinión de CARRERAS PRESENCIO, es hora de que el legislador español afronte no ya una simple modificación, sino una verdadera transformación del concepto jurídico de violencia de género. En concreto, este proceso se inició de la mano de la reciente incorporación del género en la circunstancia agravante genérica del art. 22.4 CP. Con todo, si bien soplaban vientos de cambio, esta autora considera que se ha fracasado al tratar de trasladar todo cuanto se había construido alrededor del ámbito de las relaciones de pareja o expareja (violencia de género en sentido limitado, según la LO 1/2004) a un escenario en que puede ya superarse ese ámbito relacional (violencia de género en sentido amplio, según deriva del art. 22.4 CP). La agravante del art. $22.4 \mathrm{CP}$, influida por la corriente de opinión mayoritaria en torno al resto de categorías protegidas, toma distancia y se asienta sobre claves de entendimiento e interpretación muy diferentes a las que arrastran los tipos penales con marca de género. Por ello, la autora constata que esas claves de interpretación más objetivas de los tipos penales con marca de género se pierden cuando el agresor hombre actúa dentro del ámbito relacional de quien ha sido su pareja o expareja pero llevando a cabo una conducta que se incardina fuera de los tipos penales con marca de género. En definitiva, unos mismos hechos, dependiendo de su tipificación penal, son merecedores de interpretaciones «antagónicas» para apreciar la perspectiva de género. En detalle, criticando lo anterior a la vez que se denuncia la falta de voluntad que ha existido para superar el concepto limitado de violencia de género previsto por la LO 1/2004, e imposibilitando así que se siguiera el compás que marca su tratamiento jurídico internacional, véase CARreras Presencio, A.I., Concepto jurídico de violencia de género, Dykinson, Madrid, 2019, pp. 117-137.

217 Así lo entiende también Vidales Rodríguez. En sentido distinto, Asua Batarrita alerta de que la jurisprudencia habría abierto la caja de pandora respecto a la aplicación - a la larga incontrolable- de la agravante por motivos discriminatorios de género del art. 22.4 CP a los delitos contra la libertad sexual, siendo a su juicio improcedente debido a la inherencia del desvalor de la agravante en esta tipología de delitos tan heterogénea. Véase: Vidales RodRíguez, C., «La generalización del género: reflexiones en torno a la agravante de discriminación por razón de género", Revista General de Derecho Penal, Núm. 32, 2019, pp. 12-13; Asua Batarrita, A., «Ni impunidad...», op. cit., pp. 182-183; Asua BatARrita, A., «La razón de género...», op. cit., p. 375. 
en un mero reconocimiento formal en sede judicial. En este punto, en tanto no se acometa una revaluación sistemática sobre lo disfuncional que resulta el hecho de que convivan los delitos con marca de género y la agravante genérica que nos ocupa, no puede dejar de insistirse en una aplicabilidad de la variable de género dentro del art. 22.4 que supere los contornos conceptuales que quedaron fijados por la LO 1/2004. Cualquier otra alternativa ${ }^{218}$, según LlORIA GARCíA, no sólo supone nadar a contracorriente de los compromisos internacionales, sino que entorpece la posibilidad de romper con la concepción de la violencia contra la mujer como una "subclase de violencia familiar» 219 .

Finalmente, es cuando menos curioso que, situándose nuestros tribunales a cobijo de la opción de tratar de acreditar el ánimo de autor que le impulsa a delinquir sobre la mujer, existan tantas resoluciones condenatorias con aplicación de la agravante por motivos discriminatorios de género cuando, a su vez, esta es la corriente mayoritaria también para el resto de categorías protegidas por el art. $22.4 \mathrm{CP}$ y ello no sucede así (número de condenas muy discreto). Si bien la doctrina seguirá expectante en torno a la eventual consolidación de tal vía interpretativa, nos podemos preguntar ya si, quizás de forma poco reflexiva, nuestros tribunales simplemente han abrazado las pautas interpretativas dominantes en la agravante por motivos discriminatorios del art. 22.4 CP y se han encontrado ellos mismos con unos resultados totalmente inesperados.

218 Aunque no ha sido objeto de atención preferente en este estudio, MARÍn DE ESPINOSA CEBALlos propuso explorar otra vía, a modo de propuesta de lege lata, como era la de valernos de la agravante genérica por razón de sexo (art. 22.4 CP) para los casos de violencia de género ejercida fuera del ámbito privado. Ahora bien, resulta fundamental entender que esta autora parte de que la discriminación por el sexo ya abarca propiamente la discriminación por razón de género, al ser conceptos indisociables (el sexo como el "género» y el género como la «especie»). Si se quiere, según diferentes autores y en palabras de Rueda Martín, «la violencia de género es una violencia sexista». Pero siguiendo ya con la propuesta que avanzábamos, la agravante genérica por razón de género (art. 22.4 CP) se seguiría ocupando del mismo ámbito relacional que aquél previsto para la LO 1/2004, si bien alcanzando a todas aquellas conductas que no fueran ya de por sí subsumibles en alguno de los tipos penales con marca de género (p.ej.: atentados a la vida, a la libertad sexual y a la integridad física y psíquica de mayor entidad). En detalle, véase: MARín DE EsPinosa CEBALlos, E.B., «La agravante genérica de discriminación por razones de género (art. 22.4 CP)», en Morales Prats, F./Tamarit Sumalla, J.M./García Albero, R. (coords.), Represión penal y Estado de derecho. Homenaje al Profesor Gonzalo Quintero Olivares, Aranzadi, Pamplona, 2018, p. 424; Marín De EsPinosa Ceballos, E.B., «La agravante genérica de discriminación por razones de género (art. 22.4 CP)», RECPC, Núm. 20, 2018, pp. 18-19; RUEDA MARTín, M.A., La violencia sobre la mujer en su relación de pareja con un hombre. Análisis doctrinal y jurisprudencial, Reus, Madrid, 2012, pp. 51-52; RUEDA MARTín, M.A., "Cometer un delito por discriminación referente al sexo de la víctima y/o por razones de género como circunstancia agravante genérica», RECPC, Núm. 21, 2019, pp. 24-28.

219 LLORIA GARCÍA, P., «La regulación penal en materia de violencia familiar y de género tras la reforma de 2015. Especial referencia al ámbito tecnológico», Revista General de Derecho Penal, Núm. 31, 2019, p. 12. 
Quizás no se trate tanto de establecer de forma taxativa cuál deba ser la normativa marco que pese más a la hora de interpretar la agravante por motivos discriminatorios de género, si la normativa penal contra los delitos de odio en su vertiente de agravación de delitos comunes (delitos de odio sensu stricto) o la del corpus jurisprudencial construido alrededor de los delitos con marca de género, sino más bien de buscar el sentido práctico y las consecuencias de adoptar una u otra dirección. Lo que quizás no admita lugar a dudas es que, a juzgar por los datos y resultados obtenidos del vaciado jurisprudencial, estamos ante una agravante por motivos discriminatorios de género que representa un híbrido entre los dos mundos de los que proviene. Por una lado su fundamento es, mayoritariamente, subjetivo; más concretamente, según dictados dominantes, se modularía el reproche penal fuera de la antijuridicidad. Por otro lado, los abrumadores datos sobre condenas o confirmaciones de condena harían presagiar, sin tener el más mínimo conocimiento de lo anterior, que la agravante ha pasado a formar una nueva (y más expansiva) herramienta al servicio de los mismos preceptos con marca de género que objetivan la conducta. Dicho de otra forma, el estándar probatorio que requiere el modelo motivacional (demostrar que subyace un ánimo de autor y que éste se haga evidente a través de la intención de someter a la víctima) siempre será más acusado, por lo que una excesiva propensión a apreciar la agravante en los fallos judiciales no entonaría del todo bien con tal fundamento que legitima la agravación. En mi opinión, no se trata tanto de que un modelo u otro (modelo motivacional o modelo de selección discriminatoria) esté siendo decisivo, sino más bien de que se estarían difuminando las fronteras entre ambos mundos mientras aún parece que operan nítidamente respecto a las restantes categorías protegidas (p.ej.: raza, orientación sexual, etc.).

En cualquier caso, la aproximación culpabilística nos aleja de una intepretación que anteponga el daño igual o más gravoso, objetivo y fáctico que se desprende ipso facto de los hechos enjuiciados, siendo así que la cosmovisión machista del acusado deberá acreditarse siempre acudiendo a eventos pasados que refuercen tal hipótesis. De hecho eso es lo que realmente está sucediendo, con el riesgo añadido - y que así reconocen nuestros tribunales- de estar construyendo y sancionando la peligrosidad que dimana de la personalidad de autor ${ }^{220}$, invadiéndose el fuero interno de la persona.

220 Por ejemplo, la STSJ de Castilla y León 8/2018, de 8 de marzo, achaca y critica a la sentencia de primera instancia que la determinación de la personalidad del agresor haya servido para aplicar la agravante por motivos discriminatorios de género (FJ 13). En concreto, atendiendo a la prueba pericial, la sentencia de instancia fijaba cuanto sigue en la relación de hechos probados: «El acusado presenta un patrón de personalidad de tipo narcisista y antisocial, con utilización de estrategias de imposición, explotación y dominación, así como el recurso al uso de violencia en la resolución de problemas inter- 


\section{Referencias bibliográficas:}

Acale SÁnchez, M., Violencia sexual de género contra las mujeres adultas. Especial referencia a los delitos de agresión y abuso sexuales, Reus, Madrid, 2019.

Alonso Álamo, M., "La circunstancia agravante de discriminación», en Díez Ripollés, J.L. (coord.), La ciencia del derecho penal ante el nuevo siglo: libro homenaje al profesor doctor don José Cerezo Mir, Tecnos, Madrid, 2002, pp. 533-542.

Alonso Álamo, M., «El delito de feminicidio. Razones de género y técnica legislativa», en Monge Fernández, A. (dir.)/Parrilla Vergara, J. (coord.), Mujer y derecho penal. ¿Necesidad de una reforma desde una perspectiva de género?, Bosch, Barcelona, 2019, pp. 91-129.

ANGELARI, M., «Hate crime statutes: a promising tool for fighting violence against women", The American University Journal of Gender, Social Policy \& the Law, Vol. 2 (63), 1994, pp. 63-105.

Asua BATARRITA, A., «La razón de género en el marco de la agravante «de odio» del art. 22.4 CP. Por una interpretación restrictiva frente al deslizamiento punitivo», en Pérez Manzano, M./Iglesias Río, M.A./ De Andrés Domínguez, A.C./Martín Lorenzo, M./Valle Mariscal DE GANTE, M. (coords.), Estudios en homenaje a la profesora Susana Huerta Tocildo, Universidad Complutense de Madrid (UCM), Madrid, 2020, pp. 365-376.

Asua Batarrita, A., "Ni impunidad ni punitivismo. Sinrazones de la actual interpretación de la agravante por razón de género del artículo 22.4 del Código Penal», en Otazua Zabala, G./GutiérrezSolana Journoud, A. (dirs.), Justicia en clave feminista. Reflexiones en torno a la inserción de la perspectiva de género en el ámbito judicial, Universidad del País Vasco (UPV/EHU), Bilbao, 2021, pp. 155-184.

BARKer, J./Jurasz, O., Online misogyny as a hate crime. A challenge for legal regulation?, Routledge, London/New York, 2019.

BARry, K., Esclavitud sexual de la mujer, LaSal. Edicions de les dones, Barcelona, 1987.

personales, que suponen importantes desajustes en el ámbito de relación interpersonal, con distorsiones cognitivas sexistas, tendencia a la resolución violenta de problemas, rasgos de personalidad narcisista y antisocial, conducta fría y culpabilización hacia la víctima» (SAP de Segovia 18/2017, de 16 de noviembre, Hechos Probados: Cuarto). La STS 420/2018, de 25 de septiembre, refrendaría la crítica realizada por el STSJ de Castilla y León, aduciendo que es intolerable cualquier suerte de acercamiento al derecho penal de autor y al castigo de las formas de ser de cada quién. Como mucho, llegado el caso, la personalidad cumpliría la función de ser un elemento más al que debe anudarse algún otro para probar la dominación, sometimiento y desprecio de la mujer (FJ 1). 
Bernal del Castillo, J., "Política criminal en España y discriminación xenófoba: la centralidad de los delitos de provocación a la discriminación», Política Criminal: Revista Electrónica Semestral de Políticas Públicas en Materias Penales, Núm. 18, 2014, pp. 371-399.

Boldova Pasamar, M.A., «El actual entendimiento de los delitos de violencia de género y sus perspectivas de expansión", InDret: Revista para el Análisis del Derecho, Núm. 3, 2020, pp. 174-213.

BORJA JiMÉNEZ, E., Violencia y criminalidad racista en Europa occidental: la respuesta del Derecho penal, Comares, Granada, 1999.

Brown, W., States of injury. Power and freedom in late modernity, Princeton University Press, Princeton, 1995.

Brown, W., Estados del agravio. Poder y libertad en la modernidad tardía, Lengua de Trapo, Madrid, 2019.

BRUdHolm, T., "Hate crimes and human rights violations», Journal of Applied Philosophy, Vol. 32 (1), 2015, pp. 82-97.

Brudholm, T., «Conceptualizing hatred globally: is hate crime a human rights violation?», en SchwePpe, J./WALTERs, M.A. (eds.), The globalization of hate. Internationalizing hate crime?, Oxford University Press, Oxford/Nueva York, 2016, pp. 31-48.

Carreras Presencio, A.I., Concepto jurídico de violencia de género, Dykinson, Madrid, 2019.

Díaz López, J.A., El odio discriminatorio como agravante penal. Sentido y alcance del artículo 22.4 ${ }^{a} \mathrm{CP}$, Aranzadi, Pamplona, 2013.

Díaz LóPEZ, J.A., «Una agravante por motivos discriminatorios referidos al género de la víctima», Revista Derecho Penal, Núm. 54, Bogotá, 2016, pp. 5-54.

DíAz LÓPEZ, J.A., «El art. 22.4 CP y la motivación discriminatoria online», en Miró Llinares, F. (dir.), Cometer delitos en 140 caracteres. El Derecho penal ante el odio y la radicalización en Internet, Marcial Pons, Madrid, 2017, pp. 107-127.

DOPICo GÓMEZ-AlLeR, J., «Delitos cometidos por motivos discriminatorios: una aproximación desde los criterios de legitimación de la pena», RGDP, Núm. 4, 2005.

Duff, R.A., The realm of Criminal law, Oxford University Press, Oxford/ Nueva York, 2018.

DufF, R.A./Marshall, S.E., "Criminalizing hate?», en Brudholm, T./ Johansen, B.S. (eds.), Hate, politics, law. Critical perspectives on combating hate, Oxford University Press, Oxford/New York, 2018, pp. 115-149. 
Duggan, M., "Gender and hate crime protections», en AshFord, C./Maine, A. (eds.), Research handbook on gender, sexuality and the law, Edward Elgar Publishing, Cheltenham/Northampton, 2020, pp. 317-329.

Gerstenfeld, P., Hate crimes. Causes, controls and controversies (4th ed.), SAGE, Los Ángeles/Londres, 2017.

Goodall, K., «Conceptualising 'racism' in criminal law», Legal Studies, Vol. 33 (2), 2013, pp. 215-238.

Gordon, I., «El delito de odio como violación de los derechos humanos. Notas destacadas sobre un reciente y desconocido desencuentro académico», en Landa Gorostiza, J.M. (dir.)/Garro Carrera, E. (coord.), Retos emergentes de los derechos humanos: ¿garantías en peligro?, Tirant lo Blanch, Valencia, 2019, pp. 413-433.

GORJÓN BARRANCO, M.C., "Hacia un concepto amplio de violencia de género más allá de la mujer-pareja», en RoIG ToRRES, M., Últimas reformas legales en los delitos de violencia de género. Una perspectiva comparada, Tirant lo Blanch, Valencia, 2018, pp. 53-82.

Hörnle, T., "How to define human dignity, and the resulting implications for biotechnology», en GRIMm, D./KEMMERER, A./ Möllers, C. (eds.), Human dignity in context. Explorations of a contested concept, Nomos, Baden-Baden, 2018, pp. 561-581.

Iganski, P./Sweiry, A., "Hate crime», en Treviño, A.J. (ed.), The Cambridge handbook of social problems (Vol. II), Cambridge University Press, Cambridge/New York, 2018, pp. 399-409.

IgNatiefF, M., El honor del guerrero. Guerra étnica y conciencia moderna, Taurus, Madrid, 1999.

LANDa GoRostiza, J.M., La política criminal contra la xenofobia y las tendencias expansionistas del Derecho penal (a la vez. una propuesta interpretativa de la "normativa antidiscriminatoria» del CP 1995 y un análisis crítico de la incipiente jurisprudencia), Comares, Granada, 2001.

Landa Gorostiza, J.M., Los delitos de odio. Artículos 510 y $22.4^{\circ}$ CP 1995, Tirant lo Blanch, Valencia, 2018.

Larrauri Pijoan, E., Criminología crítica y violencia de género $\left(2^{a}\right.$ ed.), Trotta, Madrid, 2018.

Laurenzo Copello, P., «La discriminación en el Código penal de 1995», Estudios penales y criminológicos, Núm. 19, 1996, pp. 219-288.

Laurenzo Copello, P., "¿Hacen falta figuras género específicas para proteger mejor a las mujeres?», Estudios penales y criminológicos, Núm. 35, 2015, pp. 783-830.

Laurenzo Copello, P., «Un ejemplo de derecho penal expansivo: los delitos de odio en la realidad judicial española», Revista de Derecho Penal, Núm. 26, 2018, pp. 243-255. 
Laurenzo Copello, P., «La manipulación de los delitos de odio», en Portilla Contreras, G./Velásouez Velásquez, F. (dirs.), Un juez para la democracia: libro homenaje a Perfecto Andrés Ibáñez, Dykinson, Madrid, 2019, pp. 453-468.

Lawrence, F.M., Punishing hate. Bias crimes under American law, Harvard University Press, Cambridge, 1999.

Leng, R./Taylor, R.D./WasiK, M., Blackstone's guide to the Crime and Disorder Act 1998, Blackstone Press, Londres, 1998.

LLORIA GARCÍA, P., «La regulación penal en materia de violencia familiar y de género tras la reforma de 2015. Especial referencia al ámbito tecnológico», Revista General de Derecho Penal, Núm. 31, 2019.

Magro SERVET, V., Manual práctico sobre agravantes y subtipos agravados en el Código penal, La Ley, Madrid, 2019.

Magro Servet, V., Guía práctica penal de delitos de violencia de género, La Ley, Madrid, 2020.

Maher, J.M./McCulloch, J./Mason, G., «Punishing gendered violence as hate crime: aggravated sentences as a means of recognising hate as motivation for violent crimes against women", Australian Feminist Law Journal, Vol. 41 (1), 2015, pp. 177-193.

Maqueda Abreu, M.L., «El hábito de legislar sin ton ni son. Una lectura feminista de la reforma penal de 2015», Cuadernos de Politica Criminal, Núm. 118, 2016, pp. 5-42.

Maqueda Abreu, M.L., "¿Necesitan un móvil discriminatorio las agravantes de sexo/género del art. 22.4 CP?», en Silva SÁNCHEZ, J.M./ Castiñeira Palou, M.T./Corcoy Bidasolo, M./Queralt Jiménez, J.J. (coords.), Estudios de Derecho penal: homenaje al profesor Santiago Mir Puig, B de F, Buenos Aires, 2017, pp. 703-714.

Marín De Espinosa Ceballos, E.B., «La agravante genérica de discriminación por razones de género (art. 22.4 CP)», en MoRALES Prats, F./Tamarit Sumalla, J.M./García Albero, R. (coords.), Represión penal y Estado de derecho. Homenaje al Profesor Gonzalo Quintero Olivares, Aranzadi, Pamplona, 2018, pp. 409-424.

Marín De Espinosa Ceballos, E.B., «La agravante genérica de discriminación por razones de género (art. 22.4 CP)», RECPC, Núm. 20, 2018.

Mason, G./Dyer, A., "'A negation of Australia's fundamental values': sentencing prejudice-motivated crime», Melbourne University Law Review, Vol. 36, 2013, pp. 871-914.

McPhaIL, B.A., «Gender-bias hate crimes. A review», Trauma, violence \& abuse: SAGE journals, Vol. 3, 2002, pp. 125-143. 
McPhaIL, B.A./DiNitTo, D.M., "Prosecutorial perspectives on gender-bias hate crimes», Violence against women, Vol. 11 (9), 2005, pp. 11621185.

OReJón SÁNCHez de las HeRAs, N., La circunstancia agravante genérica de discriminación por razones de género, Iustel, Madrid, 2019.

PentTinen, E., «Gender agency and violence», en Gentry, C.E./ShePherd, L.J./SJOBERG, L. (eds.), The Routledge handbook of gender and security, Routledge, Londres/Nueva York, 2019, pp. 252-261.

Pérez Manzano, M., «En busca de la identidad del feminicidio de la pareja o expareja: entre el odio y la discriminación», $A D P C P$, Vol. 71, 2018, pp. 91-120.

PERRY, B., In the name of hate. Understanding hate crimes, Routledge, Nueva York/Londres, 2001.

Perry, B./Olsson, P., «Hate crime as a human rights violation», en Perry, B./Iganski, P. (eds.), Hate crime (Vol. 2). The consequences of hate crime, Praeger (ABC-CLIO), Westport/London, 2009, pp. 175-191.

Prats Canut, J.M., «Comentario al art. 22.4 CP: cometer el delito por racismo o xenofobia», en Quintero Olivares, G. (dir.), Comentarios al Código penal. Tomo I. Parte general (artículos 1 a 137) (5 a ed.), Thomson Reuters Aranzadi, Cizur Menor, 2008.

Presno Linera, M.A., «El discurso del odio contra las minorías sexuales: respuestas penales y administrativas», en Matia Portilla, F.J./ElviRA Perales, A./Arroyo Gil, A. (dirs.), La protección de los derechos fundamentales de personas LGTBI, Tirant lo Blanch, Valencia, 2019, pp. 279-312.

REBOLlo VARGAS, R., «Controversias y propuestas interpretativas sobre la agravante de discriminación por razón de odio», en LANDA GOROSTIZA, J.M./Garro Carrera, E. (coords.), Delitos de odio. Derecho comparado y regulación española, Tirant lo Blanch, Valencia, 2018, pp. 195-220.

Rodríguez Devesa, J.M./Serrano Gómez, A., Derecho penal español. Parte general (18 ed.), Dykinson, Madrid, 1995.

RUEDa MARTín, M.A., La violencia sobre la mujer en su relación de pareja con un hombre. Análisis doctrinal y jurisprudencial, Reus, Madrid, 2012.

Rueda Martín, M.A., «Cometer un delito por discriminación referente al sexo de la víctima y/o por razones de género como circunstancia agravante genérica», RECPC, Núm. 21, 2019.

Salinero Alonso, C., Teoría general de las circunstancias modificativas de la responsabilidad criminal y artículo 66 del Código penal, Comares, Granada, 2000.

Santana Vega, D.M., «El tratamiento penal de la discriminación por razón de orientación o identidad sexuales», en CuEsta LóPEZ, V./ 
Santana Vega, D.M. (dirs.), Estado de Derecho y discriminación por razón de género, orientación e identidad sexual, Aranzadi/Universidad de las Palmas de Gran Canaria, Cizur Menor/Las Palmas de Gran Canaria, 2014, pp. 383-420.

Sanz Mulas, N., Violencia de género y pacto de estado. La huida hacia adelante de una norma agotada (LO 1/2004), Tirant lo Blanch, Valencia, 2019.

StEARns, E., «Hate and gender», en Valeri, R.M./Borgeson, K. (eds.), Hate crimes. Typology, motivations, and victims, Carolina Academic Press, Durham, 2018, pp. 167-192.

TAmarit Sumalla, J.M., «¿Cuándo la violencia es de género?: ley, ciencia y política en la jurisprudencia», en TAMARIT Sumalla, J.M./PEREDA Beltran, N. (coords.), Violencia de género en las relaciones de pareja, Marcial Pons, Madrid, 2020, pp. 21-43.

TAPia Ballesteros, P., «Identificación de las víctimas de los delitos de odio: aproximación a algunos de los problemas que plantea esta categoría delictiva», en De Hoyos SANCHO, M. (dir.), La víctima del delito y las últimas reformas procesales penales, Aranzadi, Pamplona, 2017, pp. 355-371.

VidALES Rodríguez, C., «La generalización del género: reflexiones en torno a la agravante de discriminación por razón de género», Revista General de Derecho Penal, Núm. 32, 2019.

Villacampa Estiarte, C., «El maltrato singular cualificado por razón de género. Debate acerca de su constitucionalidad», RECPC, Núm. 9, 2007.

Villacampa Estiarte, C., "Pacto de estado en materia de violencia de género: ¿más de lo mismo?», RECPC, Núm. 20, 2018.

Villacampa Estiarte, C., Política criminal española en materia de violencia de género. Valoración crítica, Tirant lo Blanch, Valencia, 2018.

Walters, M.A./Tumath, J., "Gender 'hostility', rape, and the hate crime paradigm», The modern law review, Vol. 77 (4), 2014, pp. 563-596.

Zapater Ferrer, J.J., La circunstancia de desprecio de sexo en la jurisprudencia del Tribunal Supremo, Universidad de Valencia, Valencia, 1980.

\section{Otras fuentes}

CGPJ, Análisis de la aplicación de la agravante por razón de género en las sentencias dictadas entre 2016 y mayo de 2018, CGPJ, Madrid, 2018, http://www.poderjudicial.es/cgpj/es/Temas/Violencia-domestica-y-degenero/Grupos-de-expertos/Analisis-aplicacion-de-la-agravante-por- 
razon-de-genero-en-sentencias-dictadas-entre-2016-y-mayo-de-2018 (último acceso: 13/09/2020).

DíAz LóPez, J.A., Informe de delimitación conceptual en materia de delitos de odio, Secretaría General de Inmigración y Emigración, Observatorio Español del Racismo y la Xenofobia, Madrid, 2018, http://www.inclusion.gob.es/oberaxe/ficheros/documentos/ InformeConceptualDelitosOdio.pdf (último acceso: 13/09/2020).

Fiscalía General del Estado, Circular 1/1998, de 24 de octubre, sobre la intervención del Ministerio Fiscal en la persecución de los malos tratos en el ámbito doméstico y familiar, FGE, Madrid, 1998, https:// www.fiscal.es/memorias/estudio2016/CIR/CIR_01_1998.html (último acceso: 13/09/2020).

Fiscalía General del Estado, Circular 7/2019, sobre pautas para interpretar los delitos de odio tipificados en el art. 510 CP, FGE, Madrid, 2019, https://www.fiscal.es/documents/20142/f42d355a-ce0b-3652-562c53fe07d6ccc6 (último acceso: 13/09/2020).

LANDA Gorostiza, J.M., «El delito de odio del artículo 510 CP: propuesta de interpretación después de la reforma de 2015», Ponencia enmarcada en la segunda jornada (sesión de mañana) del Simposio Internacional sobre "Delitos de odio: estado de la cuestión desde una perspectiva comparada», Bilbao (Bizkaia Aretoa), 22 de septiembre de 2017.

OSCE/ODIHR, Combating hate crimes in the OSCE region, OSCE/ODIHR, Varsovia, 2005, https://www.osce.org/files/f/documents/2/3/16405.pdf (último acceso: 13/09/2020).

OSCE/ODIHR, Decisión del Consejo Ministerial de la OSCE núm. 15/2005 sobre la prevención y combate de la violencia contra la mujer, de 6 de diciembre de 2005 (MC.DEC/15/05), OSCE/ODIHR, Liubliana, 2005, https://www.osce.org/files/f/documents/b/7/70204.pdf (último acceso: 13/09/2020).

OSCE/ODIHR, Hate crime laws. A practical guide, OSCE/ODIHR, Varsovia, 2009, https://www.osce.org/files/f/documents/3/e/36426.pdf (último acceso: 13/09/2020).

OSCE/ODIHR, Prosecuting hate crimes. A practical guide, OSCE/ODIHR, Varsovia, 2014, https://www.osce.org/files/f/documents/0/0/124532.pdf (último acceso: 13/09/2020).

OSCE/ODIHR, La persecución penal de los delitos de odio. Guía práctica, Ministerio de Empleo y Seguridad Social. Subdirección General de Información Administrativa y Publicaciones, Madrid, 2016, https:// cpage.mpr.gob.es/producto/la-persecucion-penal-de-los-delitos-deodio-2/ (último acceso: 13/09/2020). 
